\title{
WATER RESOURCES OF UPPER SEPARATION CREEK BASIN, SOUTH-CENTRAL WYOMING
}

U.S. GEOLOGICAL SURVEY

Water-Resources Investigations $80-85$
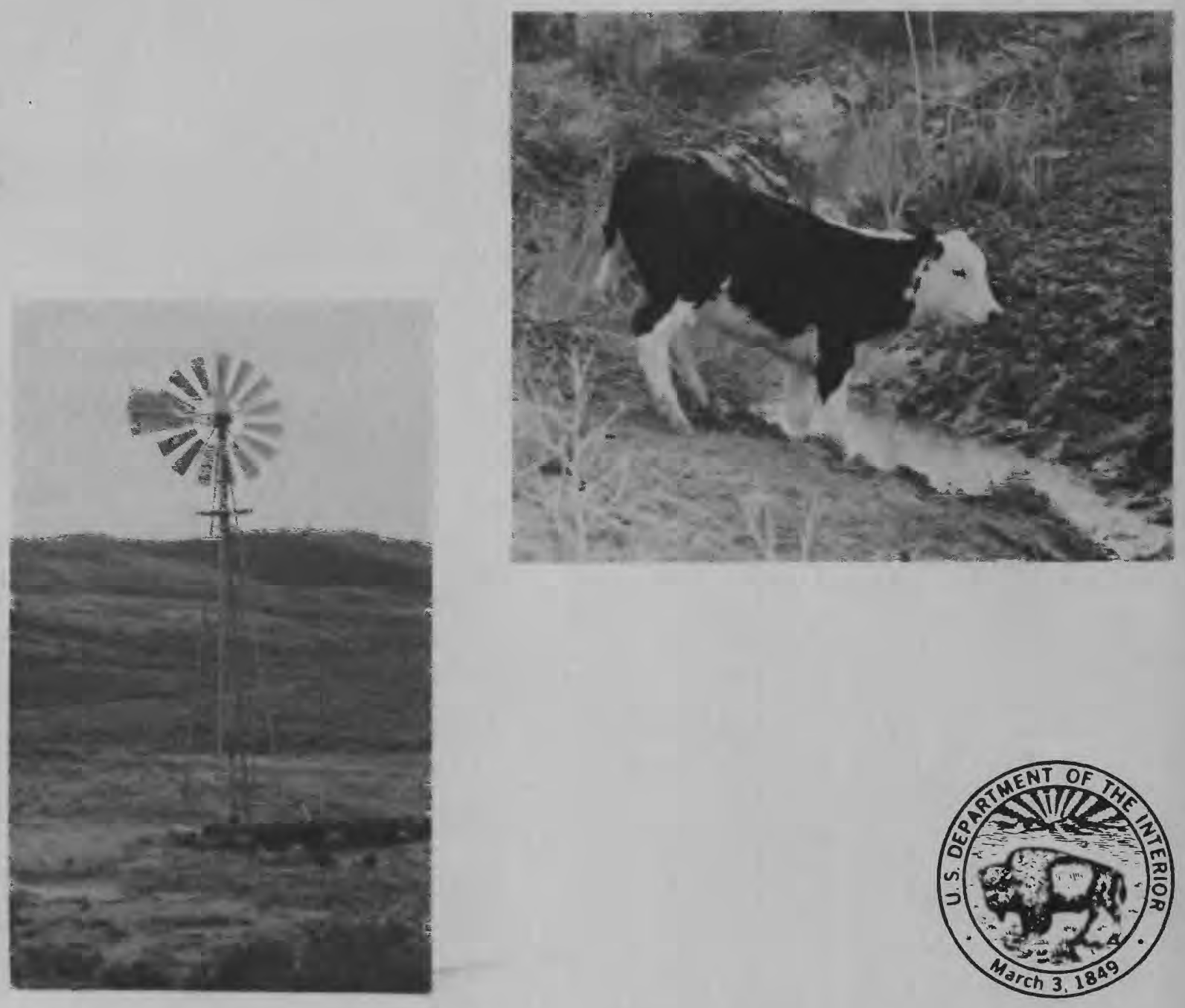


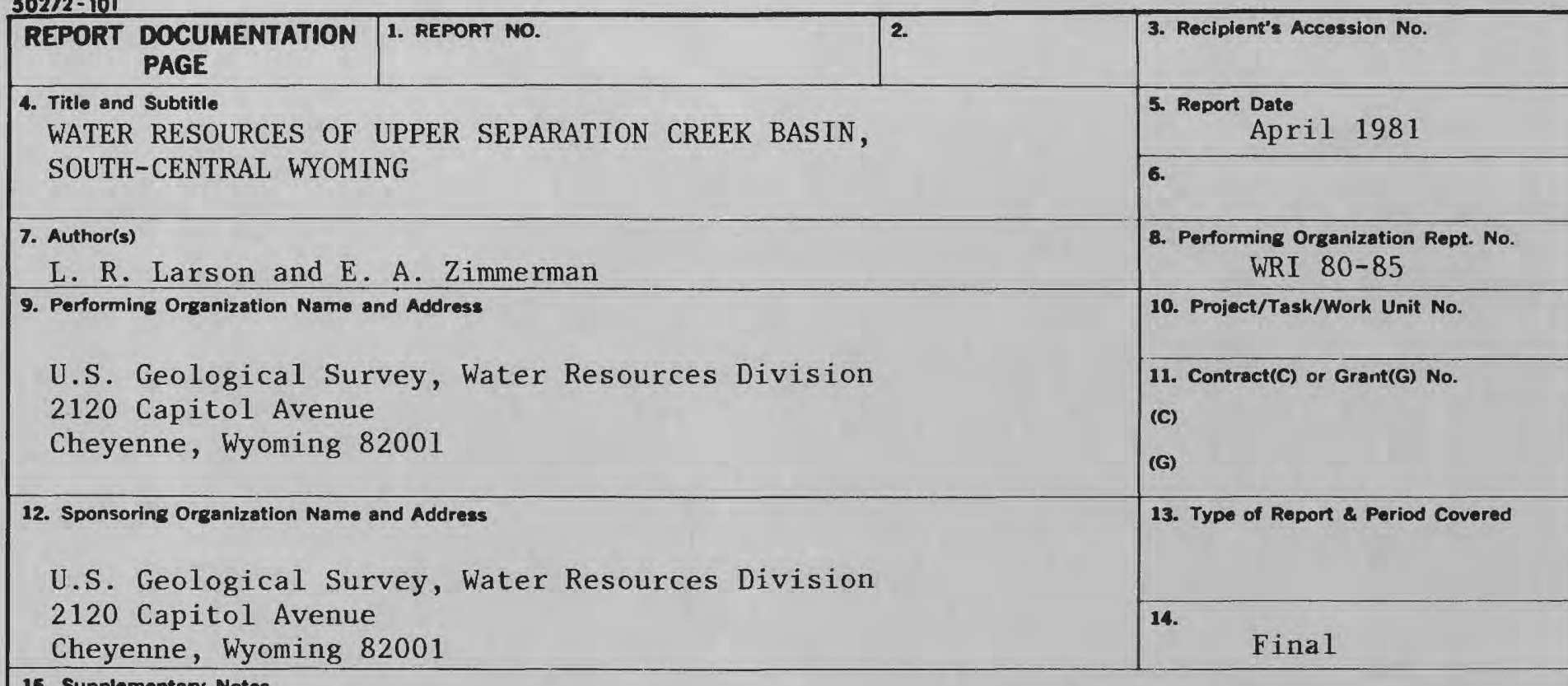

15. Supplementary Notes

\section{Abstract (Limit: 200 words)}

The water resources of the small basin ( 85 square miles) were examined before the expected start of large-scale coal mining. Streamflow was intermittent, resulting primarily from snowmelt and rainstorms. Average annual runoff was estimated at 2,500 acre-feet. The 1976 runoff was 2,040 acre-feet. The near absence of snowpack in 1977 resulted in greatly reduced runoff, less than 200 acre-feet. Ground water is obtainable from the Mesaverde Formation, the Lance and Fort Union Formations, and from alluvium. Yields from most wells and springs are less than 10 gallons per minute. Dissolvedsolids concentrations in Separation Creek ranged from less than 100 to more than 1,500 milligrams per liter during 1976. Daily mean sediment concentration ranged from 34 to 11,900 milligrams per liter. Stream biota was limited by the intermittent nature of the streamflow and by stream habitat. Ground-water quality varied with the formation Both ground water and surface water are generally well suited for their present use as stock water.

17. Document Analysis a. Descriptors

*Aquifers, *streamflow, *water quality, water resources, watershed (basin), ground water, springs, wells, aquifer characteristics, hydrology, snowmelt, source, drought, dissolved-solids concentration, sediment, biological community, dominant organisms, water temperatures.

b. Identifiers/Open-Ended Terms

Flushing, upper Separation Creek, Wyoming

c. COSATI FIeld/Group

18. Availability Statemen:

No restriction on distribution

19. Security Class (This Report)

20. Security Class (This Page)
21. No. of Pages

22. Price 
WATER RESOURCES OF UPPER SEPARATION

CREEK BASIN, SOUTH-CENTRAL WYOMING

By L. R. Larson and Everett A. Zimmerman

U. S. GEOLOGICAL SURVEY

Water-Resources Investigations 80-85

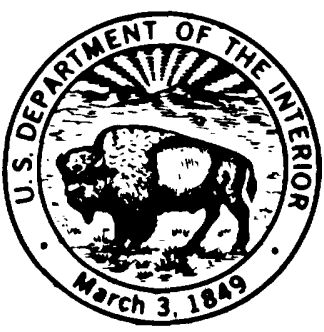


UNITED STATES DEPARTMENT OF THE INTERIOR

JAMES G. WATT, Secretary

GEOLOGICAL SURVEY

Doyle G. Frederick, Acting Director

For additional information write to:

District Chief

U.S. Geological Survey

P. 0. Box 1125

Cheyenne, Wyoming 82001 
Abstract-1-0

Introduction-

Description of the problem-

Purpose and scope--

Previous investigations-

Acknowledgments--

Units of measurement and vertical datum-

Site identification--

Description of the study area-

Location-1.-

Topography-10.-

Geology-10.-

Climate--0.-10

Vegetation-10

Streamflow-10

Ground-water availability-

Water quality-

Surface-water quality-

Dissolved-solids concentration-

pH-1.-

Dissolved oxygen-1

Trace metals and radioactive substances-

Suspended sediment--

Biota-c-

Temperature-1- 55

Ground-water quality- 57

Summary and conclusions-1 67

References cited-1 68

\section{ILLUSTRATIONS}

Figure 1. Diagram showing how township, range, and section numbers are combined to designate

a site number-

2-4. Maps showing

2. Separation Creek in south-central Wyoming

flows from the head of Jep Canyon and

breaches several ridges before crossing

Interstate Highway 80

3. Sedimentary rocks, from the Steele Shale to the Fort Union Formation, underlie the study area-

4. Sedimentary rocks, from the Steele Shale to the
Fort Union Formation, dip steeply to the west-northwest across the upper Separation

Creek basin-...

5. Photograph of the basal sandstone of the Fort Union Formation that forms the topographically prominent Red Rim- 
Figures 6-8. Graphs showing

6. Extreme temperatures observed at Rawlins, Wyoming, range from $-36^{\circ} \mathrm{F}\left(-38^{\circ} \mathrm{C}\right)$ to more than $100^{\circ} \mathrm{F}\left(38^{\circ} \mathrm{C}\right)$, though mean monthly temperatures range from $21^{\circ} \mathrm{F}\left(-6^{\circ} \mathrm{C}\right)$ to $68^{\circ} \mathrm{F}\left(20^{\circ} \mathrm{C}\right)$

7. The average monthly precipitation at Rawlins (1931-60) ranges from about 0.5 inch during November to more than 1.4 inches during May-

8. Potential monthly evapotranspiration during the growing season is about 6.5 inches during July

9. Map showing location of stream-sampling sites

in upper Separation Creek drainage--
10. Hydrographs of upper Separation Creek for 1976 and 1977 water years at site S-29 show a greatly reduced runoff during 1977-

11. Photographs taken March 29, 1976, show the contrast between the heavy snowpack in Jep Canyon at 7,800 feet and the snowpack around site S-29 at 6,800 feet-...

12. Graph showing a synoptic comparison of streamflow at the near-normal discharge of May 1976 and of May 1977

13. Photograph of a dry beaver pond in the stream channel during May 1977 illustrates the lack of snowpack runoff in Jep Canyon upstream from site S-6

14-16. Maps showing

14. Location of selected ground-water sites in the study area-

15. Well and spring locations and approximate potentiometric surface of water in the Mesaverde Formation-

16. Well locations and approximate potentiometric surface of water in the Fort Union Formation

17-22. Graphs showing

17. Specific conductance can be used to estimate the dissolved-solids concentration of upper Separation Creek-1

18. Daily specific conductances at site S-29 during 1976 and 1977 water years show an increase in specific conductance and dissolved-solids concentration during the 1977 runoff-

19. Effects of rainfall on stream discharge and specific conductance at site S-29 during June 1976-

comparison of specific conductance for upper Separation Creek between May 1976 and May 1977 shows an increase in specific conductance during May 1977- 
Figures 17-22. Graphs showing--Continued

Page

21. Areal and temporal variations of specific conductance, discharge, $\mathrm{pH}$, and dissolved oxygen for upper

Separation Creek-

22. Cumulative ionic composition of water during high- and low-flow

conditions of upper Separation Creek

23. Histogram showing the $\mathrm{pH}$ values measured

during 1975 and 1976 ranged from 7.3 to 9.1

24. Histogram showing dissolved-oxygen concentrations

measured during 1975 and 1976 ranged from 5 to

15 milligrams per liter

25-29. Graphs showing

25. Daily discharge, suspended-sediment

concentration, and suspended-sediment

load at site S-29 during 1976 water year-..........

26. The suspended-sediment load may be predicted from the snowmelt-induced

discharge at site $\mathrm{S-29}$

27. Relative abundance of phytoplankton in upper Separation Creek, May 12-13, 1976-_.-.

28. Harmonic model of water temperature for upper Separation Creek at site $\mathrm{S}-29$ shows a relation with the measured mean daily water temperature

29. Relation of elevation of sampling station to annual harmonic-mean water temperature for streams in the Green River and Great Divide Basins of Wyoming-

30. Stiff diagrams aid comparison of chemical analyses of water samples from alluvium and the Fort Union Formation-

31. Stiff diagrams aid comparison of chemical analyses of water samples from the Fort Union Formation, Lewis Shale, and

Mesaverde Formation-

\section{TABLES}

Table 1. Wells and springs in the upper

Separation Creek basin-

2. Guide to the use of saline waters for livestock

and poultry- 30

3. Surface-water chemical analyses-_. 42

4. Surface-water trace-metal analyses-_. 47

5. Surface-water radiochemical analyses-a 48

6. Periphyton and phytoplankton 1 ist by genera- 53

7. Benthic invertebrates by family 54

8. Ground-water chemical analyses-a 61

9. Ground-water trace-metal analyses-_. 65

10. Ground-water radiochemical analyses... 66 
WATER RESOURCES OF UPPER SEPARATION CREEK BASIN,

SOUTH-CENTRAL WYOMING

By L. R. Larson and Everett A. Zimmerman

\section{ABSTRACT}

Upper Separation Creek basin is an area of 85 square miles in southcentral Wyoming where uses of land have been mainly for grazing of livestock, hunting, and exploring for oil and gas. Development of proposed coal mines within the basin will greatly change the uses of land and the demand for water in the basin and adjoining areas.

Surface-water availability is seasonal and variable in quantity, with snowmelt providing most of the streamflow. Streamflow in the downstream reaches generally begins during early spring and ceases during the summer, shortly after the last snowdrifts have disappeared in the upper basin. Runoff at a streamflow gaging station near the lower end of the basin was 2,040 acre-feet during the 1976 water year but only 190 acre-feet during the 1977 water year. Reduced runoff during the 1977 water year was due to the reduced snowpack during the winter of 1976-77. An average annual runoff of 2,500 acre-feet was estimated for the southern 55-square-mile area of the basin upstream from the gaging station.

The dissolved-solids concentration is the most critical factor affecting streamflow quality. Dissolved-solids concentration at the gaging station during the 1976 water year ranged from less than 100 to more than 1,500 milligrams per liter. The decreased runoff during the 1977 water year resulted in increased water salinity. The estimated mean dissolved-solids concentration for the 1977 runoff period was twice as great as the estimated 700 milligrams per liter for the 1976 runoff period.

Flushing of salts that have accumulated in the stream channel occurs during a rising stage. The flushing action is further increased as rainfall runoff leaches salts from the basin soils. A rainstorm during June 1976 temporarily increased streamflow fourfold and doubled the dissolved-solids concentration.

Suspended-sediment yield for the 55-square-mile basin upstream from the gaging station was 902 tons for the 1976 water year. Daily mean sediment concentrations for the same year ranged from 34 to 11,900 milligrams per liter.

Stream habitat and environmental stability are key factors that affect the aquatic biota. The intermittent nature of the streamflow limits the stream biota to organisms capable of aestivating or producing a resting spore; otherwise, the organisms must survive in springs or beaver ponds that do not dry up. Blue-green algae, Anabaena, proliferate in pools remaining after streamflow has ceased during the summer. 
Daily mean water temperatures in the stream closely approximates the daily mean air temperatures and can be predicted. A difference of 1,800 feet in elevation would account for a $3.5^{\circ} \mathrm{C}$ difference in mean temperature between the headwaters and the downstream reach of Separation Creek in the study area.

Ground water, the most reliable source of water in the basin, is available from the Mesaverde Formation, the Lance and Fort Union Formations, and alluvium. The Mesaverde yields about 4 gallons per minute apiece to many small springs on the flanks of the Atlantic Rim. Most stock wells completed in the Lance and Fort Union yield as much as 10 gallons per minute, but one well completed in the basal sandstone of the Fort Union west of the basin yields more than 300 gallons per minute. The Fort Union Formation underlies much of the study area and contains much of the coal to be mined. Ground water in the formation can provide for the needs of the mining operation but also may necessitate dewatering of excavations. Only test holes have been completed in the alluvium; however, it is important as a regulating reservoir for Separation Creek whose flow is sustained for short reaches by discharge from the alluvium.

Ground water generally is of a quality suitable for use by livestock, although water from one spring in the Lewis Shale had a dissolved-solids concentration of 57,700 milligrams per liter, and water from the basal alluvium had a dissolved-solids concentration of 10,300 milligrams per liter. Much of the ground water would be considered unsuitable for domestic use because of the relatively large iron, manganese, and sulfate concentrations.

\section{INTRODUCTION}

This report describes the hydrology of a small basin in south-central Wyoming. Previous studies have largely ignored similar small basins because: (1) Their small size and the ephemeral or intermittent streamflow in these basins produced relatively small amounts of runoff, and (2) the activities of ranching, oil or gas exploration, and hunting had little effect on the hydrologic system.

\section{Description of the Problem}

Coal mining will soon increase the activities of man in the upper Separation Creek basin. Hydrologic data will be needed to formulate mining plans and to minimize undesirable environmental impacts.

\section{Purpose and Scope}

The purposes of this report are: (1) To describe the water resources of the basin before mining begins, and (2) to describe the principal stresses that affect both quantity and quality of water available. Because surface-water quantity and quality are both variable, emphasis is placed on describing their temporal and areal variations. The hydrologic data will contribute to mining plans. Hydrologic data collected before mining will enable quantitative measurements of the effects of mining on the hydrologic system.

Data collection began during the summer of 1975 and is continuing (1980). Ground-water and surface-water data collected through September 1977 and sediment data through 1976 are included in this report. 


\section{Previous Investigations}

Much of the data in this report is from the U.S. Geological Survey's contribution to the U.S. Bureau of Land Management's EMRIA (Energy Minerals Resource Inventory and Analysis) report (1976). Some geologic data are from earlier reports by Welder and McGreevy (1966), Bradley (1961), and Sanders (1974). Richard W. Davis (written commun., 1976) prepared a consultant's report for Rocky Mountain Energy Co. Berry (1960) described the geology and ground-water resources of the Rawlins area.

\section{Acknowledgments}

The cooperation received from Steve Sun and John Hansen, local ranchers, in supplying historical data and granting access to private land is gratefully acknowledged. Rocky Mountain Energy Co. permitted access to their test wells and provided data on them, through both written reports and contact with their consultant, Richard W. Davis.

\section{Units of Measurement and Vertical Datum}

Distances and discharges in this report are in inch-pound units, whereas water temperatures and chemical concentrations are in metric units. Air temperature is, by convention, in degrees Fahrenheit. Concentrations are expressed in milligrams per liter $(\mathrm{mg} / \mathrm{L})$ or micrograms per 1 iter $(\mu \mathrm{g} / \mathrm{L})$. Assuming a density of 1.0 for the water analyzed, milligrams per liter are equivalent to parts per million (ppm) and micrograms per liter are equivalent to parts per billion (ppb).

The following factors may be used to convert the inch-pound units of measurement used in this report to the International System of Units (SI) or metric units:

$\begin{array}{lll}\text { Multiply } & \text { By } & \text { To obtain } \\ & \text { Length } & \\ \text { inch } & 25.4 & \text { millimeter } \\ \text { foot } & 0.3048 & \text { meter } \\ \text { mile } & 1.609 & \text { kilometer } \\ & \text { Area } & \\ \text { acre } & 0.4047 & \text { hectare } \\ \text { square mile } & 2.590 & \text { square kilometer } \\ & \text { Volume } & \text { cubic meter } \\ \text { acre-foot } & 1,233 & \\ & \text { Discharge } & \text { liter per second } \\ \text { cubic foot per } & 28.32 & \text { liter per second } \\ \text { second (ft } 3 / \mathrm{s}) & 0.06309 & \text { megagram } \\ \text { gallon per minute (gal/min) } & \text { Mass } & \text { megagram per square kilometer } \\ \text { ton, short }(2,000 \text { pounds) } & 0.9072 & \text { degree Celsius }\left({ }^{\circ} \mathrm{C}\right) \\ \text { ton per square mile } & 0.3503 & \text { Temperature } \\ \left.\text { degree Fahrenheit ( }{ }^{\circ} \mathrm{F}\right) & \left({ }^{\circ} \mathrm{F}-32\right) \quad 5 / 9 & \end{array}$


1 cubic foot per day per foot $\left[\left(f t^{3} / d\right) / f t\right]$

or

2 foot squared per day $\left(f t^{2} / d\right.$ or $\mathrm{ft}^{2} \mathrm{~d}^{-1}$ )

1 expanded form

2 reduced form cubic meter per day

per meter

or

meter squared per day per meter

National Geodetic Vertical Datum of 1929 is a geodetic datum derived from a general adjustment of the first-order level nets of both the United States and Canada, formerly called "Mean Sea Level."

\section{Site Identification}

The identification number used by the U.S. Geological Survey for ground-water and miscellaneous surface-water sites is a 15-digit number which represents the latitude, longitude, and sequence number of the site. The first six digits represent the latitude, the next seven digits, the longitude, and the last two digits, the sequence number. Station 413731107311001 thus represents a site at latitude $41^{\circ} 37^{\prime} 31^{\prime \prime} \mathrm{N}$., and longitude $107^{\circ} 31^{\prime} 10^{\prime \prime} \mathrm{W}$., which has been assigned a sequence number of 01 . The sequence number allows the designation of as many as 99 sites in an area which is defined by a second of latitude and longitude.

An eight-digit station identification number is used by the U.S. Geological Survey in designating a surface-water station which has been assigned a downstream order number. Two sites in this report, stations 09216525 and 09216527, have such numbers. The first two digits indicate the major drainage basin in which the site is located. The 09 in these numbers indicates the stations are in the Green River or Great Divide Basins. In a given basin an increase in station number indicates that the sites are downstream from smaller numbers. Stations on a tributary will have smaller numbers than any site downstream.

In this report, for the reader's convenience, surface-water sites also are given a simplified downstream order number. Surface-water sites are designated by the letter " $S$ " followed by a number which indicates the distance the site is downstream from the stream divide as measured along the stream channe1. Thus "S-14" indicates a surface-water site 14 miles downstream from the stream divide. 
Wells and springs are identified by a number based on the Federal system of land subdivision (fig. 1). The first number indicates the township, the second the range, and the third the section in which the well or spring is located. The section number is followed by three letters, the first letter indicating the quarter section, the second the quarter-quarter section, and the third the quarter-quarter-quarter section. The subdivisions of a section are lettered $A, B, C$, or $D$ in a counterclockwise direction starting in the northeast quarter. This system locates the site in a 10-acre area. A two-digit sequence number following the letters allows designation of 99 wells or springs within the 10 acres defined by the rest of the number. For example,

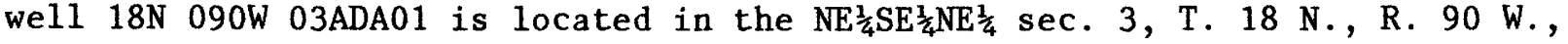
as shown in figure 1 . The 01 sequence number indicates it was the first well assigned a number in this 10-acre tract.

\section{DESCRIPTION OF THE STUDY AREA}

\section{Location}

The study area is in south-central Wyoming and comprises the 85 square miles of Separation Creek basin that occur south of Interstate Highway 80 (fig. 2). This area is referred to as the upper Separation Creek basin in this report. The nearest town is Rawlins, about 7 miles east.

\section{Topography}

Elevations in the upper Separation Creek basin range from about 6,650 feet to more than 8,400 feet. The topography of the basin and surrounding area is shown in figure 2. Separation Creek heads in Jep Canyon, flows unt of the canyon into a valley bordered by rolling hills, then flows northeastward parallel to the dominant ridges for about 5 miles. The creek then turns abruptly westward and cuts across sandstone and shale in a tortuous, incised channel to beyond the Red Rim. Farther downstream it resumes a northeastward course in a widening valley but with a shallower and braided channel. In the 4 miles immediately upstream from Interstate Highway 80 , the creek crosses a wide meadow in several shallow channels.

Three major northeast-trending ridges dominate the topography of upper Separation Creek basin. The highest is the Atlantic Rim, divided into two ridges by Jep Canyon. The next ridge to the northwest is Hogback Ridge and the northwesternmost is the Red Rim.

\section{$\underline{\text { Geology }}$}

Geologic units of interest range from Late Cretaceous to Holocene in age in the upper Separation Creek basin. In ascending order, these units are the Steele Shale, Mesaverde Formation, Lewis Shale, and Lance Formation of Late Cretaceous age, the Fort Union Formation of Paleocene age, and the alluvium and colluvium of Holocene age. The distribution of these formations (except for alluvium and colluvium) is shown on the geologic map (fig. 3), and the vertical relationships are shown on the geologic section (fig. 4). The Steele Shale is not described because it is not important as a source of water and does not crop out in the basin. 


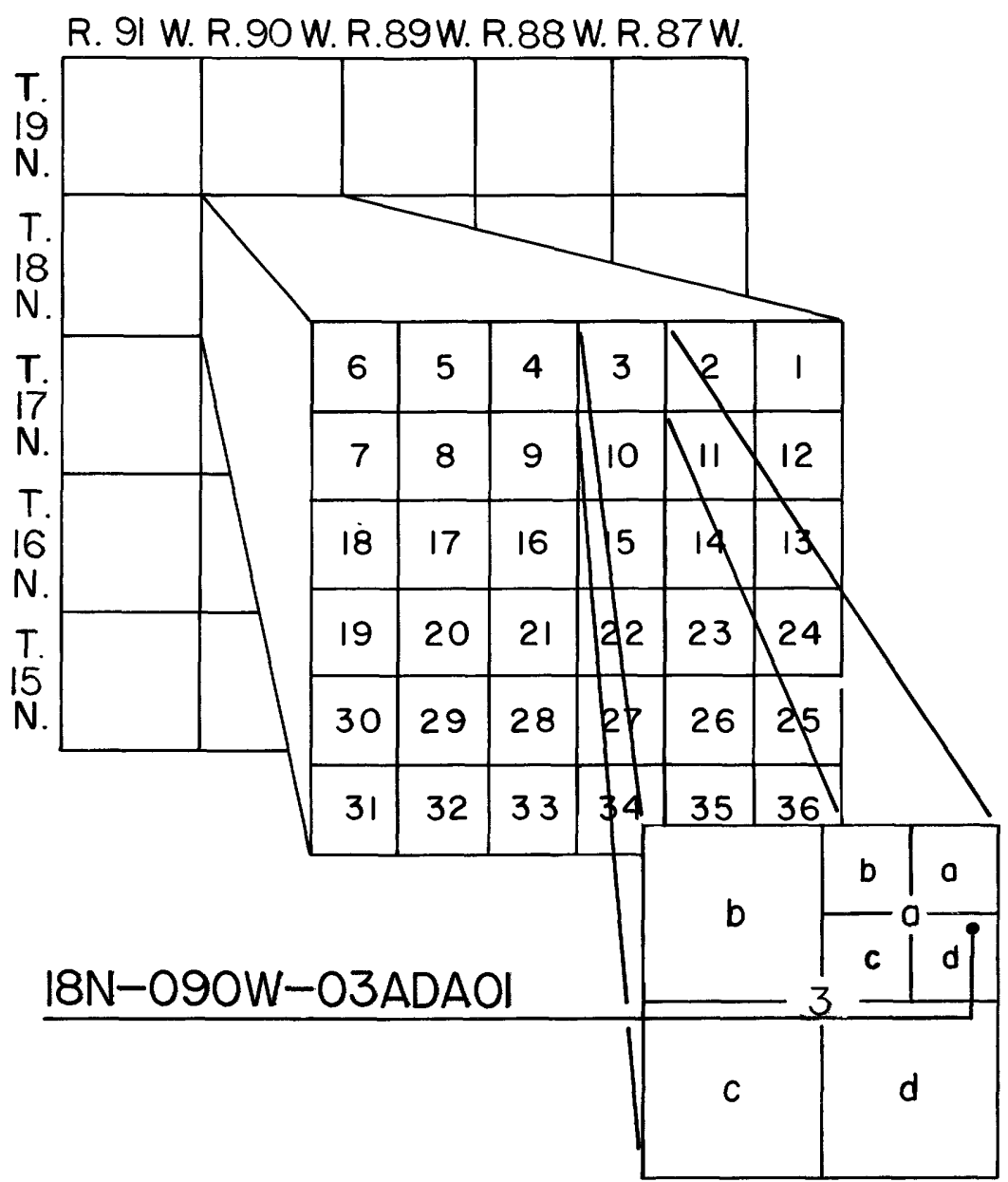

Figure 1.--Township, range, and section numbers may be combined to designate a site number. 


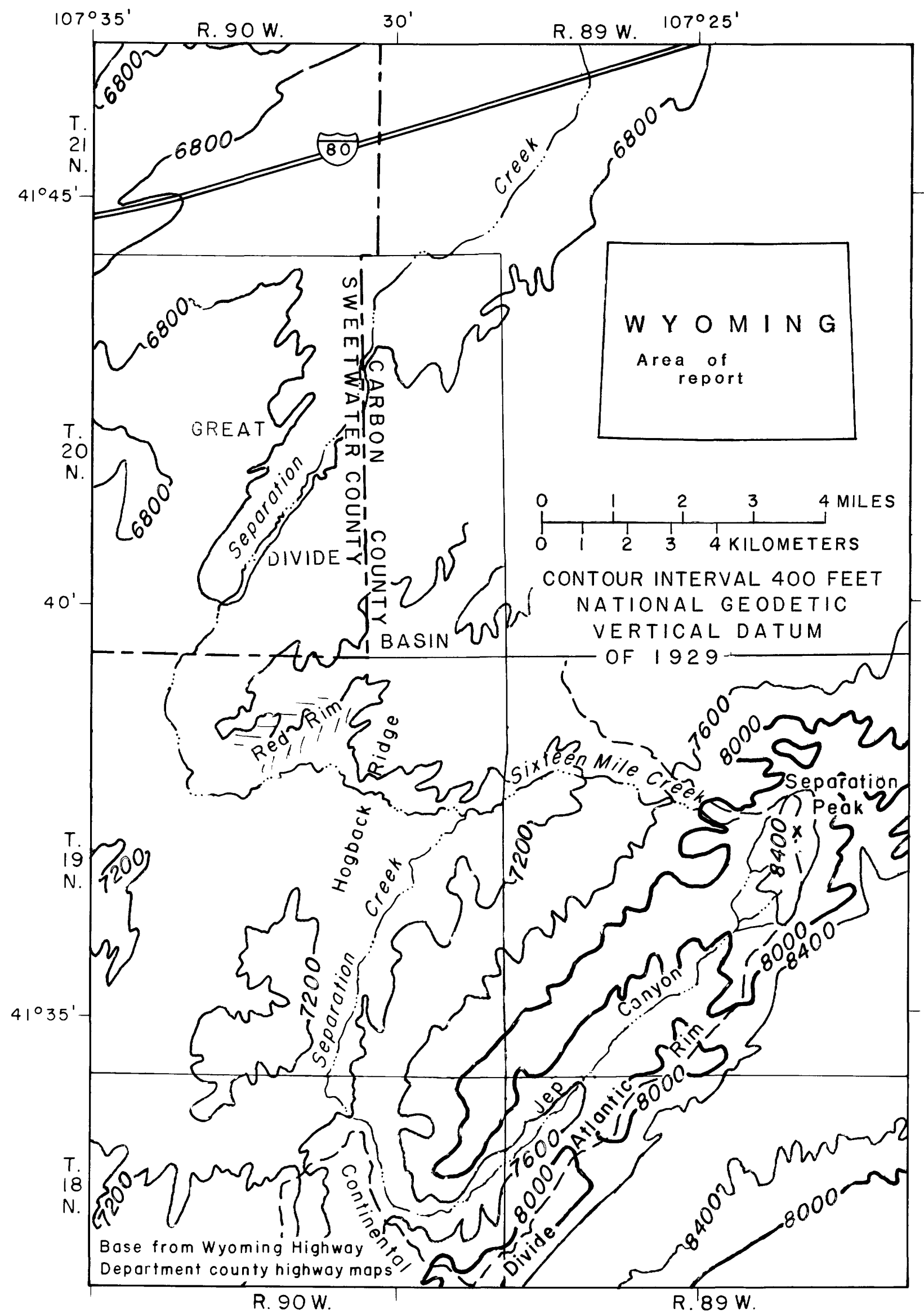

Figure 2.--Separation Creek in south-central Wyoming flows from the head of Jep Canyon and breaches several ridges before crossing Interstate Highway 80 . 


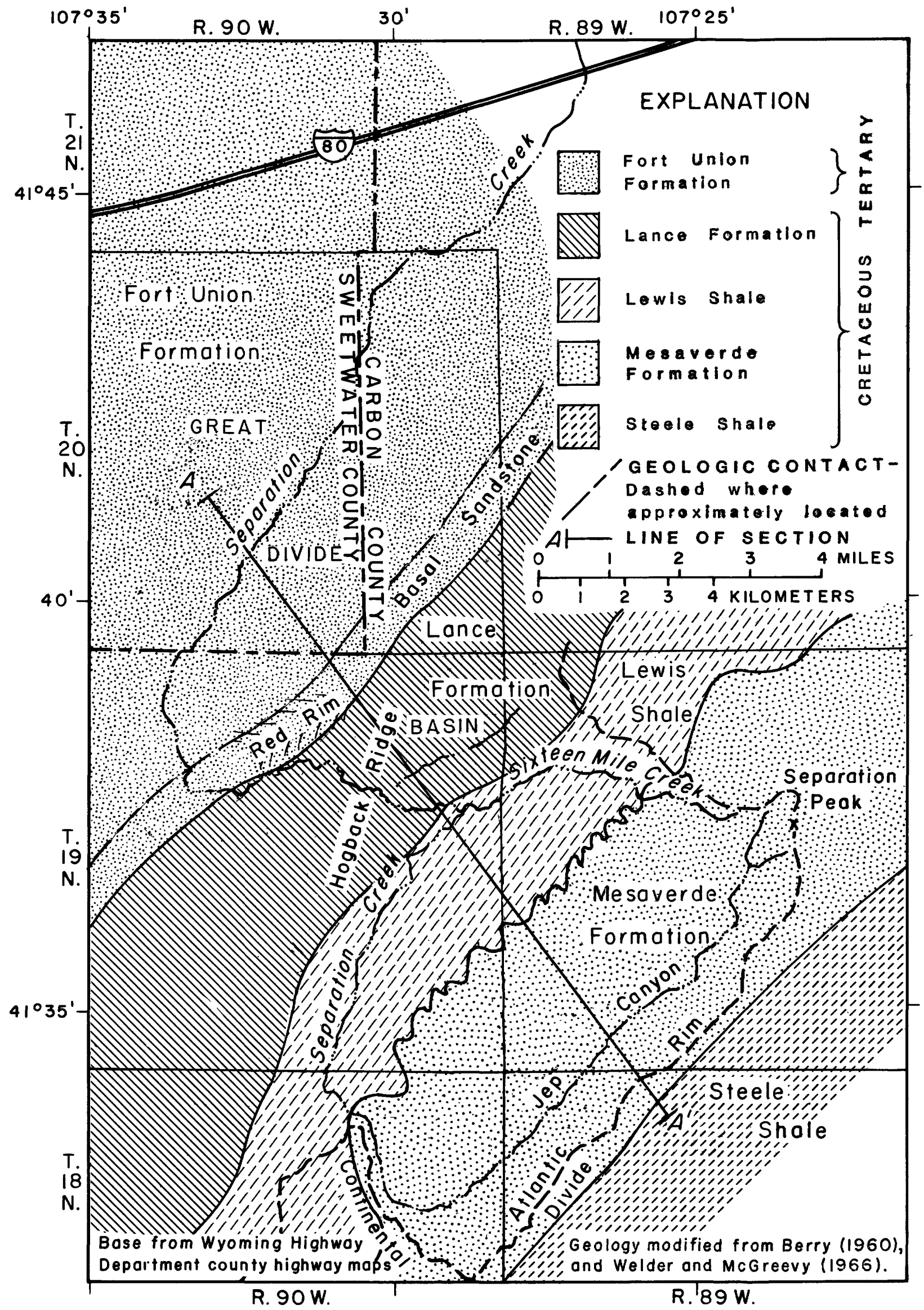

Figure 3.--Sedimentary rocks, from the 8 teele Shale to the Fort Union Formation, underlie the study area. Line $A-A^{\prime}$ is the line or section in figure 4. 


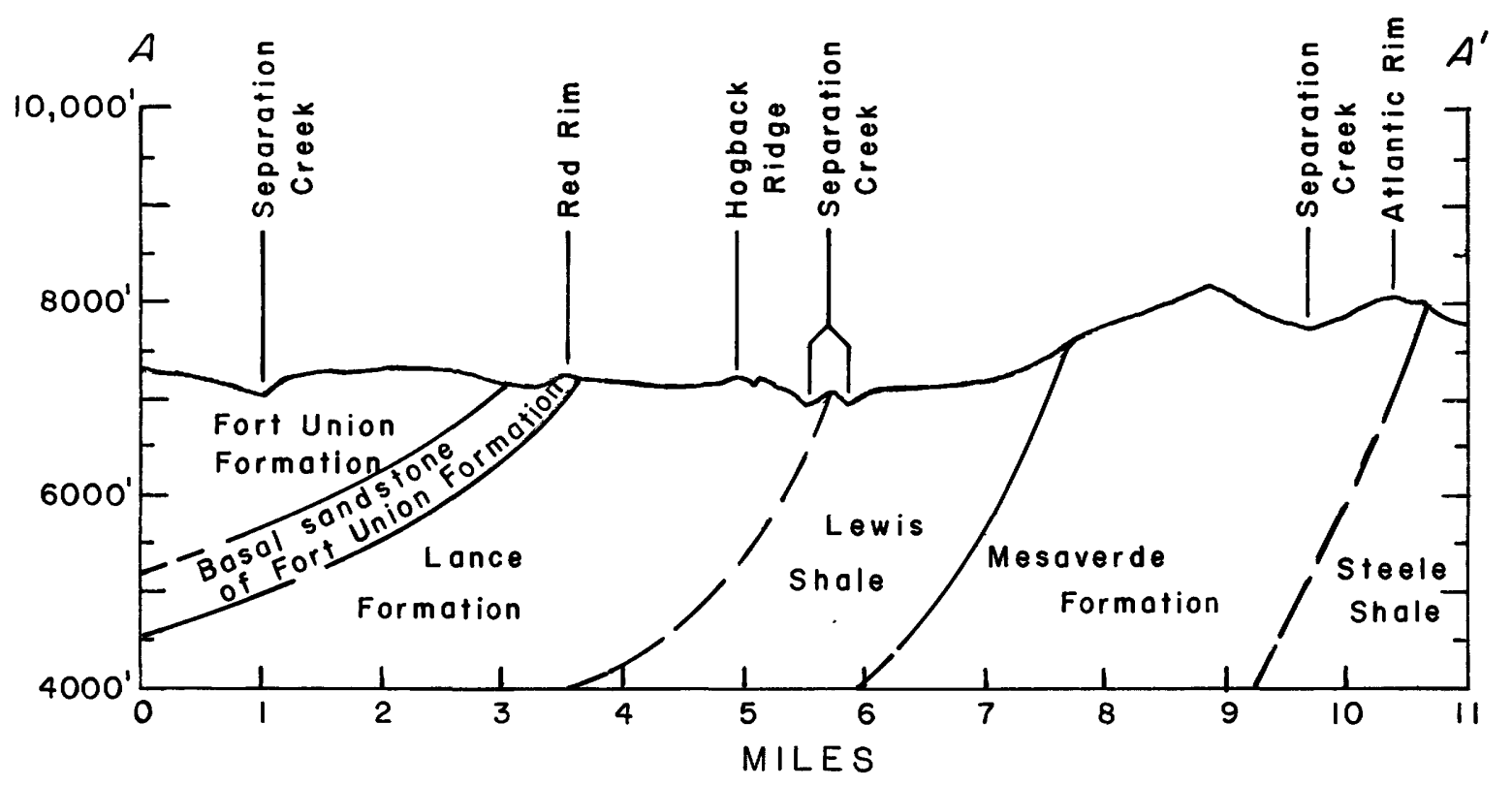

VERTICAL EXAGGERATION X 4

NATIONAL GEODETIC VERTICAL

DATUM OF 1929

Figure 4.--Sedimentary rocks, from the Steele Shale to the Fort Union Formation, dip steeply to the west-northwest across the upper Separation Creek basin. Line of section $A-A^{\prime}$ is shown in figure 3 . 
The Mesaverde Group comprises more than 2,500 feet of sandstone, shale, and coal. Sandstone beds are as much as 120 feet thick and compose more than 50 percent of the formation. These resistant beds dip about 30 degrees west-northwestward and form the Atlantic Rim escarpment. Most of the sandstone is very fine to fine grained (Berry, 1960, p. 61-63).

The Lewis Shale consists of about 2,000 feet of dark-gray fissile shale grading into buff sandy shale (Sanders, 1974). Lenses of gray to buff, sandy, calcareous siltstone and dark-gray to brown, carbonaceous material are interspersed in the formation. Thin bentonite beds and brown sandstone concretions are common. The Lewis Shale underlies the strike valley through which Separation Creek flows from the mouth of Jep Canyon to the mouth of Sixteen Mile Creek. The shale is rarely exposed because the topography is comparatively subdued and is mantled by colluvium or al.luvium derived from the Mesaverde or Lance Formations.

The Lance Formation is composed of a maximum of almost 4,000 feet of interbedded light-gray sandstone and medium- to dark-gray and gray-green shale. The lower half of the formation includes several beds of coal, some of which have been mined in T. 20 N., R. 88 W. (Sanders, 1974). Sandstone beds near the base of the Lance form the prominent Hogback Ridge escarpment. A partly covered geologic section north of the study area, which was measured by $\mathrm{J}$. A. Barlow and included in a report by Berry (1960, p. 60-61), indicates that sandstone constitutes less than 10 percent of the Lance. The Lance dips about 20 degrees toward the northwest.

The Fort Union Formation comprises almost 3,500 feet of sandstone, conglomerate, siltstone, shale, and coal. The beds, generally lenticular, dip northwest from about 20 degrees along the basal edge to less than 10 degrees along the northwest edge of the study area.

The basal sandstone of the Fort Union Formation is 500 to 600 feet thick (Sanders, 1974) and forms the Red Rim, as shown in figure 5. Although the basal sandstone is light gray, it weathers pink, red, or brown. It is a thick-bedded to massive, medium- to coarse-grained, crossbedded sandstone. Chert-pebble conglomerates are interspersed in the bed, and, locally, dark-gray shale separates sandstone layers.

Windblown sand of Holocene age occurs in scattered dunes on the lee (eastern) side of Separation Creek in the northern quarter of the study area. The sand is unconsolidated, well sorted, light brown, fine grained, and generally associated with friable sandstone lenses in the middle part of the Fort Union Formation (Sanders, 1974).

Alluvium and colluvium have been mapped only in the Riner quadrangle in the western part (Tps. 19 and $20 \mathrm{~N}$., Rs. 90 and 91 W.) of the study area (Sanders, 1974). However, colluvium is very widespread throughout the area and consists of weathered bedrock detritus. Alluvium underlies the floodplain of Separation Creek and some of its tributaries. Most of the alluvium is silt or clay, but sand and gravel occupy the deeper parts of the alluvial deposits. Alluvium is as much as 22 feet thick along Separation Creek. 


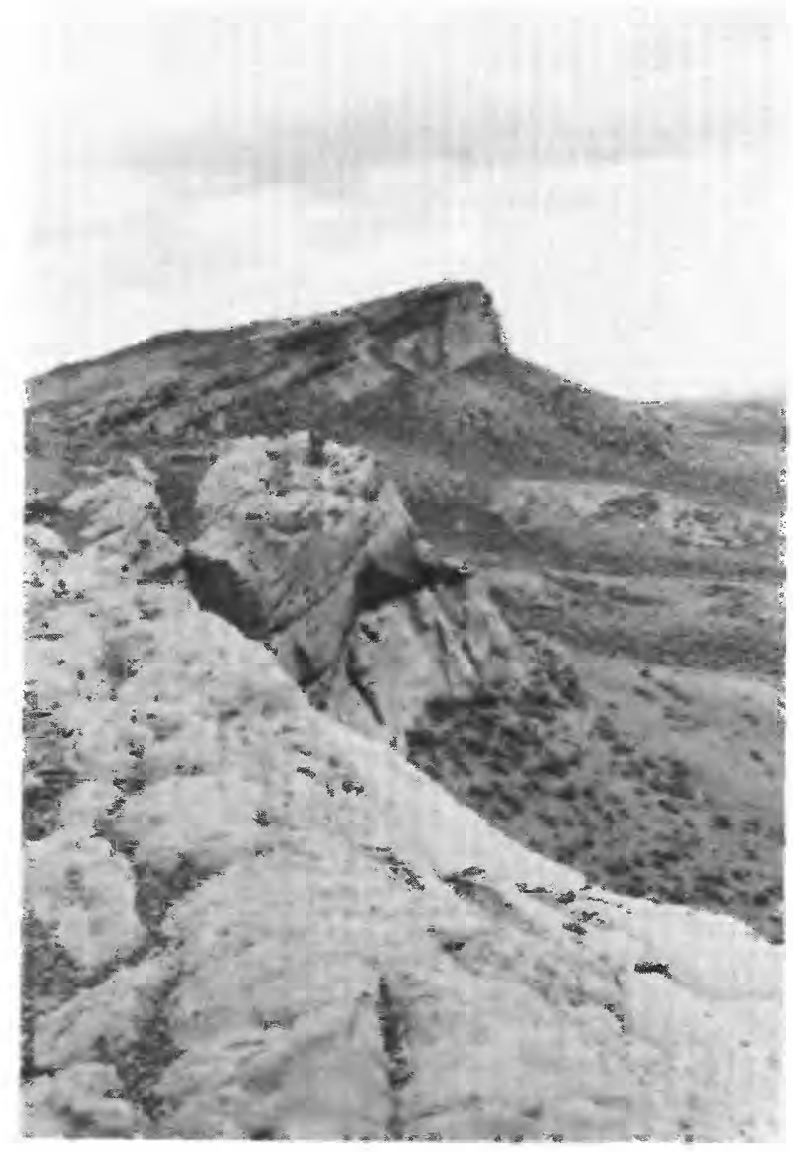

Figure 5.--The basal sandstone of the Fort Union Formation forms the topographically prominent Red Rim. View northeastward from section 3, T. 19 N., R. 90 W. 


\section{Climate}

Rawlins is the location of the nearest National Weather Service station to the study area. The range in temperature at Rawlins is illustrated in figure 6. Although temperatures colder than $-36^{\circ} \mathrm{F}\left(-38^{\circ} \mathrm{C}\right)$ and warmer than $100^{\circ} \mathrm{F}\left(38^{\circ} \mathrm{C}\right)$ have been recorded, mean monthly temperatures range from $21^{\circ} \mathrm{F}$ $\left(-6^{\circ} \mathrm{C}\right)$ to $68^{\circ} \mathrm{F}\left(20^{\circ} \mathrm{C}\right)$. The mean annual temperature is about $43^{\circ} \mathrm{F}\left(6^{\circ} \mathrm{C}\right)$.

Month-to-month variability of the precipitation at Rawlins is shown in figure 7. Annual precipitation averages 10.43 inches per year (1931-60). May is normally the wettest month and November the driest, but precipitation is unpredictable. May has had as little as 0.03 inch and November as much as 1.46 inches of precipitation. The greatest annual precipitation recorded was 17.00 inches in 1912; the least was 3.82 inches in 1907 (U.S. Department of Commerce, 1905-77). The annual precipitation has been between 8 and 12 inches for more than 50 percent of the period of record.

Although Rawlins is the nearest weather station to the study area, vegetation indicates that the climate at Rawlins may typify only the lower parts of the upper Separation Creek basin. The elevation and aspect (northfacing or south-facing slopes, for example) affect the temperatures and precipitation. Precipitation increases and temperature decreases with increased elevation. Effective temperatures and consequent evapotranspiration are greatest on south- and west-facing slopes.

In the Red Rim EMRIA report by the U.S. Bureau of Land Management (1976), potential evapotranspiration was estimated for the growing season (AprilOctober) using the Blaney-Criddle method for grassland (fig. 8). Potential evapotranspiration exceeds average precipitation during all the months of the growing season.

Strong winds periodically sweep the study area throughout the year but are especially prevalent during the winter and spring. Prevailing winds are from the west.

\section{Vegetation}

Although the vegetation of upper Separation Creek basin is broadly classified as northern desert shrub, a large variation in both type and density of vegetal cover exists. The vegetation within Jep Canyon consists of grasses and sagebrush interspersed with stands of aspen, juniper, and pines. Willow thickets are scattered along the stream channel. Generally, no trees are found downstream from the mouth of Jep Canyon aside from an occasional willow thicket. In the downstream reaches of the study basin, vegetation is sparse and consists of low shrubs such as shadscale and saltbrush. The flood plain of Separation Creek, compared to the uplands, generally supports a lush assemblage of plants, including many that depend on shallow ground water. 


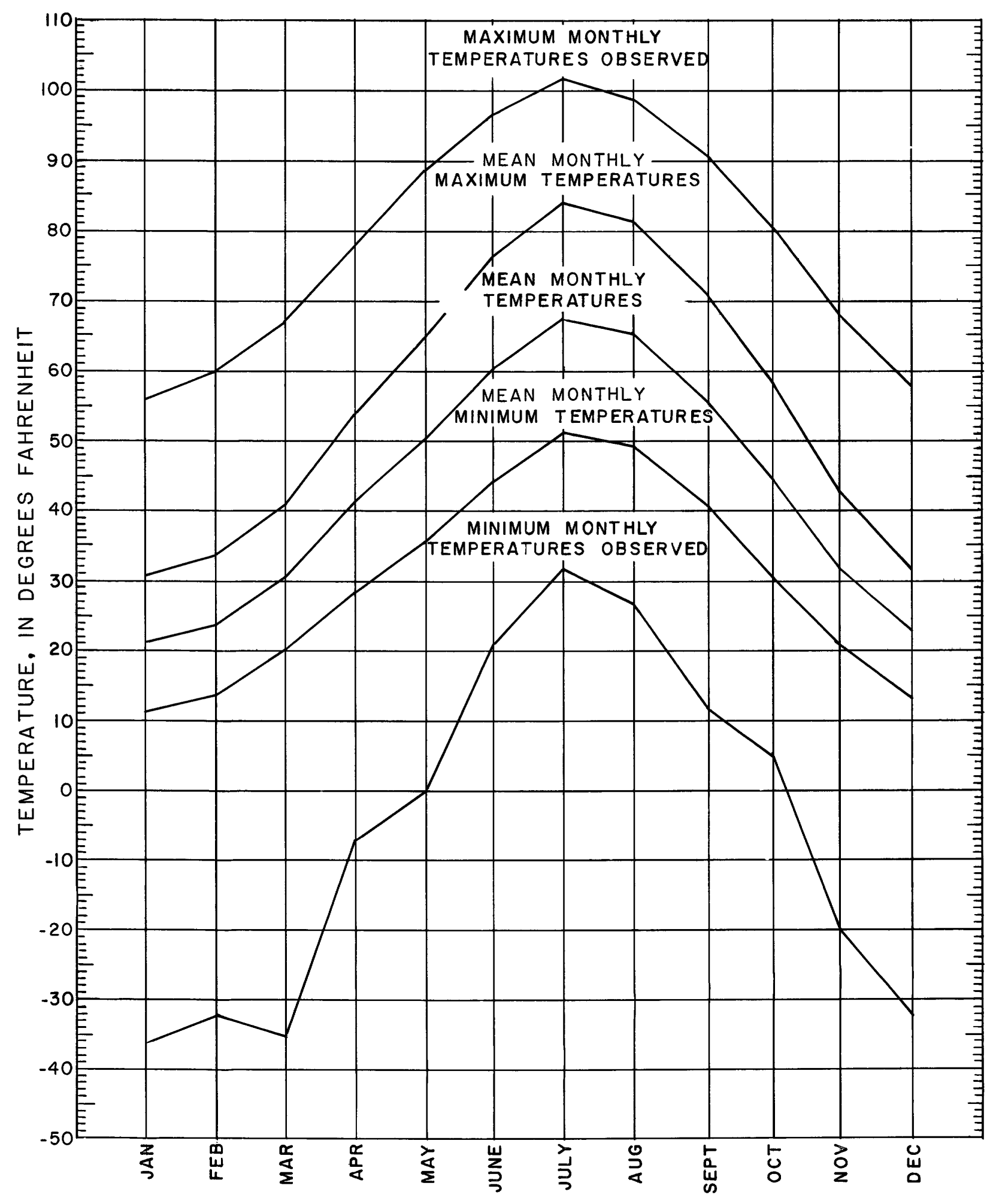

Figure 6.--Extreme temperatures observed at Rawlins, Wyoming, range from $-36^{\circ} \mathrm{F}\left(-38^{\circ} \mathrm{C}\right)$ to more than $100^{\circ} \mathrm{F}\left(38^{\circ} \mathrm{C}\right)$, though mean monthly temperatures range from $21^{\circ} \mathrm{F}\left(-6^{\circ} \mathrm{C}\right)$ to $68^{\circ} \mathrm{F}\left(20^{\circ} \mathrm{C}\right)$. (From Becker and Alyea, $1964 \mathrm{a}, \mathrm{p} .141$. 


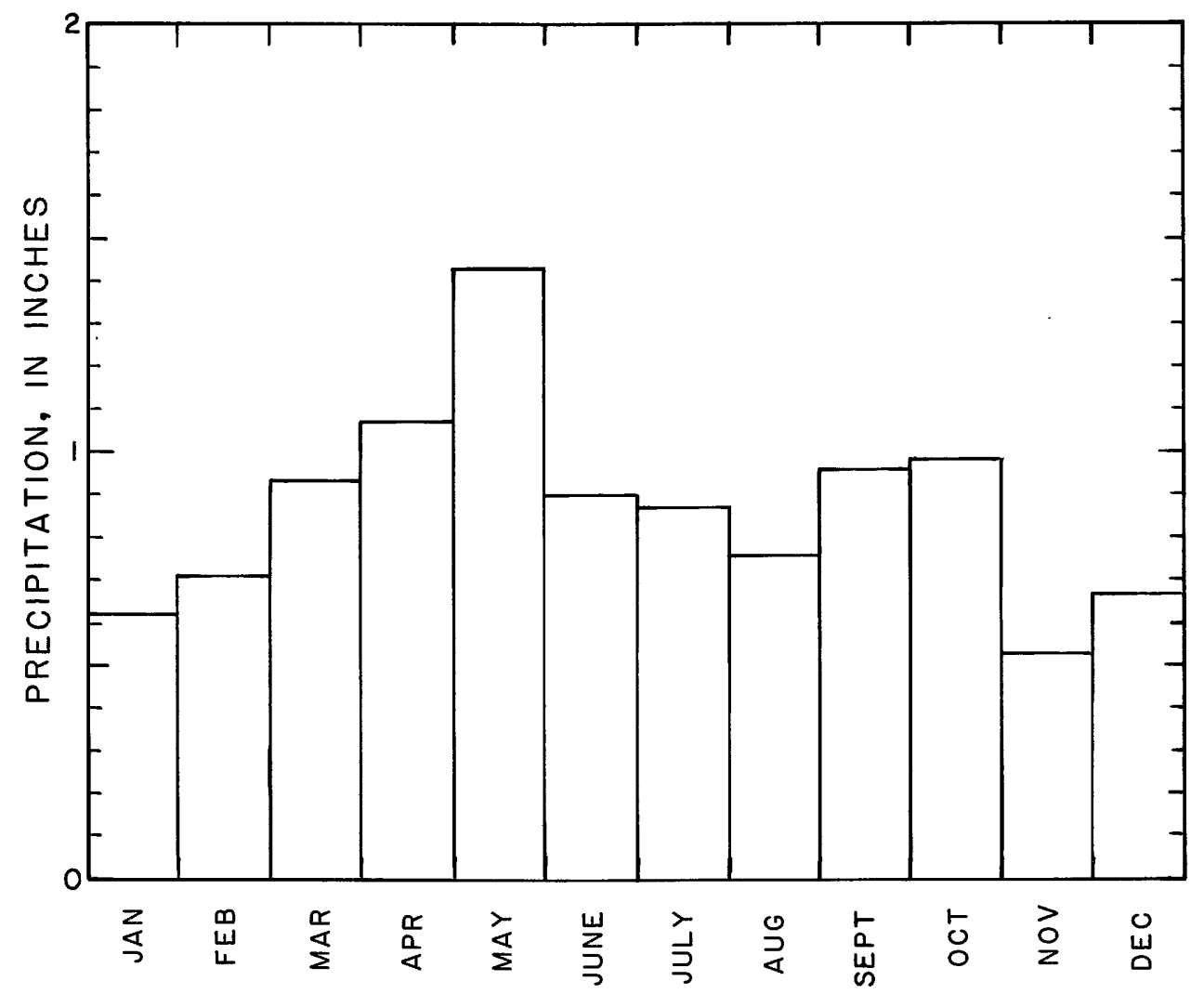

Figure 7.--The average monthly precipitation at Rawlins (1931-60) ranges from about 0.5 inch during November to more than 1.4 inches during May. (From Becker and Alyea, 1964 b, p. 9.) 


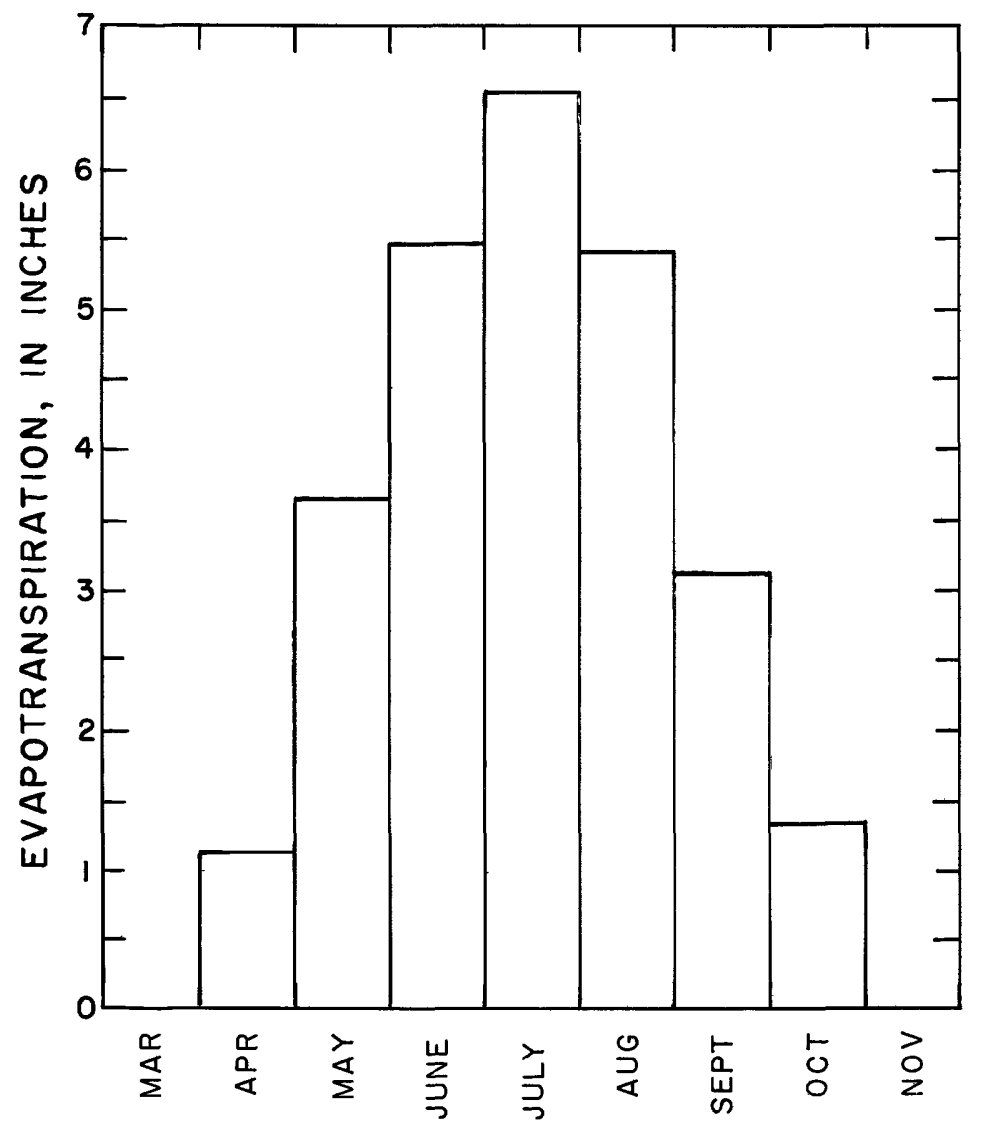

Figure 8.--Potential evapotranspiration during the growing season estimated by the Blaney-Criddle method for grassland is about 6.5 inches during July. (Data from U.S. Bureau of Land Management, 1976.) 
Separation Creek is, for most of its length, an ephemeral stream that flows in response to snowmelt and rainstorms. Springs and rainstorms contribute to streamflow but snowmelt is the biggest contributor.

To record streamflow, a streamflow gaging station (site S-29) (fig. 9) was installed during the fall of 1975. The first intermittent flow during the 1976 water year began with an early thaw on February 8 (fig. 10). Uninterrupted flow began on February 27 and continued into July. This period of flow was due largely to snowmelt, first at lower elevations and finally from the last snow that remained from the considerable snowpack on the upper rims bordering the creek. Photographs taken on March 29, 1976, (fig. 11) contrast the snowpack in Jep Canyon at about 7,800 feet with the much lighter snowpack around site S-29 at approximately 6,800 feet.

During the 1976 spring runoff, streamflow from snowmelt was augmented by ground-water discharge and a few rainstorms. The instantaneous peak flow during the 1976 water year was $39 \mathrm{ft}^{3} / \mathrm{s}$ on April 6, and was due only to snowmelt. The last snowdrifts melted during late June, and flow ceased at the gage shortly thereafter. The spring runoff during the 1977 water year resulted in uninterrrupted flow at the gage from March 25 to May 8.

During 1976, three rainstorms produced runoff at the gage. The first during June augmented the snowmelt runoff. The second during July produced about $1 \mathrm{ft}^{3} / \mathrm{s}$ and the third during August produced less than $0.1 \mathrm{ft}^{3} / \mathrm{s}$. The last two flows each lasted for less than 2 days. During 1977, rainstorms produced runoff during May, July, and August. Peak flows caused by rainstorms tend to be flashy; for example, rainfall caused an instantaneous peak flow of $77 \mathrm{ft}^{3} / \mathrm{s}$ on July 23, 1977, although the mean discharge for the day was only $11 \mathrm{ft}^{3} / \mathrm{s}$. This contrasts with the broader peaks caused by snowmelt. For example, snowmelt caused an instantaneous peak flow of $39 \mathrm{ft}^{3} / \mathrm{s}$ on April 6 , 1976. The mean discharge for that day was $26 \mathrm{ft}^{3} / \mathrm{s}$.

Springs provide some flow, especially in the upstream reaches of the creek; however, without augmentation from snowmelt or rain, ground-water inflow is not sufficient to maintain flow through the entire reach of the study area. The part of the creek in Jep Canyon is a series of beaver ponds. By late summer 1976, the upstream reach of the creek and some of the reaches between the beaver ponds were dry.

An average annual runoff of 2,500 acre-feet for Separation Creek at site S-29 was estimated from the following information: (1) Runoff at the gage for the 1976 water year (Oct. 1, 1975-Sept. 30, 1976) was 2,040 acre-feet; and (2) the two ranchers (Sun and Hanson, oral commun., 1976) familiar with the creek believed that the 1976 runoff was slightly less than normal. An annual discharge of 2,500 acre-feet is equivalent to 0.85 inch of runoff for the 55 square miles of drainage area upstream from the gage. Parts of the Great Divide Basin just north of the study area have runoff as small as 0.1 inch per year, and the Sierra Madres, not far to the south, produce runoff of 20 inches per year or more (Busby, 1966). A smaller variation in runoff than the above would likely be found in upper Separation Creek basin between the higher elevations in the southern part of the basin and the lower elevations in the northern part. 


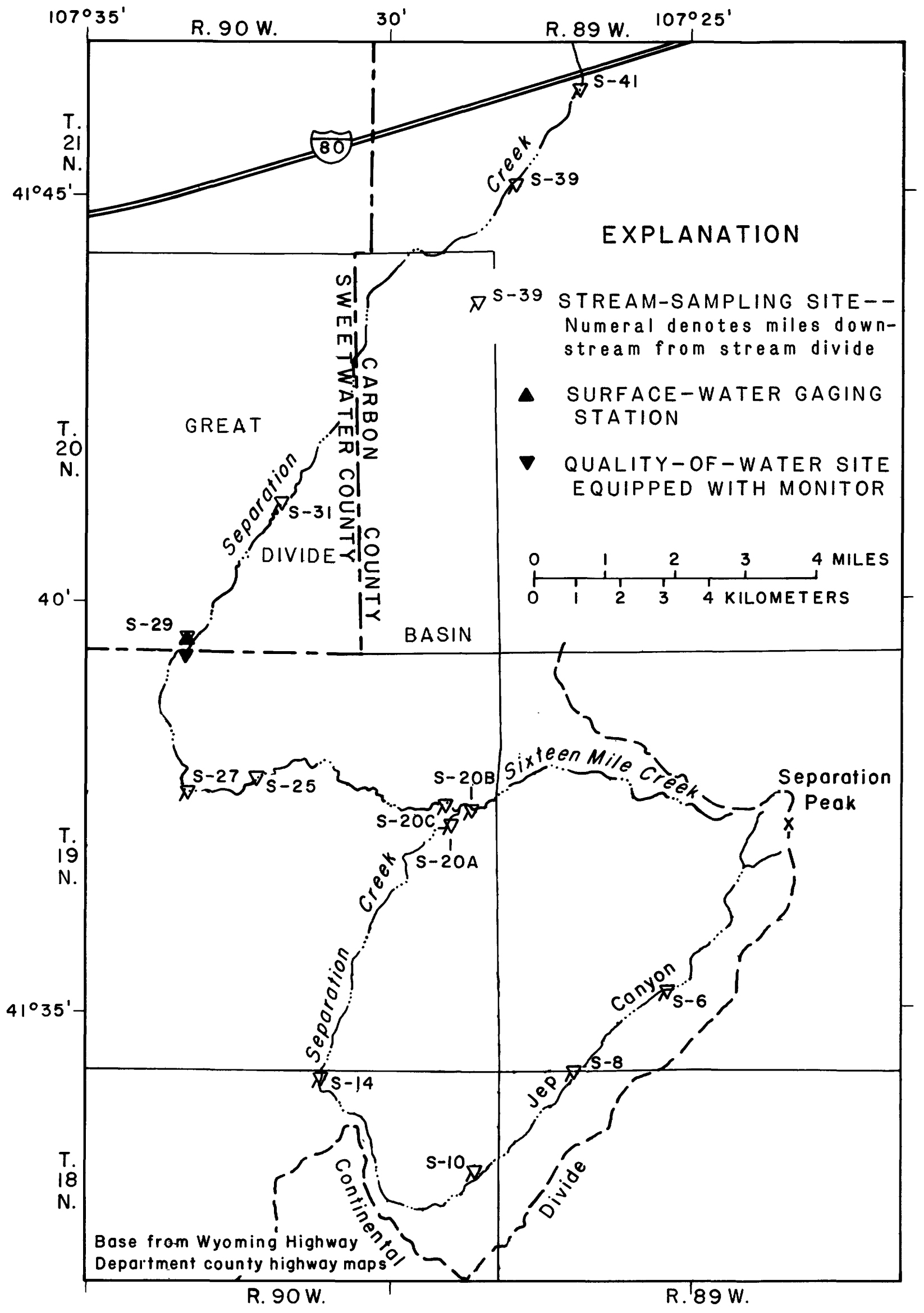

Figure 9.--Location of stream sampling site's in upper Separation Creek drainage. 


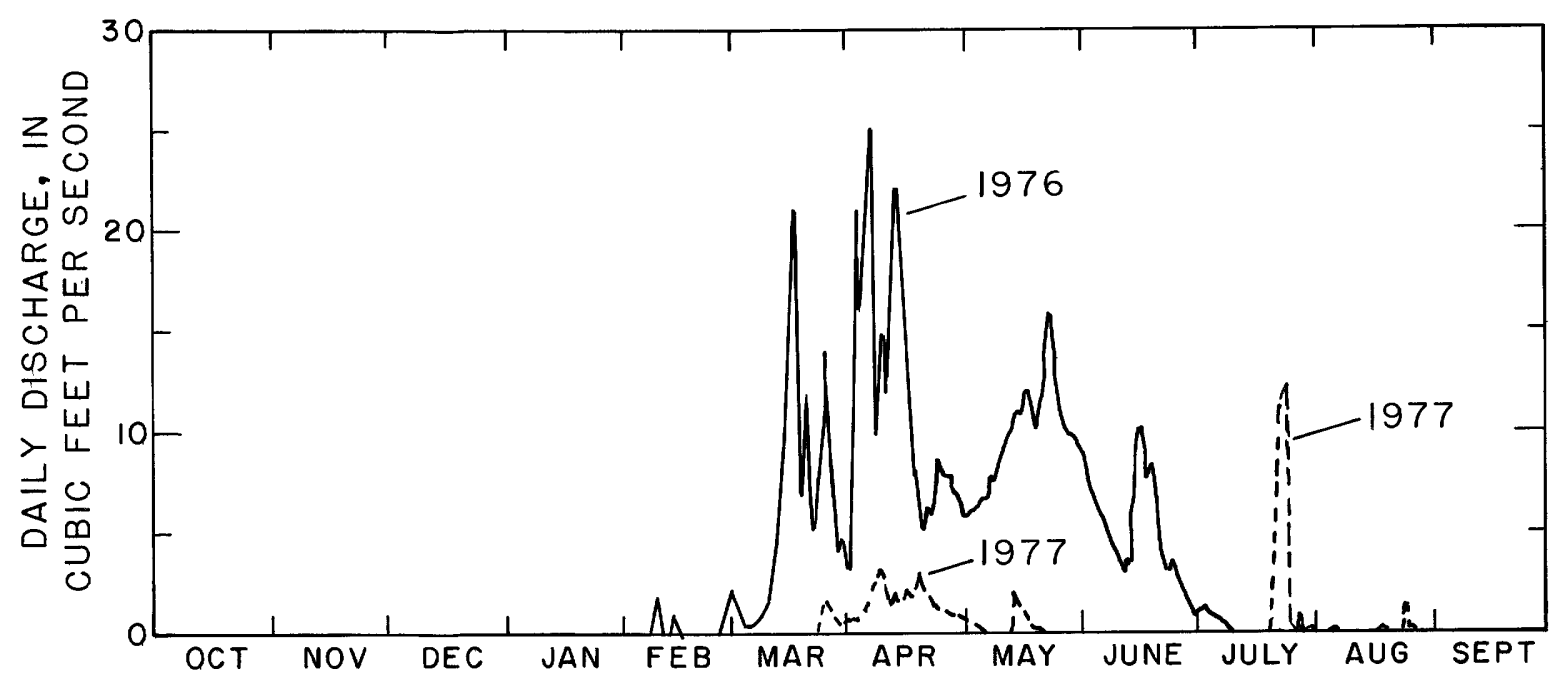

Figure 10.--Hydrographs of upper Separation Creek for 1976 and 1977 water years at site $S-29$ show a greatly reduced runoff during 1977. 

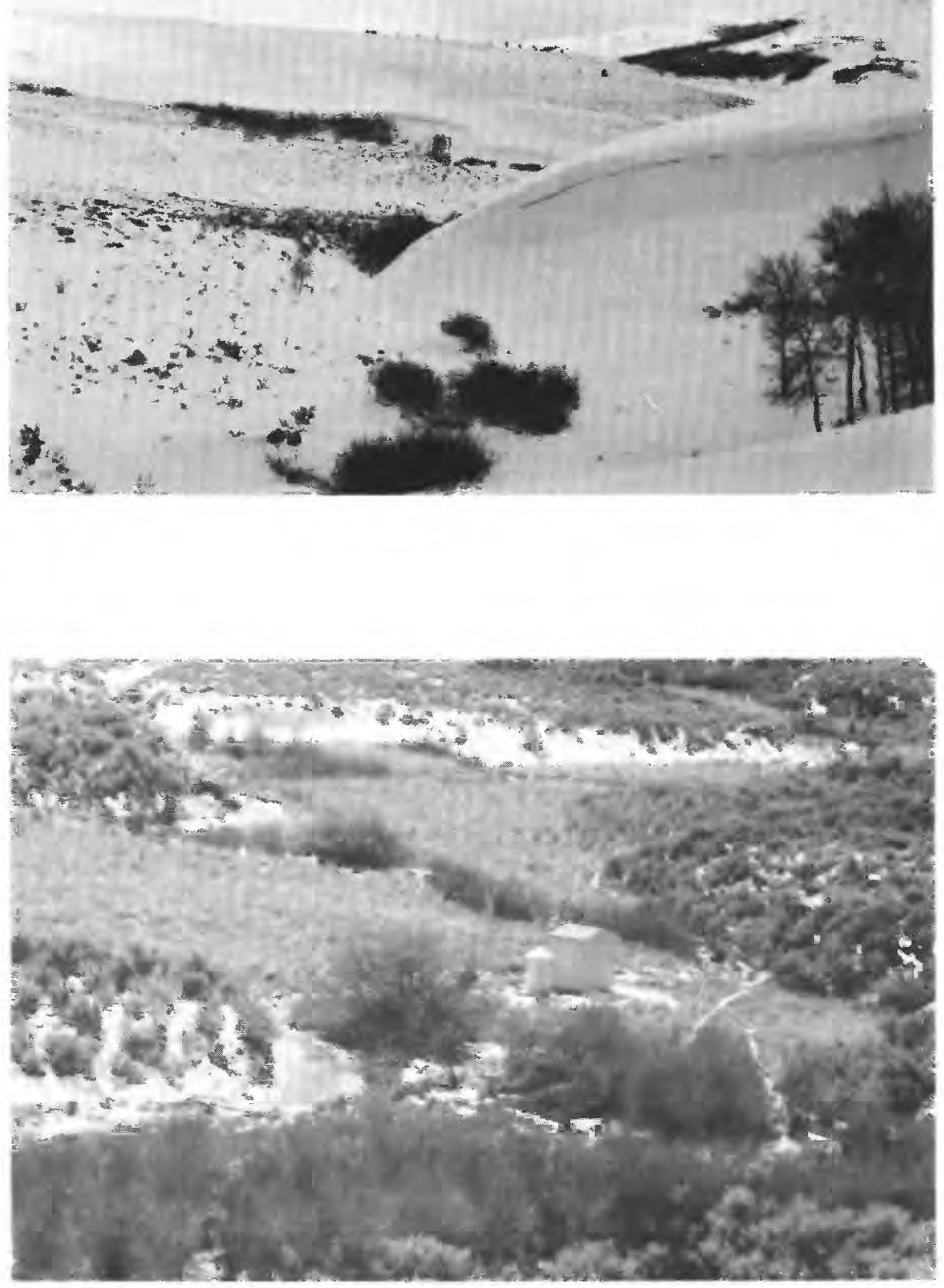

Figure 11.--Photographs taken March 29, 1976 , show the contrast between the heavy snowpack in Jep Canyon at 7,800 feet (upper photograph) and the snowpack around site $S-29$ at 6,800 feet (lower photograph). 
Estimates of peak flows at the gage (site S-29) determined by a channel-geometry method (Lowham, 1976) for the following recurrence intervals are:

$$
\begin{aligned}
2 \text {-year peak flow }=39 \mathrm{ft}^{3} / \mathrm{s}, \\
5 \text {-year peak flow }=100 \mathrm{ft}^{3} / \mathrm{s}, \\
10 \text {-year peak flow }=170 \mathrm{ft}^{3} / \mathrm{s}, \\
25 \text {-year peak flow }=290 \mathrm{ft}^{3} / \mathrm{s}, \\
50 \text {-year peak flow }=420 \mathrm{ft}^{3} / \mathrm{s} .
\end{aligned}
$$

The drought during the winter of 1976-77, the driest on record, resulted in striking changes in the streamflow of Separation Creek. The volume, period, and distance of flow all were reduced greatly. The spring runoff during the 1976 water year, a below-normal year, was 2,000 acre-feet in contrast to 120 acre-feet during the 1977 water year. During the 1976 water year, snowmelt runoff at the gage started on February 27 and lasted until July 11 for a total of 136 days. During the 1977 water year, flow at the gage began on March 25 and lasted until May 8 for a total of 45 days. During the 1976 spring runoff, Separation Creek flowed out of the study area beyond site S-41 at Interstate Highway 80 . During 1977 , as a result of the much smaller spring runoff, flow in Separation Creek terminated upstream from Interstate Highway 80 due to channel losses. The contrast in runoff for these 2 years is shown in figure 10 .

A synoptic comparison of streamflow during May 1976 to that during May 1977 (fig. 12) shows the greatly reduced streamflow during May 1977. This reduction was due to the winter drought of 1976-77. The May 1977 streamflow was so drastically reduced from that of the previous May that surface flow ended at mile 26 between sites S-25 and S-27 (fig. 9). Ground-water inflow downstream from mile 26 was sufficient only to maintain pools and short reaches of flow in the stream.

In Jep Canyon, farther upstream, reduced streamflow resulted in a dry beaver pond in the channel upstream from site S-6 as shown in figure 13 . Normally, the section of the stream shown would be flowing during May from snowmelt and spring inflow (based on observation during 1976 and conversations with local ranchers). The dry beaver pond is additional evidence of the severity of the drought.

\section{GROUND-WATER AVAILABILITY}

Ground water is the most reliable source of water in the upper Separation Creek basin. Ranchers have drilled about 10 wells in the northern part of the basin to provide livestock water. A similar number of springs in the southern part of the basin provide water for livestock, game, and beaver ponds. Some stream reaches are sustained for much of the year by spring flow, and much of the lusher vegetation depends on its ability to use ground water.

The locations of selected wells and springs in the Separation Creek study area are shown in figure 14. A listing of the wells and springs is presented in table 1. Many of the wells and springs in the table and some mentioned in the text are not shown in figure 14. These are included because they supplement wells and springs within the study area in representing ground-water conditions. 


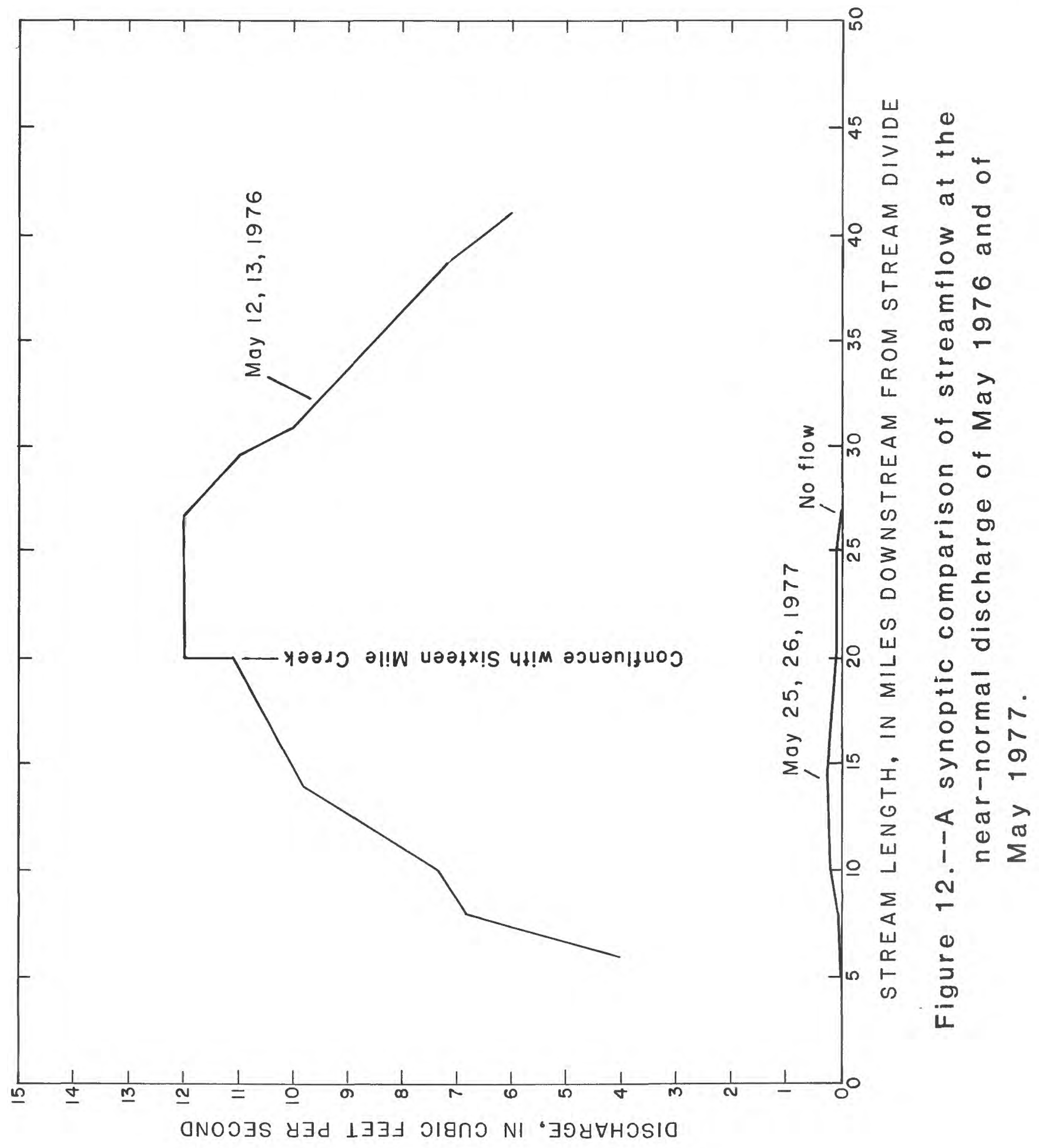




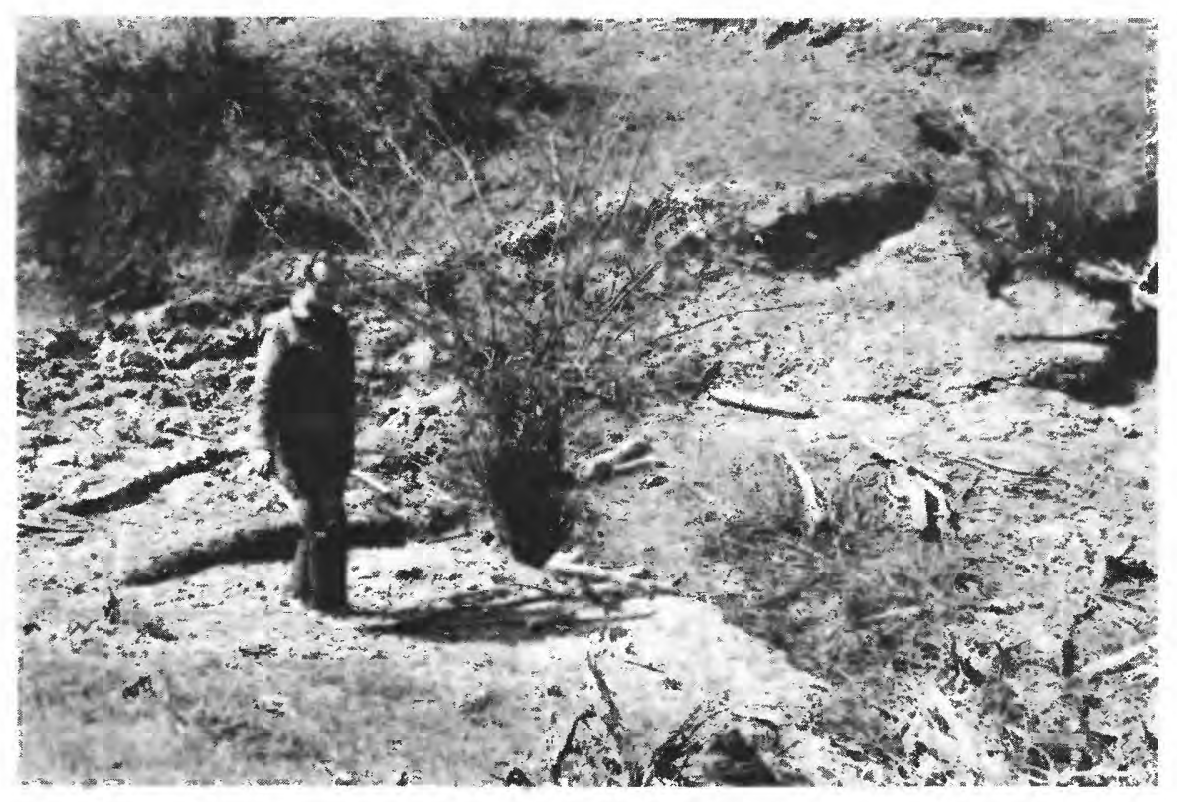

Figure 13.--A dry beaver pond in the stream channel during May 1977 illustrates the lack of snowpack runoff in Jep Canyon upstream from site $S-6$. 


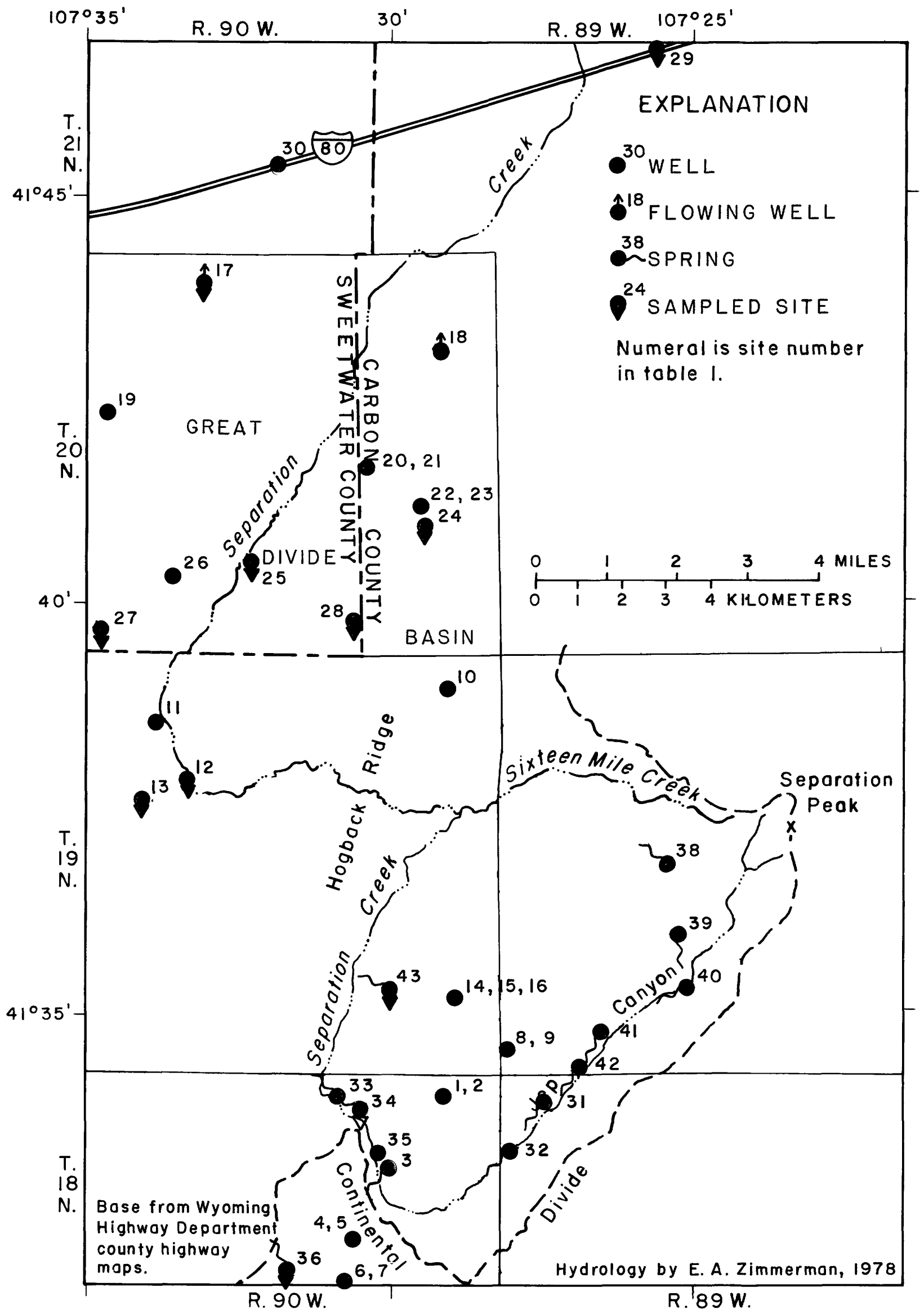

Figure 14.--The locations of selected ground-water sites in the study area are shown on this map. 


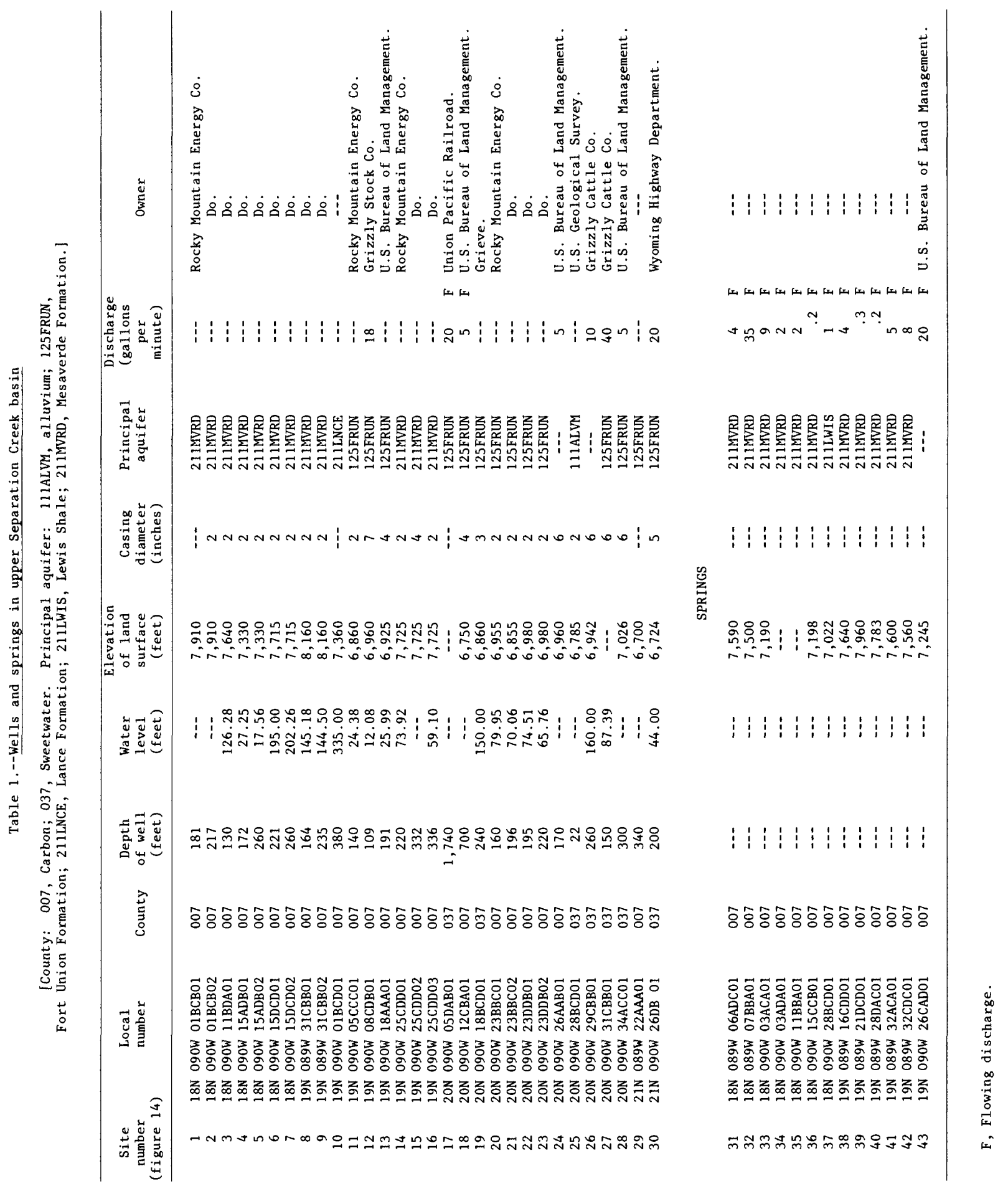


The Mesaverde Formation is a source of many springs along the Atlantic Rim. Some springs yield as much as $35 \mathrm{gal} / \mathrm{min}$, but many are mere seeps. No production-water wells penetrate the Mesaverde in the study area, but the Rocky Mountain Energy Co. has installed 16 small-diameter (2-inch) test wells, or piezometers, in the Mesaverde along Atlantic Rim to permit monitoring of the hydrologic effects of mining. Eight of the wells are in the study area and, of these, six are adjacent, paired wells screened at different depths (usually in coal beds).

The elevations of observed water levels in 4 Rocky Mountain Energy Co. test wells open to the Mesaverde Formation and the elevations of 15 springs are shown in figure 15 .

Because of the steep dip (about $30^{\circ}$ ) and the fact that the various springs and wells do not obtain water from the same beds, the water-level elevations do not indicate a single potentiometric surface. The map is included to show measured water-level elevations prior to mining and not to make quantitative implications about the hydrology of the Mesaverde Formation. The map can be used to estimate the depths to which mining can be done before dewatering will be necessary, but final mining plans need to be based on more specific information.

R. W. Davis (written commun., 1976) conducted six aquifer tests using wells open to various coal beds in the Mesaverde Formation. Five tests were so-called "slug" tests in which a known volume of water was instantaneously injected into or withdrawn from a well. The decline or recovery of the water level was then measured. A pumping test and slug test were conducted on one of the five wells. Davis obtained transmissivity values (a measure of an aquifer's ability to transmit water) of 19 ( $\left.\mathrm{ft}^{3} / \mathrm{d}\right) / \mathrm{ft}$ using data from the pumping test and $15\left(\mathrm{ft}^{3} / \mathrm{d}\right) / \mathrm{ft}$ using data from the slug test. Transmissivity is expressed in the expanded form (cubic foot per day per foot) or in the reduced form (foot squared per day). Transmissivities estimated from the five slug tests ranged from 0.7 to $15\left(\mathrm{ft}^{3} / \mathrm{d}\right) / \mathrm{ft}$ except for a well near a suspected fault zone which had an estimated transmissivity of $20\left(\mathrm{ft}^{3} / \mathrm{d}\right) / \mathrm{ft}$. This last test probably is more indicative of the water-yielding capacity of a thicker section of the Mesaverde, as opposed to the other tests which tested only 10 to 15 feet of coal beds.

Water levels show that, except on the highest parts of Atlantic Rim, the potentiometric surface is higher in deeper beds. Differences as great as 20 feet were measured in wells less than 6 feet apart where the difference in depths was less than 100 feet. Flowing wells can probably be obtained by drilling through several hundred feet of the Mesaverde Formation. Natural discharge probably occurs by upward leakage and from springs. Springs issuing from the Lewis Shale in sec. 3, T. $18 \mathrm{~N} .$, R. $90 \mathrm{~W}$. and sec. 26, T. $19 \mathrm{~N}$., R. $90 \mathrm{~W}$. may result from upward movement of water from the Mesaverde, probably along faults, as the Lewis Shale is not an aquifer in the area.

The sandstone beds in the Lance Formation yield water to five wells along the outcrop of the formation. Little is known of the hydrology except that well yields and water quality suffice for livestock use. 


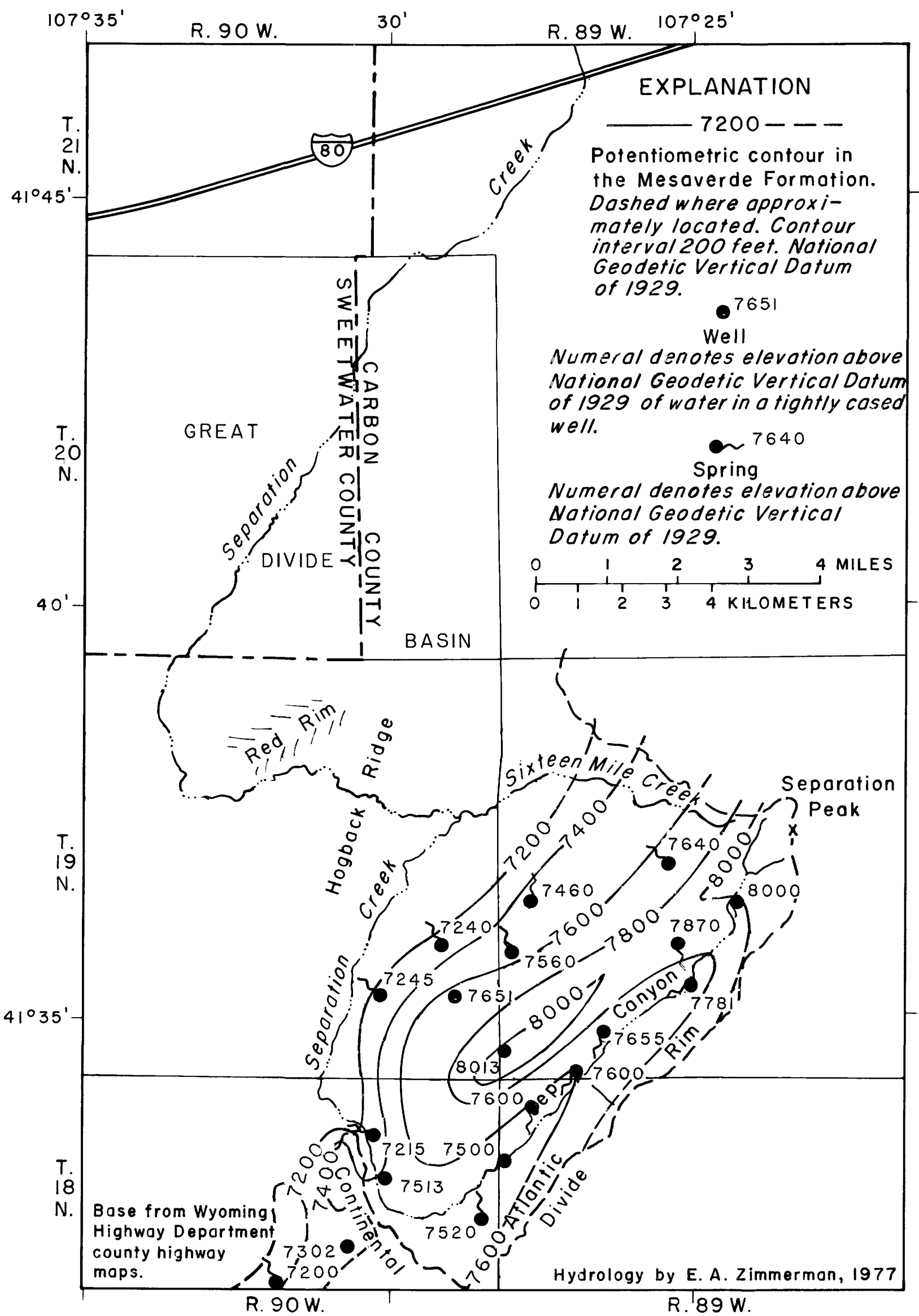

Figure 15.--Well and spring locations and approximate potentiometric surface of water in the Mesaverde Formation in the spring of 1977 . 
The Fort Union Formation underlies the northern part of the study area and contains much of the coal expected to be mined. Yields of wells penetrating the Fort Union in the general study area range from less than 1 to $325 \mathrm{gal} / \mathrm{min}$. The largest yield is in a well 7 miles west of the study area. Yields of wells should be sufficient for camps, dust suppression, or coal washing. Water in the formation may hinder mining by creating a need to dewater excavations.

The Fort Union aquifer provides water for livestock from seven wells in the study area. In addition, Rocky Mountain Energy Co. has installed seven test wells; six of which are paired and open to two aquifers. The U.S. Bureau of Reclamation drilled 10 test holes to explore the coal reserves in 1975. One test hole (19N 090W 18AAA01) was cased and screened for use as an observation well.

Measured water-level elevations in the Fort Union Formation are shown in figure 16. Each lenticular bed, except for the basal sandstone, is so discontinuous that it is doubtful that any two wells are completed in the same beds. The measured water levels indicate that Red Rim is a recharge site and that ground water may flow from it toward Separation Creek or farther into the Great Divide Basin to discharge by interformational leakage. No specific discharge sites are known. Some water is consumed by evapotranspiration on "greasewood flats" along Separation Creek, and some water is discharged and evaporated on broad "alkali flats" out in the basin.

The transmissivity of the coal beds, determined by R. W. Davis (written commun., 1976) from aquifer tests, ranged from 0.5 to 52 ( $\left.\mathrm{ft}^{3} / \mathrm{d}\right) / \mathrm{ft}$. Data from a slug test on one of the U.S. Bureau of Reclamation's test holes indicated a transmissivity of about $44\left(\mathrm{ft}^{3} / \mathrm{d}\right) / \mathrm{ft}$.

The well that produced the maximum yield of $325 \mathrm{gal} / \mathrm{min}$ penetrated almost the entire thickness of the Fort Union Formation. The well was screened or open for 1,100 feet above its total depth of 3,755 feet. Much of the producing section was probably in the basal sandstone of the Fort Union. An aquifer test made by a consulting firm indicated a transmissivity of about $820\left(\mathrm{ft}^{3} / \mathrm{d}\right) / \mathrm{ft}$ (E. P. Fisk, C. E. Jacob and Associates, written commun., 1965).

Alluvium along Separation Creek is in hydraulic connection with the stream. Water goes into bank storage during a rising stage. As the stage declines, some of the water that recharged the alluvium returns to the channel to sustain the flow for a time. As the stage declines further, only a few pools may remain; underflow in the alluvium carries the water from pool to pool and replenishes water lost by evaporation from the pools. The underflow is subject to losses through transpiration by vegetation, and these losses may in turn contribute to stream depletion. When transpiration ceases after the first hard frost in the fall, discontinuous reaches of the creek begin to flow as the water level rises in the alluvium. 


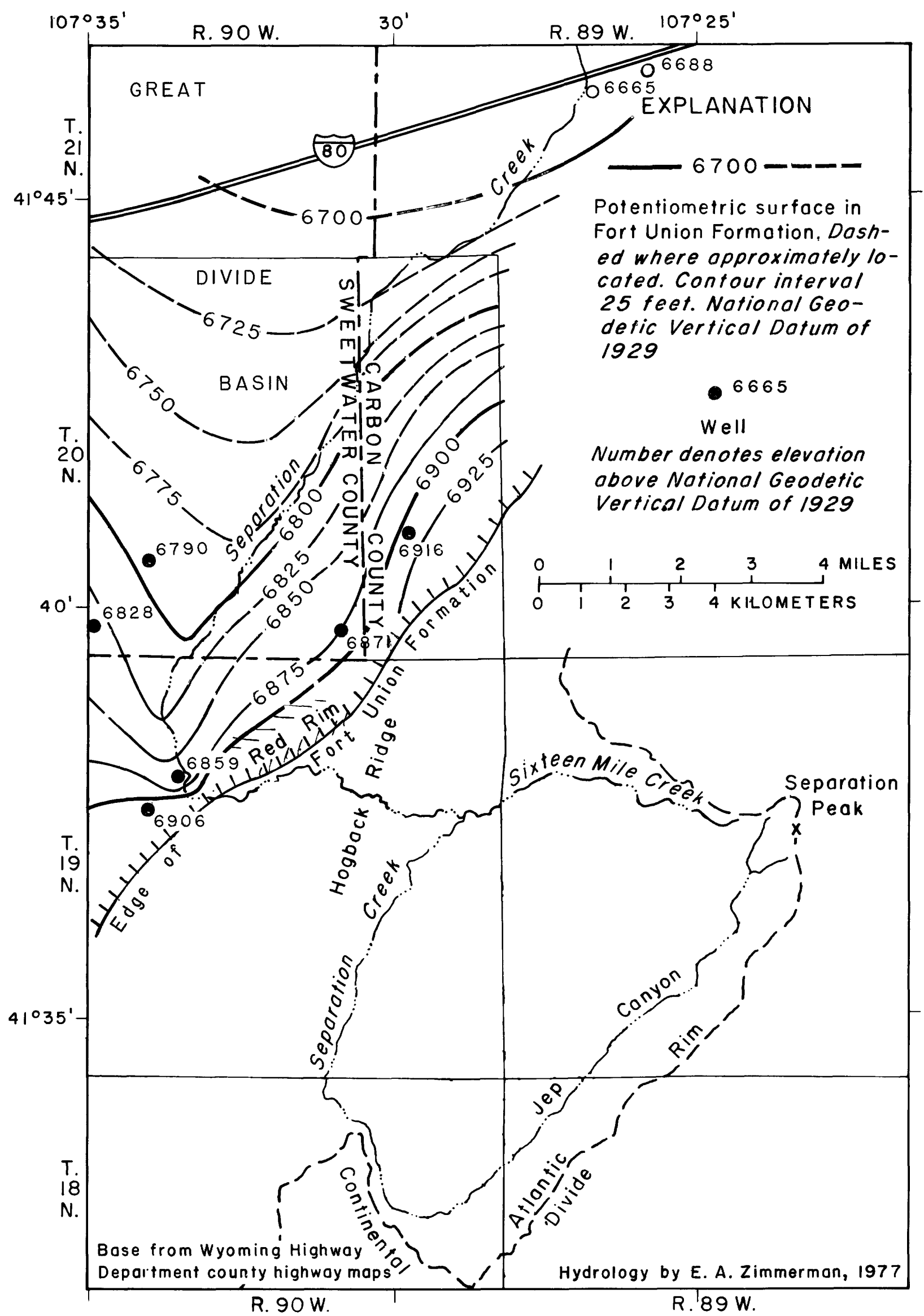

Figure 16.--Well locations and approximate potentiometric surface of water in the Fort Union Formation in the spring of 1977 . 
The reaches of the creek that flow longest or resume flow soonest can be determined in part by the geometry of the alluvial channel as well as by the character of the alluvium. Where the valley is broad and the cross-sectional area is comparatively large, water can be easily transmitted through the alluvium, and the creek may be dry except during relatively high runoff. Where the valley narrows, as where it cuts through resistant beds like the basal sandstone of the Fort Union Formation, flow (or at least pools) may persist for months after most of the stream is dry. According to a local rancher (Steve Sun, oral commun., 1976 ) water persists through much of the year in sec. 8, T. 19 N., R. 90 W., downstream from where Separation Creek breaches the basal sandstone of the Fort Union in a narrow valley, although the creek is dry upstream and downstream from the site most of the year. Conversely, where the valley broadens downstream from sec. 15, T. $20 \mathrm{~N} .$, R. $90 \mathrm{~W}$., the streamside vegetation virtually disappears except for the deep-rooted, salt-tolerant greasewood (Sarcobatus vermiculatus). The stream channel is principally a conduit for snowmelt and rainfall runoff.

\section{WATER QUALITY}

In order to evaluate water quality, it is best to do so with a particular use in mind. For this reason, a brief discussion or graph is presented for each of the following uses: (1) Livestock and poultry watering, (2) irrigation, and (3) domestic-water supply.

Stock and wildlife watering is the principal use of water in the basin. In the absence of toxic concentrations of trace elements, the most important criteria for evaluating water for this use is salinity; that is, the dissolved-solids concentration. Various ranges of dissolved-solids concentrations for livestock and poultry watering are qualified in table 2 .

Dissolved solids and sodium are the constituents most likely to cause problems in the use of water for irrigation. Dissolved solids may be a problem because plants obtain water by osmotic pressure which is proportional to the difference between the dissolved-solids concentration in the plant cells and the dissolved-solids concentration in the soil moisture. Saline irrigation waters tend to increase the soil-moisture salinity thus decreasing the osmotic pressure.

Irrigation waters with a large percentage of exchangeable sodium ions can destroy the soil structure. When calcium and magnesium are the principal ions adsorbed in the soil during ion exchange, the soil tends to be easily worked and permeable. Irrigation waters with large exchangeable-sodium percentages replace the adsorbed calcium and magnesium with sodium. The soil then becomes sticky when wet, bakes hard as it dries, and loses its permeability. The tendency of sodium to replace calcium or magnesium adsorbed on the soil particles is measured by a value called the SAR (sodium-adsorption ratio):

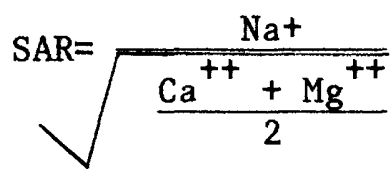

where the ion concentrations are expressed in milliequivalents per liter. 
Table 2.--Guide to the use of saline waters for livestock and poultry

[National Academy of Science and National Academy of Engineering, 1972]

Dissolved-solids

concentration of waters

Comment

(milligrams per liter)

Less than $1,000 \ldots \ldots$ Relatively low level of salinity. Excellent for al1 classes of livestock and poultry.

$1,000-2,999 \ldots \ldots \ldots . .$. Very satisfactory for all classes of livestock and poultry. May cause temporary and mild diarrhea in livestock not accustomed to them or watery droppings in poultry.

3,000-4,999........... Satisfactory for livestock, but may cause temporary diarrhea or be refused at first by animals not accustomed to them. Poor water for poultry, often causing water feces, increased mortality, and decreased growth, especially in turkeys.

$5,000-6,999 \ldots \ldots \ldots \ldots$. Can be used with reasonable safety for dairy and beef cattle, sheep, swine, and horses. Avoid use for pregnant or lactating animals. Not acceptable for poultry.

$7,000-10,000 \ldots \ldots \ldots$. Unfit for poultry and probably for swine. Considerable risk in using for pregnant or lactating cows, horses, or sheep, or for the young of these species. In general use should be avoided although older ruminants, horses, poultry, and swine may subsist on them under certain conditions.

More than $10,000-\cdots---R i s k s$ with these highly saline waters are so great that they cannot be recommended for use under any conditions. 
Drinking-water quality may be evaluated by two Federal standards. The first standard, the National Interim Primary Drinking Water Regulations (U.S. Environmental Protection Agency, 1975), published maximum concentration levels for toxic contaminants. These primary regulations became effective June 24,1977 , and are applicable to all public water supplies. The regulations are enforceable by the States, if they have accepted primacy; if not, they are enforced by the U.S. Environmental Protection Agency.

The second Federal standard, the National Secondary Drinking Water Regulations (U.S. Environmental Protection Agency, 1977), deals with contaminants which affect the asthetic quality (taste, odor, or appearance) as well as the economic and health effects of drinking water. The secondary regulations are not Federally enforceable, but are intended as guidelines for State regulatory agencies.

The National Interim Primary Drinking Water Regulations list maximum inorganic contaminant concentrations as follows:

Contaminant
Arsenic
Barium
Cadmium
Chromium
Fluoride
Lead
Mercury
Nitrate (as nitrogen)
Selenium
Silver

\section{Concentration}

$50 \mu \mathrm{g} / \mathrm{L}$

$1,000 \mu \mathrm{g} / \mathrm{L}$

$10 \mu \mathrm{g} / \mathrm{L}$

$50 \mu \mathrm{g} / \mathrm{L}$

$1.4-2.4 \mathrm{mg} / \mathrm{L}$

$50 \mu \mathrm{g} / \mathrm{L}$

$2 \mu g / L$

$10 \mathrm{mg} / \mathrm{L}$

$10 \mu \mathrm{g} / \mathrm{L}$

$50 \mu \mathrm{g} / \mathrm{L}$

The maximum contaminant concentrations are based on an assumed drinking-water intake of 2 liters per day except for fluoride. The fluoride standard assumes an increase in consumption of water as the annual average of the maximum daily air temperature increases. The maximum concentration for fluoride in drinking water in the study area is $2.2 \mathrm{mg} / \mathrm{L}$, based on an annual average maximum daily air temperature of about $56^{\circ} \mathrm{F}$.

The National Secondary Drinking Water Regulations for public water systems list maximum contaminant concentrations as follows:

Contaminant
Chloride
Color
Copper
Corrosivity
Dissolved solids
Foaming agents
Hydrogen sulfide
Iron
Manganese
Odor
pH
Sulfate
Zinc

\begin{tabular}{ll}
\multicolumn{2}{l}{ Concentration } \\
250 & $\mathrm{mg} / \mathrm{L}$ \\
15 & Color Units \\
1,000 & $\mu \mathrm{g} / \mathrm{L}$ \\
& $\mathrm{Non}-$ corrosive \\
500 & $\mathrm{mg} / \mathrm{L}$ \\
0.5 & $\mathrm{mg} / \mathrm{L}$ \\
0.05 & $\mathrm{mg} / \mathrm{L}$ \\
300 & $\mu \mathrm{L} / \mathrm{L}$ \\
50 & $\mu g / \mathrm{L}$ \\
3 & $\mathrm{Threshold}$ odor number \\
$6.8-8.5$ & \\
250 & $\mathrm{mg} / \mathrm{L}$ \\
5,000 & $\mu \mathrm{g} / \mathrm{L}$
\end{tabular}


The primary regulations seek to make drinking water safe, whereas the secondary regulations tend to insure that the water will be pleasant to drink as well as suitable for domestic use. Health considerations also were used in formulating the secondary regulations, but to a much lesser extent.

Dissolved solids and sulfate are two constituents included in the secondary drinking-water regulations which have particular relevance to Wyoming waters. Both merit additional discussion for this reason. Hardness and sodium, not included in either the primary or secondary regulations, also are discussed briefly.

Consumer acceptance of drinking water decreases with increasing mineralization (Bruvold, 1967, p.579). Excessive hardness, laxative property, taste, scaling, and corrosion are common problems of excessively mineralized water. Dissolved solids can be removed by distillation, reverse osmosis, electrodialysis, and other methods by treatment plants, but only at considerable expense. The outdated 1962 Drinking Water Standards (U.S. Public Health Service, 1962) set a maximum of $500 \mathrm{mg} / \mathrm{L}$ dissolved solids, or $1,000 \mathrm{mg} / \mathrm{L}$ if no other source was available, as is commonly true in the arid West. Transients have the most difficulty adjusting to a mineralized drinking-water supply as opposed to the resident population who may acquire a taste and tolerance for their local water.

Sulfate may cause taste problems at concentrations of more than $300 \mathrm{mg} / \mathrm{L}$. Scaling in boilers due to excessive concentrations of sulfate is also a problem. At concentrations greater than $600 \mathrm{mg} / \mathrm{L}$, sulfate may have a laxative effect, although individuals normally adjust rapidly to these sulfate concentrations. Transients are often inconvenienced, and for this reason the U.S. Environmental Protection Agency recommends that the States monitor sulfate and advise transients if the sulfate concentration is excessive.

Hardness is important because of its esthetic and economic effects in domestic use. Although soft water is desirable from a nonhealth standpoint, studies have correlated the incidence of heart disease with soft drinking water. Softening of drinking water is therefore being discouraged by some scientists and physicians (U.S. Environmental Protection Agency, 1977, p. 17145). The consideration for inclusion of hardness in the Federal drinking water regulations was rejected on this basis.

The U.S. Geological Survey classifies hardness as follows:

$\begin{array}{cl}\begin{array}{c}\text { Hardness range } \\ \text { (milligrams per liter } \\ \text { as calcium carbonate) }\end{array} & \begin{array}{c}\text { Hardness } \\ \text { description }\end{array} \\ 0-60 & \text { soft } \\ 61-120 & \text { moderately hard } \\ 121-180 & \text { hard } \\ \text { more than } 180 & \text { very hard }\end{array}$


Sodium was considered for the primary regulations for health reasons. Existing data did not, however, support the establishment of a maximum contaminant concentration. The U.S. Environmental Protection Agency recommends that States monitor the sodium concentration of drinking water and advise physicians and consumers of the sodium concentration. Those affected by relatively large sodium concentrations can seek an alternative source of water if necessary.

The above discussion of water-quality criteria for the several uses mentioned is by no means complete or even a complete summary. It is rather a brief discussion of some of the more important criteria with particular relevance to this area.

\section{Surface-Water Quality}

In order to define the chemical quality of upper Separation Creek areally, a network of sampling sites was selected as shown in figure 9 . Most sites are designated by the letter " $S$ " followed by the downstream distance from the stream divide.

Seasonal sampling was done in downstream order at the sites to establish both temporal and areal variation in surface-water quality. A specificconductance monitor was installed at S-29 in order to define temporal variations in quality. The hourly specific-conductance measurements taken by the monitor showed the effects of both snowmelt and rainfall runoff on quality. Data obtained during the study indicated the quality under nearnormal runoff conditions (1976 water year) and the quality resulting from much-below-normal runoff conditions (1977 water year).

\section{Dissolved-Solids Concentration}

The dissolved-solids concentration may be determined in the laboratory by drying a sample on a steam bath, heating the residue for 2 hours at $180^{\circ} \mathrm{C}$, then weighing the residue. During this process all bicarbonate salts are converted to carbonate. A second method determines the dissolved-solids concentration by adding the concentration of the major ions and silica. (An ion is an electrically charged atom or group of atoms into which salts tend to dissociate when dissolved in water.) An equivalent concentration of carbonate is used instead of bicarbonate in summing the constituents, so that the results of the two methods are comparable.

Specific conductance is useful in estimating the dissolved-solids concentration of water. The specific conductance of water is the electrical conductivity (the reciprocal of the resistance in ohms) measured between opposite faces of a 1-centimeter cube of the water sample at a specified temperature. The unit of measurement is the micromho ( $\mu$ mho) and $25^{\circ} \mathrm{C}$ is the standard temperature to which all conductivity data has been converted to in this report. 
A good relation commonly can be determined between specific conductance and the dissolved-solids concentration for an individual stream or reach of a stream. Once this relation is established, a simple on-site measurement of specific conductance can provide a fast, convenient method for estimating the dissolved-solids concentration.

To determine the relation between the specific conductance and the dissolved-solids concentration of water in upper Separation Creek, 44 data pairs of specific-conductance measurements and dissolved-solids concentrations were used in a regression analysis. The data pairs were obtained from water at the sampling sites along the entire reach of stream under study at various times during the period of streamflow. For this stream, the regression analysis (fig. 17) yielded the following relation:

where

$$
\mathrm{DS}=0.77 \mathrm{~K}-71
$$

$$
\begin{aligned}
\mathrm{DS} & =\text { dissolved-solids concentration, in milligrams per liter; and } \\
\mathrm{K} & =\text { specific conductance, in micromhos per centimeter at } 25^{\circ} \text { Celsius }
\end{aligned}
$$

The correlation coefficient is 0.991 . For specific-conductance values as much as $2,000 \mu \mathrm{mho}$, estimates of the dissolved-solids concentration should be reasonably accurate.

Specific conductance values and dissolved-solids concentrations for the periods of flow at station $\mathrm{S}-29$ are shown in figure 18 . The tenfold variation in range between the largest and smallest concentrations along with the rapid rate of change are both strikingly evident. The specificconductance graph for the 1976 water year indicates extremes of less than $100 \mathrm{mg} / \mathrm{L}$ to more than $1,500 \mathrm{mg} / \mathrm{L}$ of dissolved solids with an average of about $700 \mathrm{mg} / \mathrm{L}$. During the 1977 water year, the smallest concentration was about $1,000 \mathrm{mg} / \mathrm{L}$ of dissolved solids. The greatest specific-conductance values exceeded the $2,500-\mu$ mho limit of the monitor.

Periodic flushing of accumulated salts accounts for much of the variation in the dissolved-solids concentration of upper Separation Creek. The effects of flushing can readily be seen in figure 19. Rainfall more than tripled the stream discharge between June 12 and June 16, 1976, and the specific conductance increased from about $700 \mu \mathrm{mho}$ to more than 1,200 $\mu$ mho for the same period. Rainfa11 both on June 18 and on June 22, 1976, increased the specific conductance of the stream.

Two mechanisms are believed primarily involved in the flushing process: (1) Runoff from rainfall or snowmelt washes salts directly into the stream, and (2) the rising stream picks up salts that have accumulated along the channel banks. Bank storage of salts results from banks taking up stream water by capillary action. Subsequent evaporation produces a salt residue commonly seen as salt crystals inches above the water surface. Flow from seeps or springs evaporates before reaching the stream channel, leaving a considerable salt load on or near the ground surface. This latter process was evident at the saline springs downstream from the mouth of Jep Canyon. 


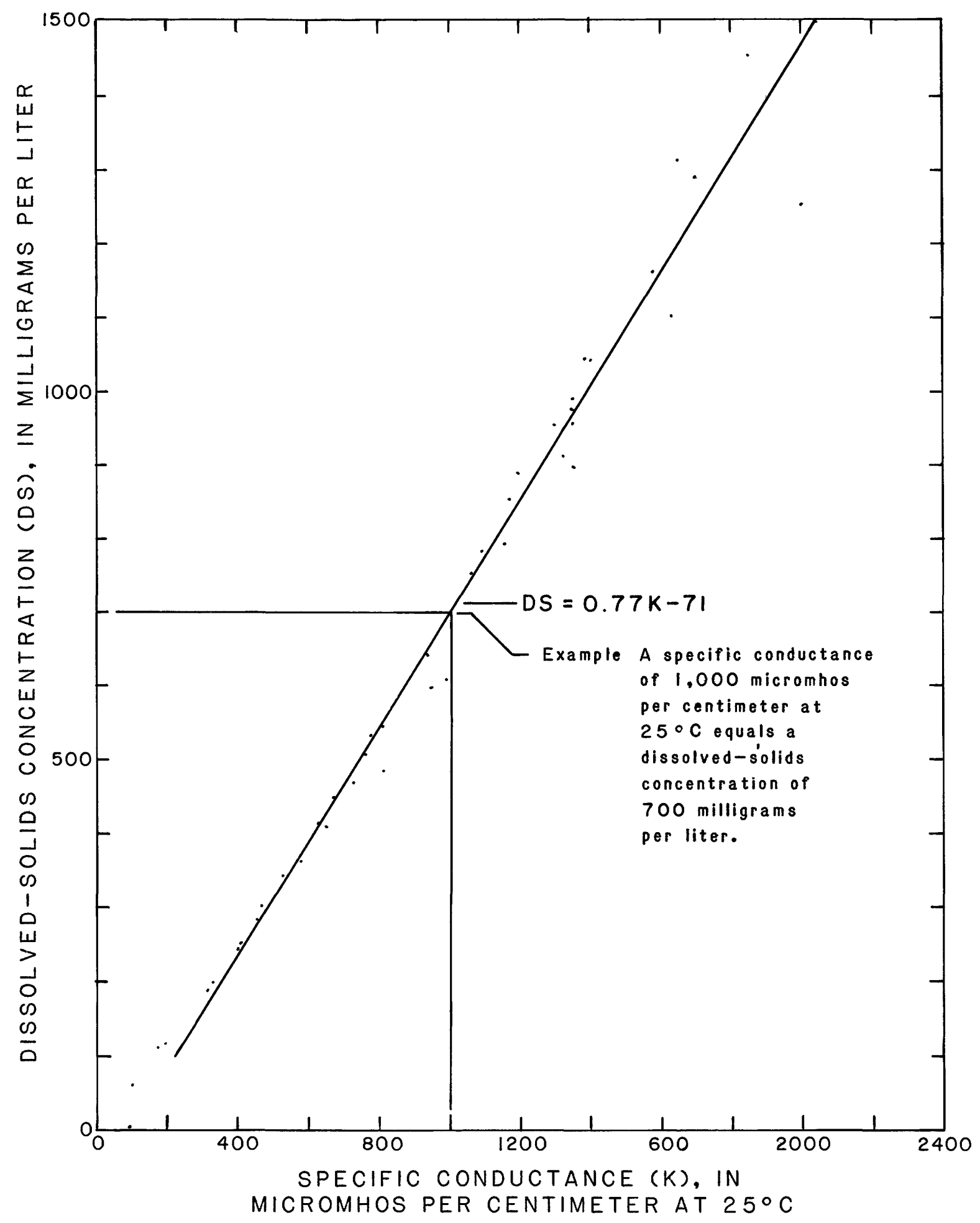

Figure 17.--Specific conductance can be used to estimate the dissolved-solids concentration of upper Separation Creek. 


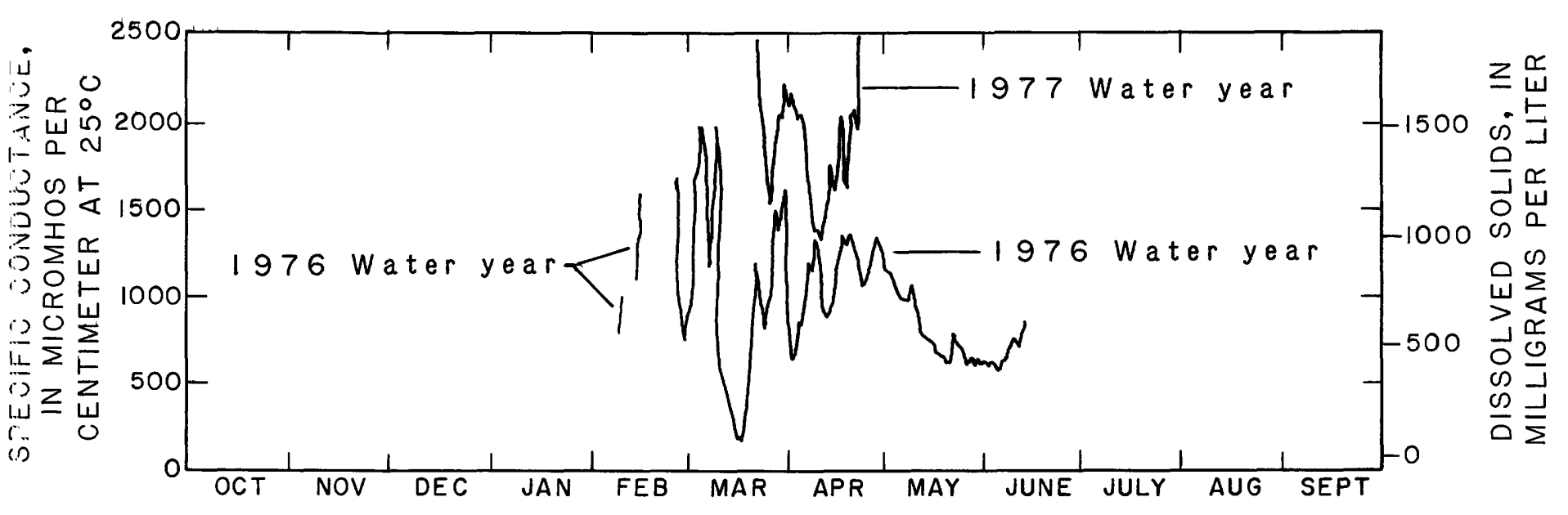

Figure 18.--Daily specific conductances at site S-29 during 1976 and 1977 water years show an increase in specific conductance and dissolved-solids concentration during the 1977 runoff. 


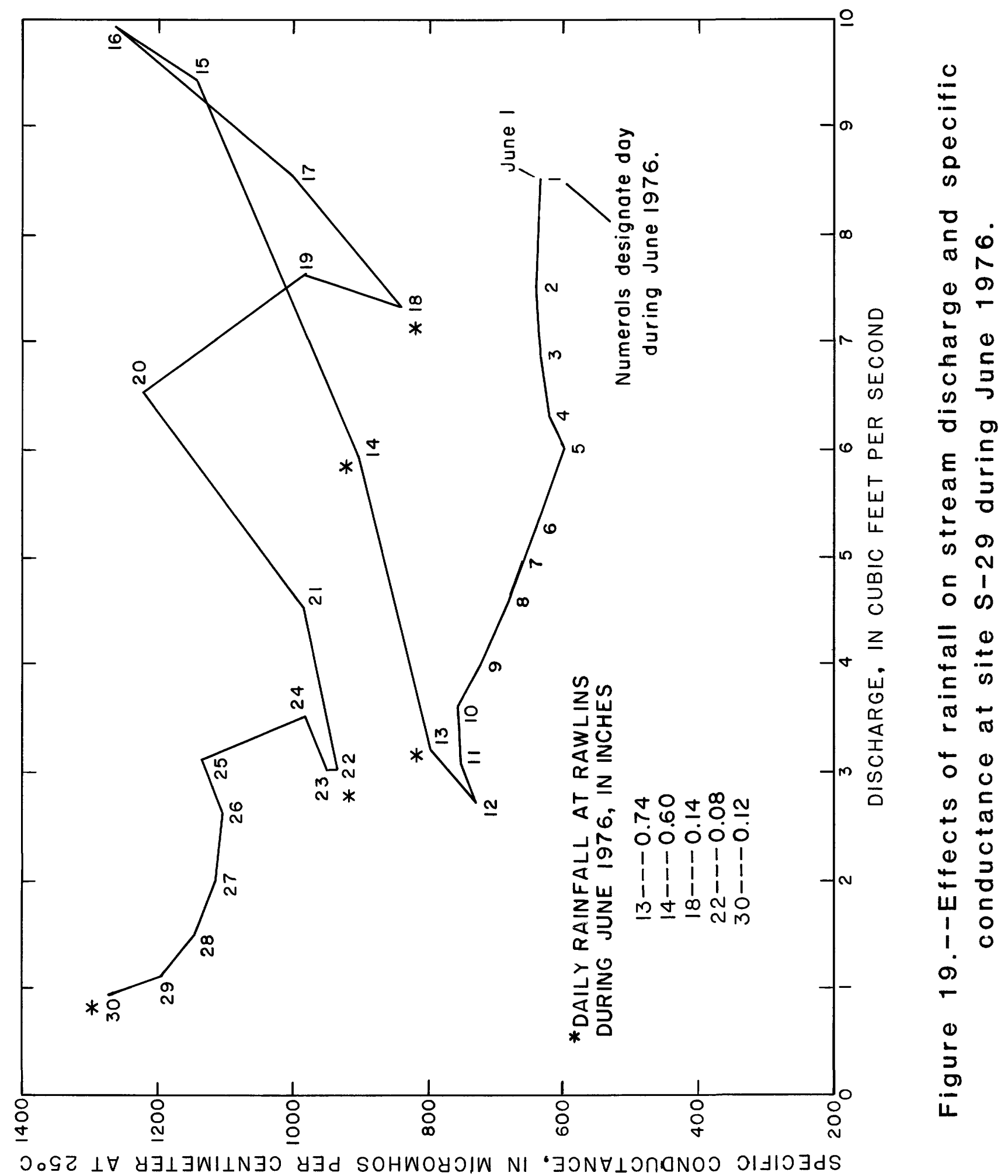


In less arid areas more frequent flushing and less evaporation coupled with more substantial baseflow would make flushing much less significant.

In addition to the wide range and sharp fluctuations in the dissolvedsolids concentration, figure 18 shows the decrease in quality resulting from the snow drought of the 1977 water year at site S-29. Quality as well as quantity decreased. A comparison of specific conductance between May 12-13, 1976, and May 25-26, 1977, (fig. 20) shows significant deterioration in quality (as reflected by the increase in specific conductance) for the entire stream reach in the study area. During May 25-26, 1977, the specific conductance nearly doubled between sites S-6 and site S-14. A fourfold increase in specific conductance occurred from the headwaters to the point where the streamflow ceased at mile 26 .

Specific conductance generally increased downstream as shown in figure 21. During May 12-13, 1976, specific conductance ranged from $175 \mu$ mho at site S-6 to 1,350 mho at site S-41. The effect of snowmelt entering from tributaries at lower elevations and diluting the dissolved-solids concentration is shown by the result of the March 29, 1976, sampling. The discharge graph in figure 21 shows that on March 29, 1976, most of the water entered Separation Creek between site $\mathrm{S}-20$ and site S-29. Very little snowmelt was originating from the higher elevations. On September 2, 1976, the rate of increase in specific conductance with downstream distance was greatest; however, streamflow was not continuous downstream from mile 14.

Considerable seasonal variation in specific conductance also is shown in figure 21. The 1976 specific-conductance values at site S-6 ranged from 175 umho during May 12-13 to 580 umho on March 29. Even greater seasonal variations are evident in the middle reaches.

The cumulative ionic compositions of the water along the creek during a period of high flow in May 1976 and during a period of low flow in July 1976 are shown in figure 22. During both periods, calcium was the dominant cation in the headwaters and magnesium was dominant farther downstream. Downstream increases in sodium and potassium ions, as a group, were discernible. Bicarbonate and carbonate anions dominated in the headwaters. Concentrations of these ions remained about constant while sulfate ion concentration increased resulting in its dominance farther downstream. Fluoride, chloride, and nitratenitrogen changed little throughout the entire reach.

Despite the limitations for some uses, upper Separation Creek water is very satisfactory for its present uses--the watering of livestock and wildlife and the irrigation of native hay. Chemical analyses for surface water are shown in table 3. No particular ion concentration indicates a problem other than hardness. The dissolved-solids concentration would make the water undesirable for some uses in the downstream reaches, especially during periods of low flow. Surface water upstream from site S-14 contains less than $500 \mathrm{mg} / \mathrm{L}$ of dissolved solids and is suitable for most uses including raw water for a municipal supply. 


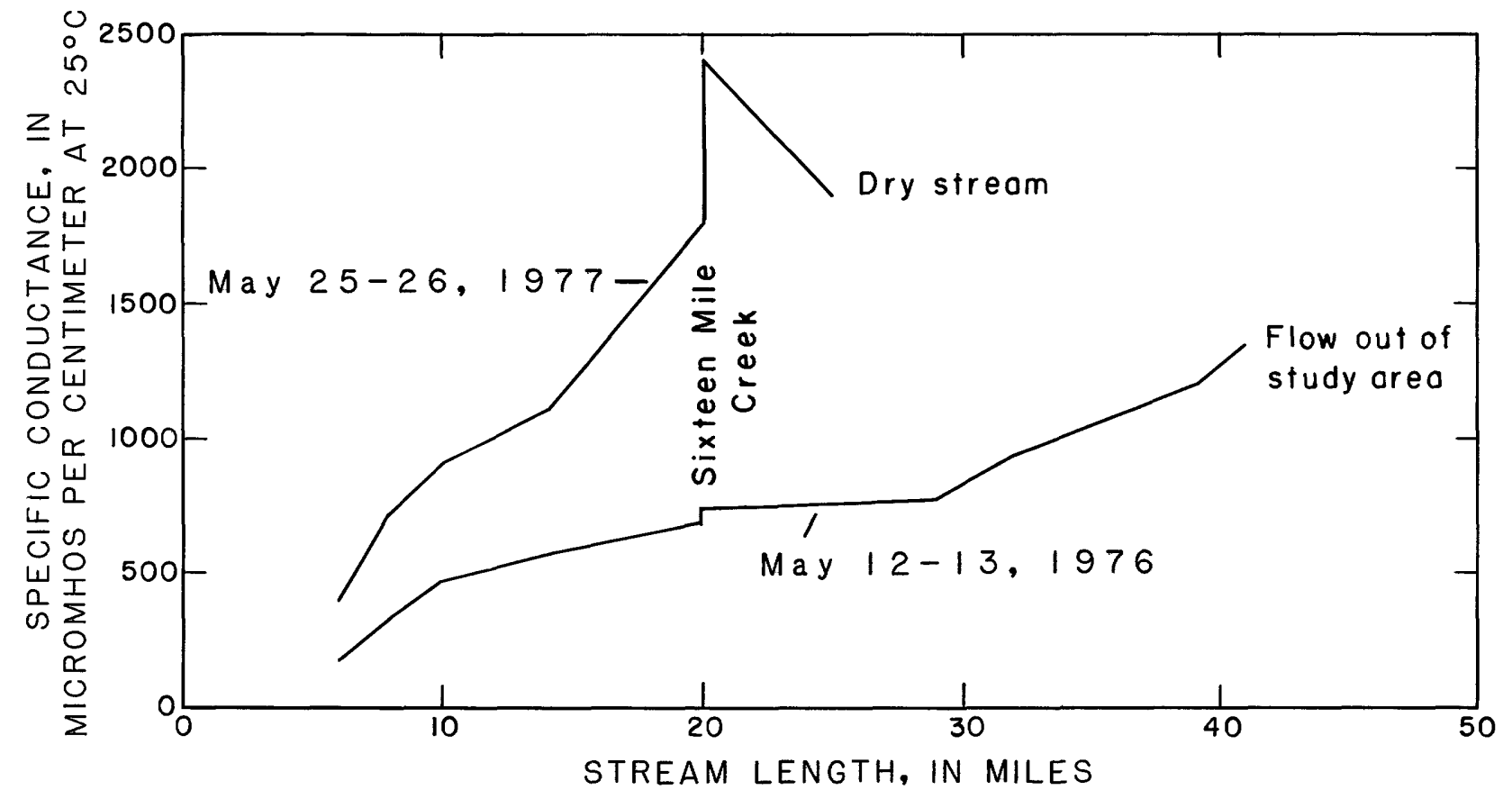

Figure 20.--Comparison of specific conductance for upper Separation Creek between May 1976 and May 1977 shows an increase in specific conductance during May 1977. 

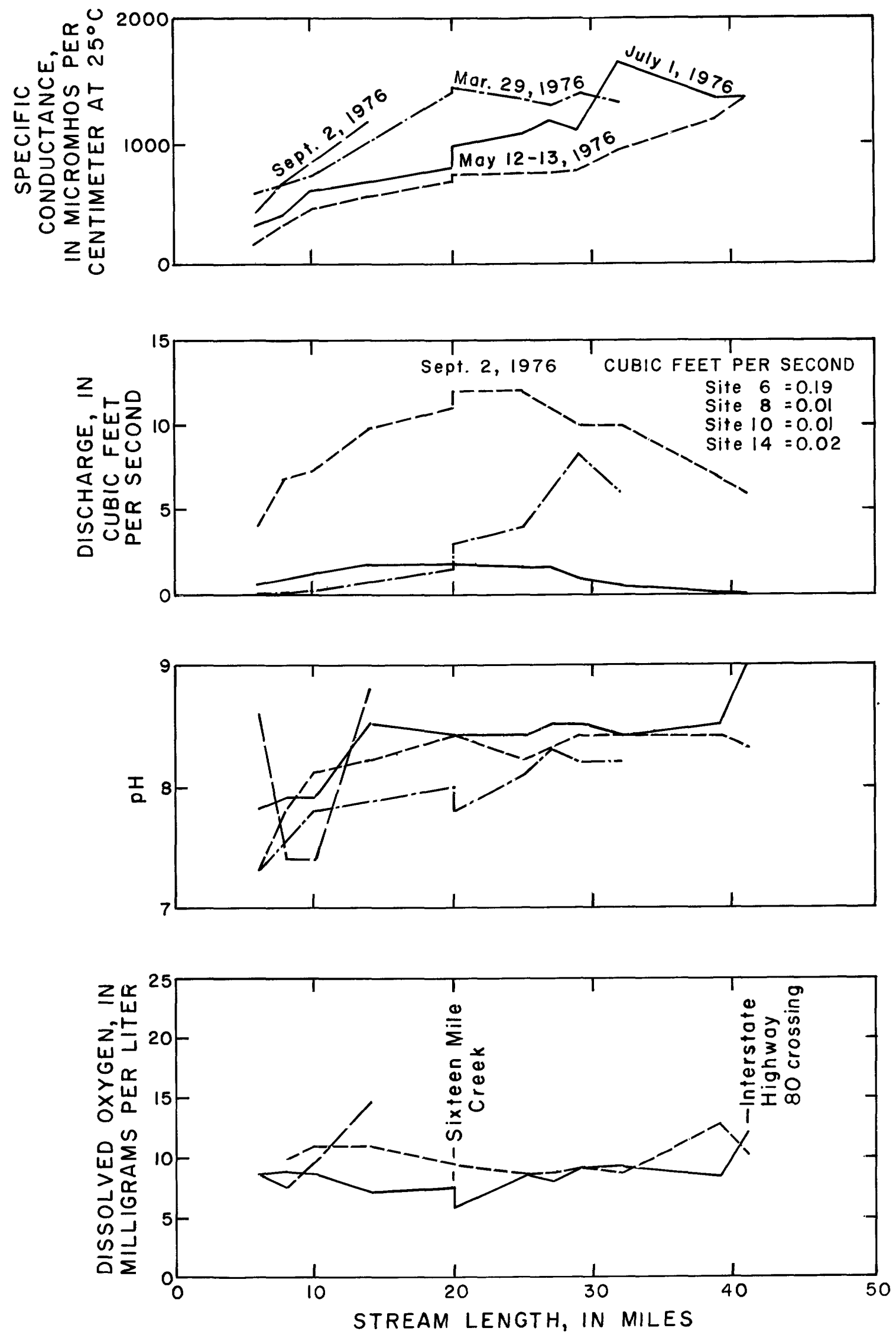

Figure 21.--Areal and temporal variations of specific conductance, discharge, $\mathrm{pH}$, and dissolved oxygen for upper Separation Creek. 

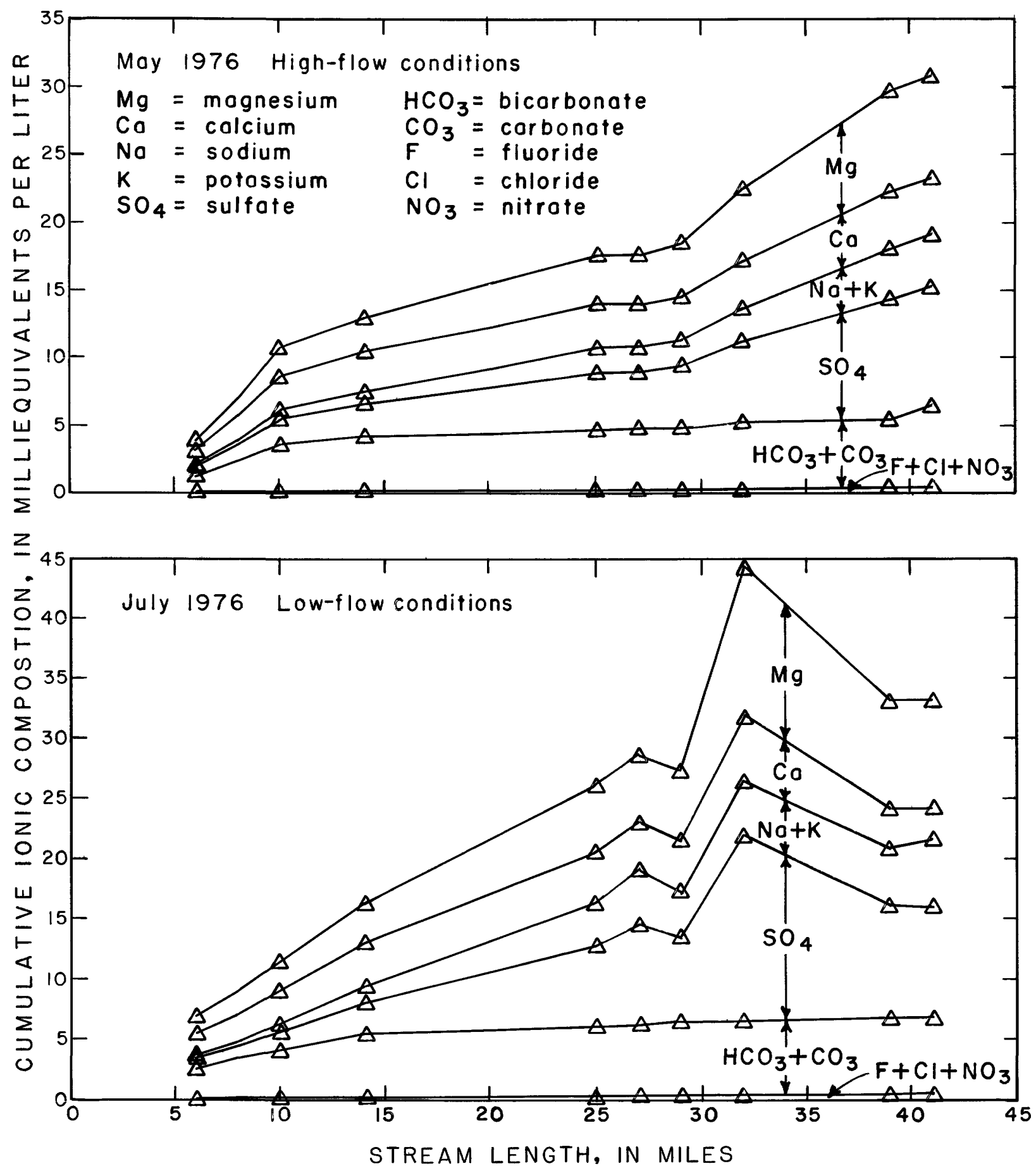

Figure 22.--Cumulative ionic composition of water during high- and low-flow conditions of upper Separation Creek. 


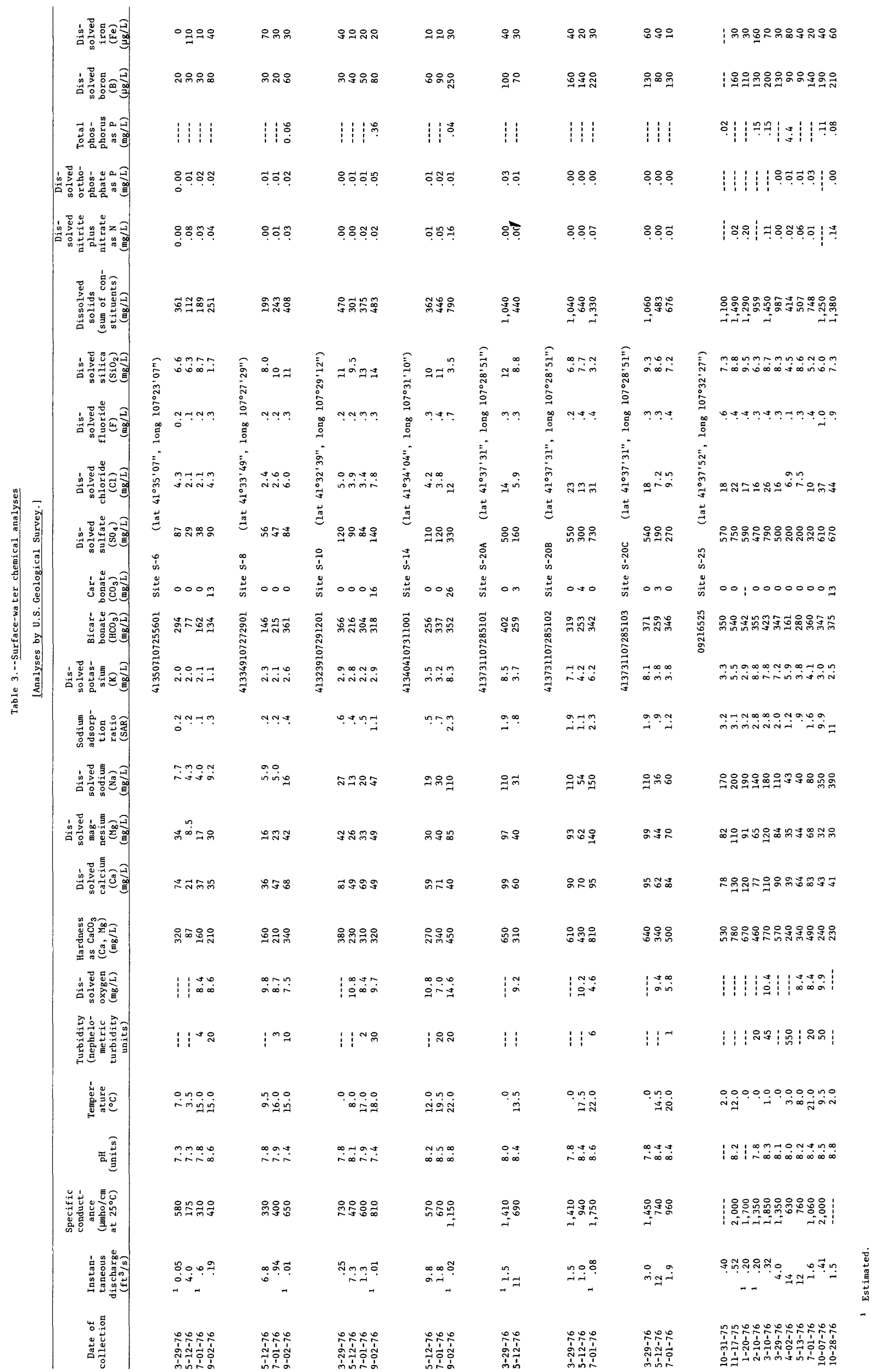




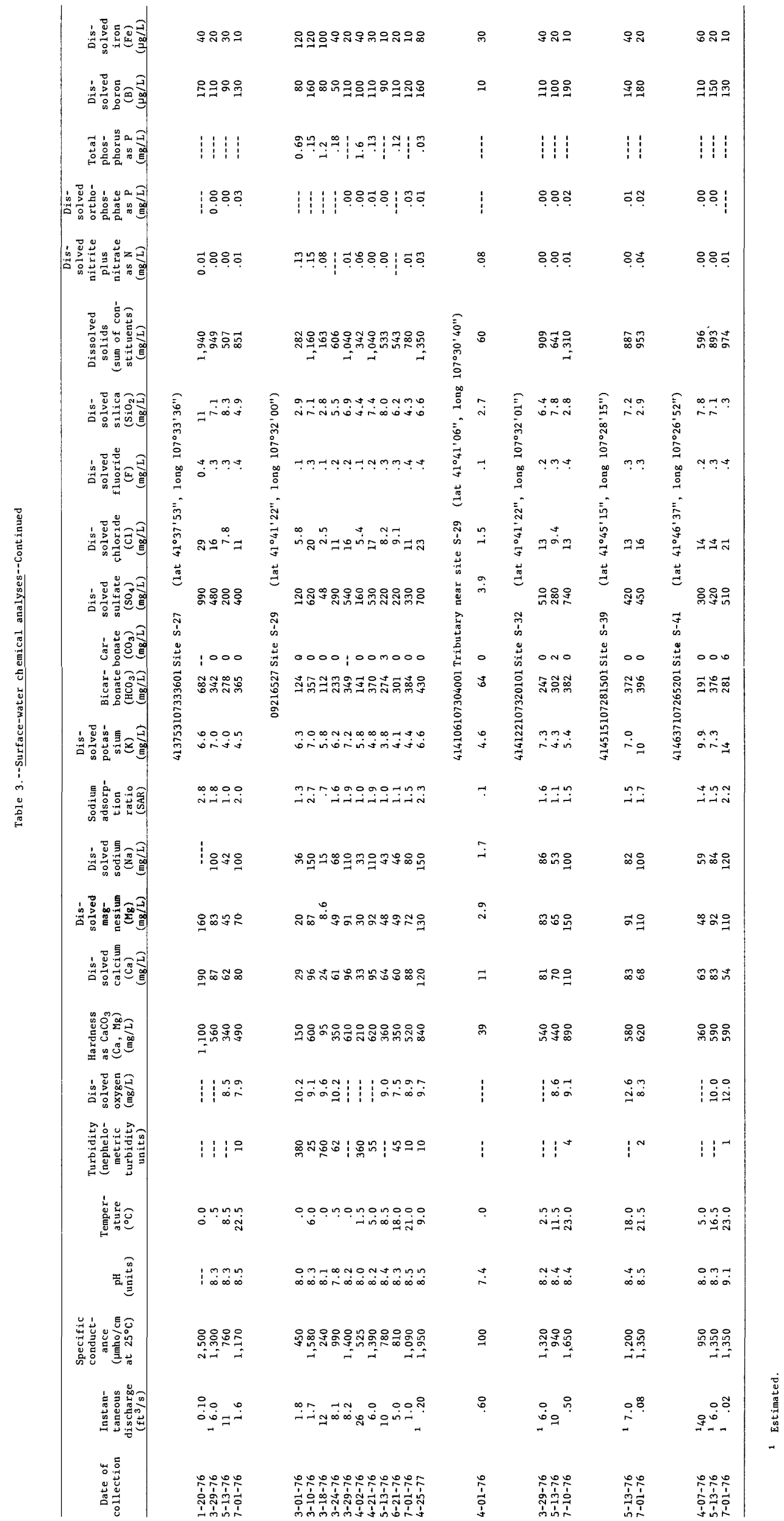


A histogram (fig. 23) shows measured $\mathrm{pH}$ values in upper Separation Creek ranging from 7.3 to 9.1. A natural diurnal fluctuation in pH exists as a result of the use of carbon dioxide through photosynthesis by algae in the stream during daylight hours which tends to increase the $\mathrm{pH}$. The $\mathrm{pH}$ values were measured during daylight hours and are biased accordingly. A synoptic view of $\mathrm{pH}$ for upper Separation Creek is given in figure 21 . The $\mathrm{pH}$ values increase downstream to the middle reach where the values tend to stabilize. The largest values occurred on July 1, 1976, when photosynthesis was large.

\section{Dissolved Oxygen}

The range in the dissolved-oxygen concentrations from measurements made along the entire study reach of the creek is shown in the histogram in figure 24. Dissolved oxygen ranged from 5 to $15 \mathrm{mg} / \mathrm{L}$. The large value at site S-14 on September 2, 1976, resulted from supersaturation by photosynthesis from a dense algal mat upstream.

Areal and seasonal variations in dissolved oxygen are shown in figure 21. Because fish are not present in the stream, a diurnal dissolved-oxygen study was not undertaken. Lack of water would be more critical to fish than the dissolved-oxygen concentration.

\section{Trace Metals and Radioactive Substances}

The dissolved trace-metal concentrations in Separation Creek (table 4) were less than current drinking-water standards. The relatively large $\mathrm{pH}$ and alkalinity of the stream are natural controls on the solubility of these trace metals. The radiochemical analyses (table 5) indicate the absence of unusually large concentrations of radioactive substances.

\section{Suspended Sediment}

The suspended-sediment load calculated at site S-29 for the 1976 water year was 902 tons. Due to the fine nature of the sediment, this figure approximates the total load, as very little coarse material is available for transport as bed load.

The suspended-sediment yield for the 55 square miles of drainage upstream from site $\mathrm{s}-29$ was 16 tons per square mile during the 1976 water year. This is a relatively small yield compared with other Wyoming basins. This 1-year period of record is of little value in ascertaining the average annual yield of the basin because a thousandfold variation in total sediment yield from one year to the next has been measured in some streams.

The relatively small sediment yield for the 1976 water year can be attributed to the following factors: (1) Only two rainstorms produced significant runoff during the year; (2) beaver dams in the upstream reaches act as sediment traps for the southern part of the basin; (3) the channel is relatively stable, acting primarily as a carrier rather than a contributor to the sediment load; and (4) the vegetal cover in the headwaters area tends to hold the soil and reduce the sediment yield from this area. 


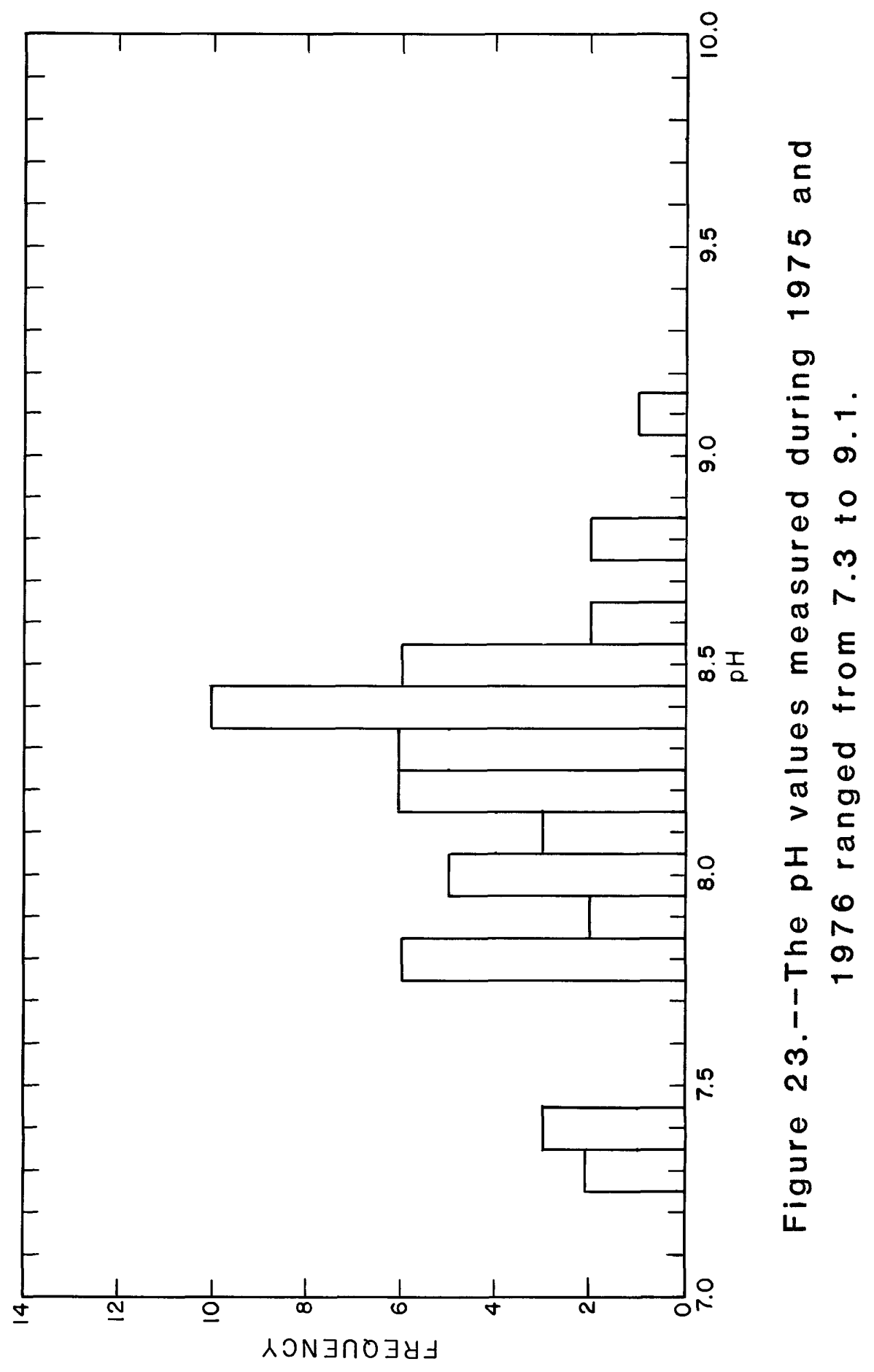




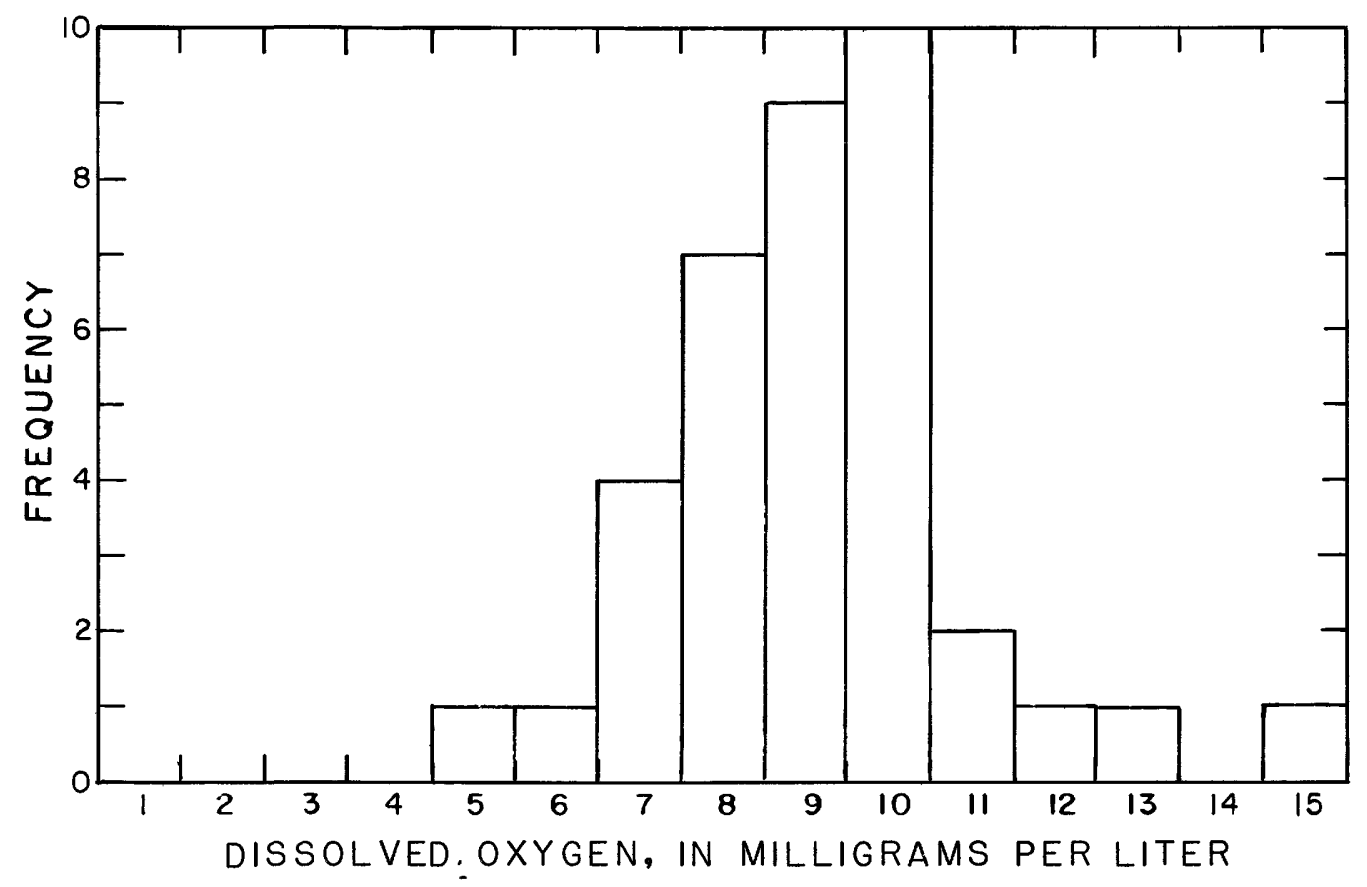

Figure 24.--The dissolved-oxygen concentrations measured during 1975 and 1976 ranged from 5 to 15 milligrams per liter. 


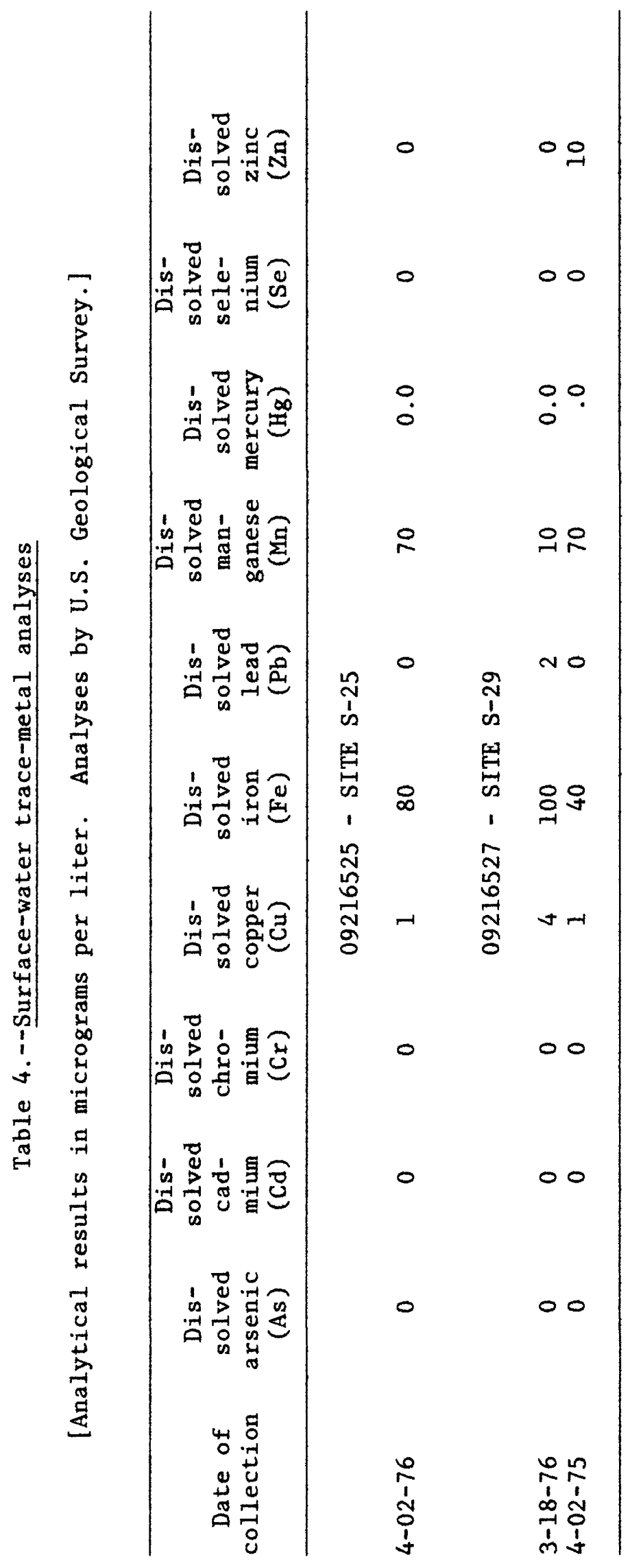




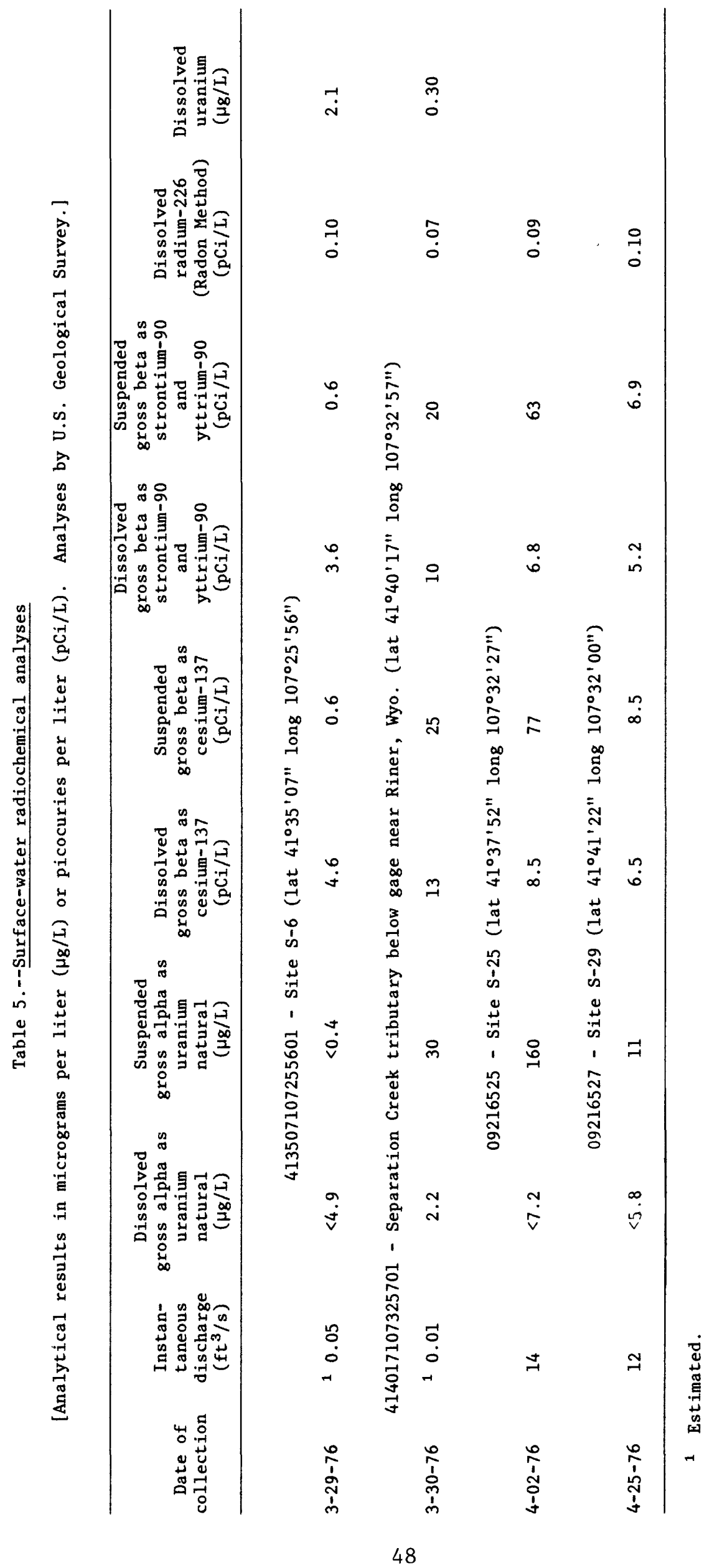


Daily sediment concentrations for the period of flow during the 1976 water year ranged from $34 \mathrm{mg} / \mathrm{L}$ on July 11 to $11,900 \mathrm{mg} / \mathrm{L}$ on July 27 as shown in figure 25. A rainstorm produced the largest daily load of 70 tons on July 27, with an average discharge on this date of about $1 \mathrm{ft}^{3} / \mathrm{s}$. This sediment load was twice as great as the load on the day with the greatest daily discharge $\left(25 \mathrm{ft}^{3} / \mathrm{s}\right)$, produced solely by snowmelt. The marked difference between sediment concentrations produced by snowmelt and those produced by rainstorm runoff indicates that larger sediment loads would be produced by a severe rainstorm.

The relation of snowmelt-induced discharge to suspended-sediment load at site S-29 is shown in figure 26. A similar relation was found at site S-25. Flow resulting largely from rainfall would probably have a very different relation, but data were not available to show this.

\section{Biota}

Stream habitat and environmental stability are two important factors that may affect the biota of upper Separation Creek; of lesser importance is the chemical quality of the water. All three factors vary considerably with time and space.

Three distinct types of habitat exist in upper Separation Creek. The first, or upstream reach, extends from the headwaters to site S-14. The second, or middle reach, extends from site S-14 to site S-39. The third, or downstream reach, extends from site S-39 to the boundary of the study area and beyond.

The upstream reach in Jep Canyon is characterized by clear water, springs, ponds, and varying bed material in the stream channel (where it is not flooded by beaver ponds). This reach generally has the lowest dissolved-solids concentration, average velocity, turbidity, and water temperature of the three reaches. Streamflow, temperature, sediment concentration, and stream banks generally also are more stable here than in the other two reaches.

Beaver have greatly affected the creek habitat within Jep Canyon. Stream gradient is greatest on this upstream reach; however, the beaver have altered the stream channel into a series of ponds for much of its length. These ponds act as sediment traps reducing the turbidity of the water, which results in increased light penetration. Shading of the stream has been greatly reduced due to the appetite of beaver for aspens and willows, both of which are abundant in Jep Canyon. Beaver bring into the stream a large amount of organic matter which supplies food for many organisms.

The springs and seeps in Jep Canyon, although not able to sustain streamflow throughout the year, are nevertheless able to sustain many of the beaver ponds. These ponds, along with the springs, maintain the only continuously wet environment necessary for the survival of many aquatic organisms when other reaches of the creek are dry. These wet areas in Jep Canyon serve as repopulation bases for the creek when streamflow resumes in the spring. 

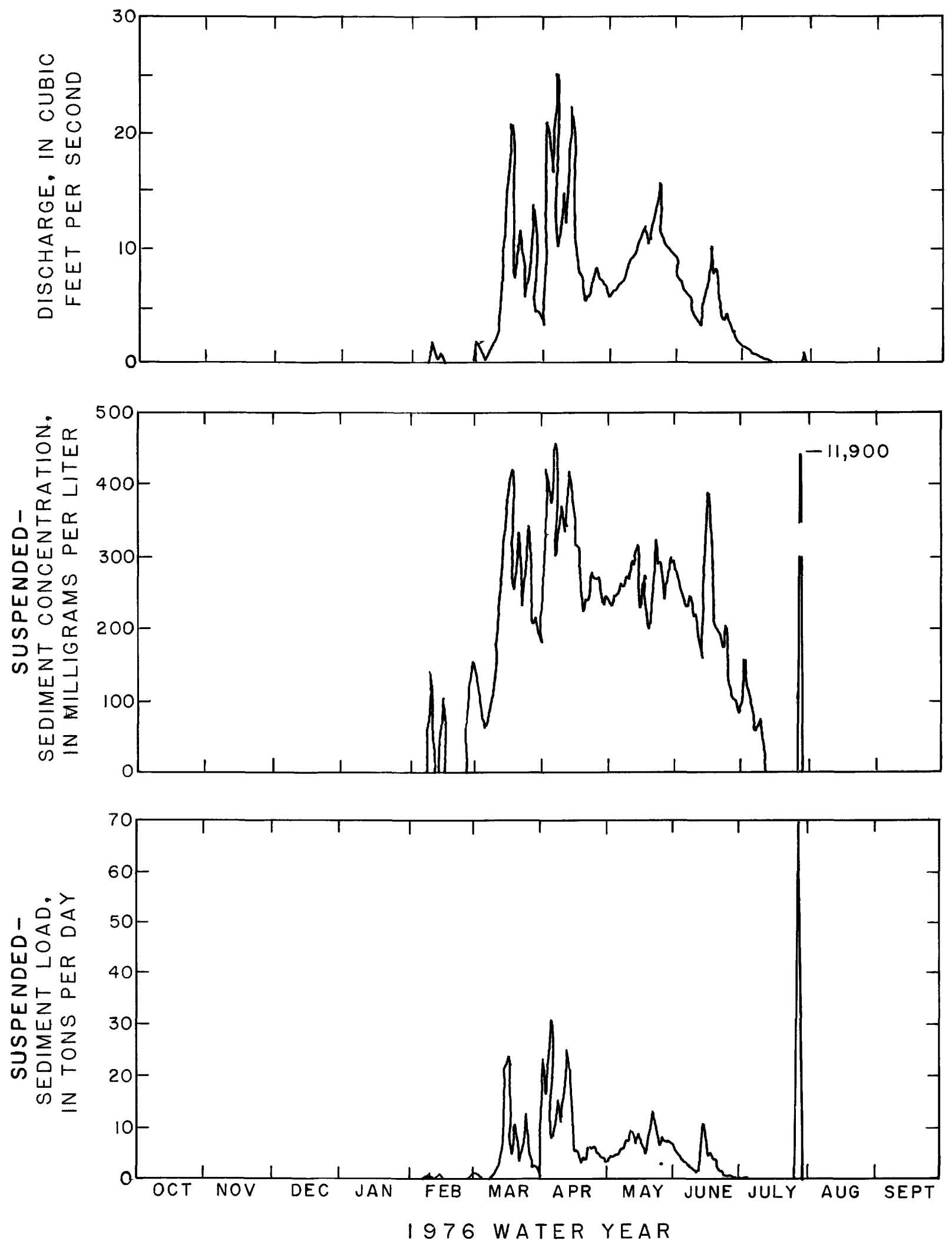

Figure 25.--Daily discharge, suspended-sediment concentration, and suspended-sediment load at site S-29 for 1976 water year. 


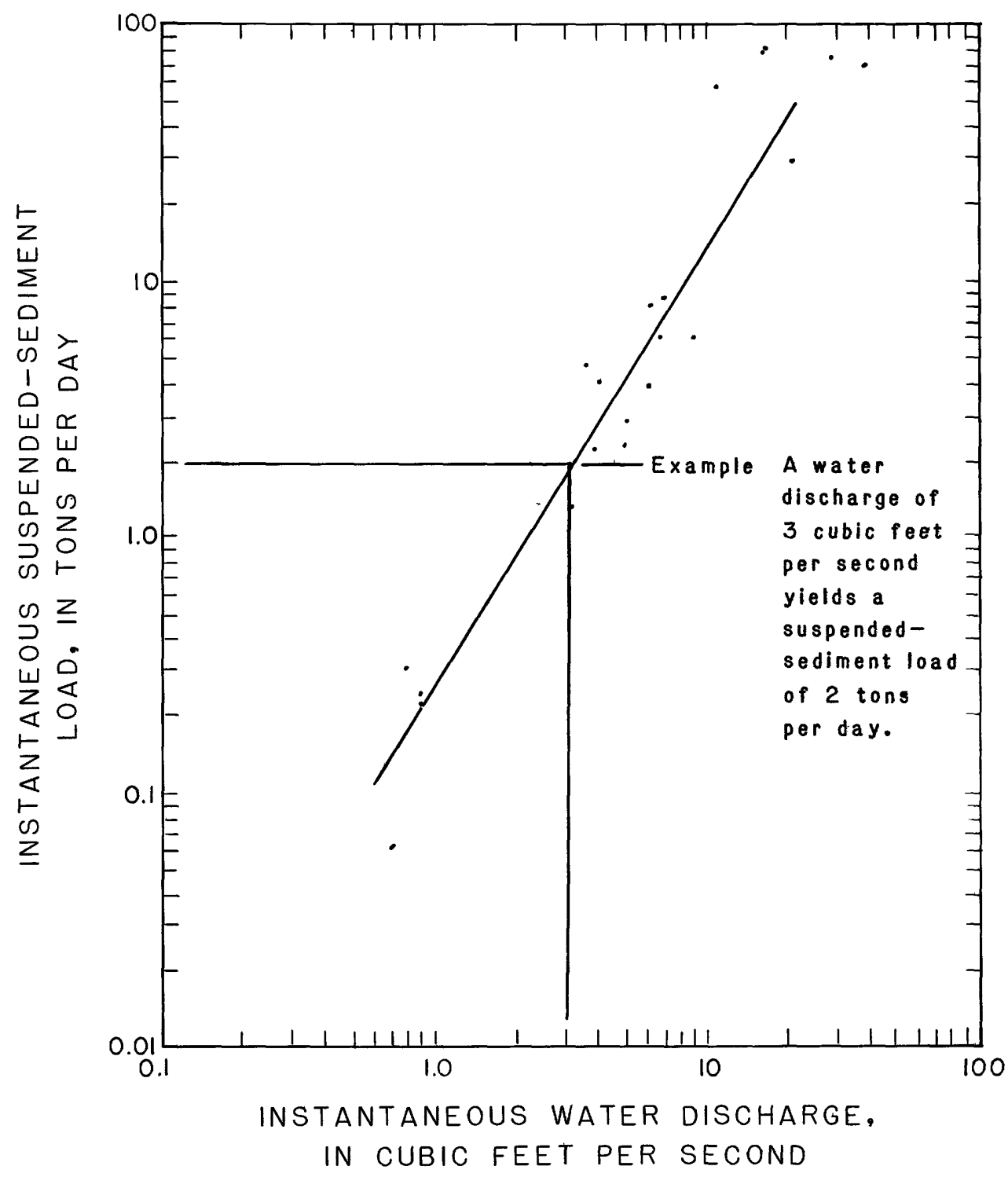

Figure 26.--The suspended-sediment load may be predicted from the snowmelt-induced discharge at site S-29. 
Relatively small phosphorus concentrations may seasonally limit algal productivity in this reach. Algal growth potentials based on phosphorus concentrations in samples from sites S-6 and S-10 during March 1976 were zero. Samples from the same sites and on the same date that were spiked with phosphorus showed large algal growth potential indicating this to be a limiting nutrient. Samples collected at the same sites during May and September 1976 showed larger algal growth potentials, and phosphorus concentrations ranged from 3.2 to $8.3 \mathrm{mg} / \mathrm{L}$.

The middle reach is characterized by turbid water, faster stream velocities than the upstream reach, and a soft, uniformly fine-grained alluvial material composing the streambed. Streamflow conditions are less stable than in the upstream reach. Limited light penetration and an unstable streambed provide an inhospitable environment for both phytoplankton and periphyton making primary productivity in this reach the least of the three reaches described.

The downstream reach is characterized by slower stream velocities, less turbid water, warmer temperatures, and greater dissolved-solids concentrations than in the middle reach. The streambed consisting of sand, clay, and gravel offers more diverse substrata than found in the middle reach. Streamflow in the downstream reach has the shortest duration, water temperature is warmest, and the dissolved-solids concentration is the greatest of the reaches described. Productivity, although not measured, was observed to be relatively large before this reach dried up in the summer of 1976 .

Most biological samples were collected during 1976 in grab samples along the study reach. Sampling results are considered qualitative rather than quantitive.

Periphyton and phytoplankton found in the entire study reach are listed in table 6. Periphyton are the attached organisms, both plant and animal; however, only the algal part of the periphyton community was identified. The phytoplankton include all suspended and floating algae and detached periphyton.

Benthic invertebrates found in upper Separation Creek are listed in table 7. Benthic invertebrates are the group of animals without backbones which live in or on the bottom of an aquatic environment.

The periphyton and benthic-invertebrate communities are good indicators of water quality at the sampling sites. Both communities respond to the physical and chemical conditions to which they are exposed. With their limited mobility and relatively long life spans, the periphyton amd benthicinvertebrate communities give an integrated indication of the water quality at a site. In a stream the phytoplankton are transitory, subject to natural temporal variations, and are dependent on upstream environmental factors that do not necessarily reflect the conditions at the sampling site. Phytoplankton are therefore not considered to be indicators of water quality for a specific stream site. 
Table 6.--Periphyton and phytoplankton 1ist by genera

\section{Periphyton \\ Green algae \\ Ankistrodesmus \\ Mougeotia \\ Spirogyra \\ Ulothrix}

Blue-green algae

Anabaena

Lyngbya

Oscillatoria

Diatoms

Achnanthes

Amphora

Caloneis

Cocconeis

Cymatopleura

Cymbella

Diploneis

Epithemia

Fragilaria

Gomphonema

Gyrosigma

Hantzschia

Meridion

$\overline{\text { Navicula }}$

Nitzschia

Pinnularia

Rhoiocosphenia

Rhopalodia

Stauroneis

Surirella

Synedra

Euglenoids

Euglena

Flagellates

Tribonema
Phytoplankton

Green algae

Ankistrodesmus

Carteria

Chlamydomonas

Chlorella

Cosmarium

Scenedesmus

Spaerellopis

Blue-green algae

Anabaena

Anacystis

Lyngbya

Oscillatoria

Diatoms

Achnanthes

Amphiprora

Amphora

Cyclotella

Cymbella

Epithemia

Fragilaria

Gomphonema

Gyrosigma

Hantzschia

Melosira

Meridion

Navicula

Nitzschia

Pinnularia

Rhoiocosphenia

Rhopalodia

Euglenoids

Euglena

Trachelomonas 
Table 7.--Benthic invertebrates by family

Benthic invertebrates

$\begin{array}{ll}\text { Agrionidae (dragonfly) } & \text { Gerridae (water strider) } \\ \text { Baetidae (mayfly) } & \text { Glossiphoniidae (leech) } \\ \text { Ceratopogonidae (biting midge) } & \text { Hydracarina (mite) } \\ \text { Chironomidae (midge) } & \text { Limnephilidae (caddis fly) } \\ \text { Corixidae (water boatman) } & \text { Perlodidae (stone fly) } \\ \begin{array}{l}\text { Culicidae (mosquito and } \\ \text { phantom midge) }\end{array} & \text { Physidae (pouch snail) } \\ \begin{array}{l}\text { Dytiscidae (predaceous } \\ \text { diving beetle) }\end{array} & \text { Sphaeriidae (fingernail clam) } \\ \text { Gammaridae (scud) } & \text { Tipuliidae (crane fly) }\end{array}$


Dominant organisms found in the upper reach were the green algae, Spirogyra and Ulothrix, the diatoms Synedra and Fragilaria, and the flagellate Tribonema. Among the benthic invertebrates, mayfly (Baetidae) and caddis fly (Limnephilidae) nymphs along with scuds (Gammaridae) predominated in the upstream reach.

In the less stable middle and downstream reaches D. J. Wangsness (U.S. Geological Survey, written commun., 1976) observed a succession of dominant organisms. Drift organisms from the upstream reach arrived when streamflow resumed in the spring. The blue-green algae, Oscillatoria and Lynbya, the green algae Ankistrodesmus, and the diatoms Gomphonema and Epithemia developed the first algal succession. This first succession reflects the tolerance for cool' temperatures. With generally warming temperatures and increased dissolved-solids concentrations, the green algae Carteria and Cosmarium, the blue-green algae Anacystis and Anabaena, and the diatom Amphiprora, all proliferated. As streamflow ceased, the Anabaena, capable of fixing atmospheric nitrogen, formed a pure collection in the remaining pools before the pools dried up by late summer.

Benthic invertebrates native to the middle and downstream reaches, such as the predaceous diving beetles (Dystiscidae), the dragonflies (Agrionidae), and the water boatmen (Corixidae), can survive the recurrent dry spells by aestivating in the stream banks and reemerging during the spring runoff. Some benthic organisms emerge as adults before the pools dry up and instinctively fly upstream to the perennial ponds and springs to lay their eggs. Still other insects have drought-resistant eggs that hatch during the following spring runoff.

The concentrations and relative abundance of phytoplankton found in samples collected at 12 sites on May 12 and 13, 1976, are shown in figure 27.

Of the three reaches described, only the upstream reach (in Jep Canyon) and the downstream reach (downstream from site S-39) offer much diversity in habitat for aquatic organisms. Of these two reaches, only the upstream reach offers relatively stable conditions and has a continuously wet environment.

\section{Temperature}

The physical, chemical, and biological properties of water are closely related to temperature as it affects sediment transport, rates of chemical reactions, and biological processes. A temperature monitor recorded hourly temperatures at site S-29, and temperatures also were measured during surface- and ground-water sampling at miscellaneous sites. 


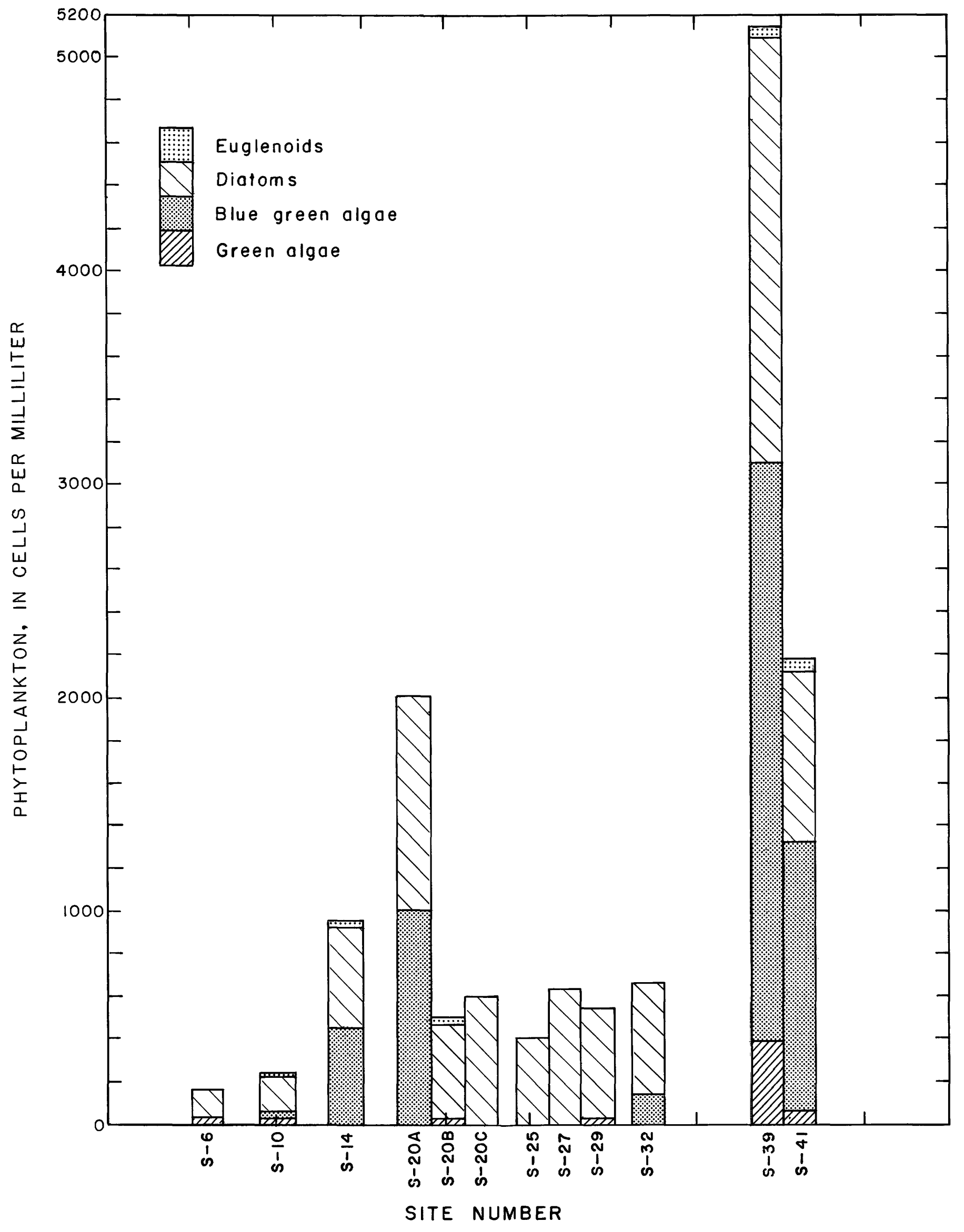

Figure 27.--Relative abundance of phytoplankton in upper Separation Creek, May 12-13,1976 (D. J. Wangsness, U.S. Geological Survey, written commun., 1976). 
A technique developed by Lowham (1978) was used to describe the annual variation of stream temperatures for the study area. The technique uses a regional model for estimating mean daily temperatures of streams at unmeasured sites in the Green River and Great Divide Basins of Wyoming. Annual variation of water temperatures at a given site is described by the harmonic equation:

$$
T(t)=A[\sin (0.0172 t+C)]+M
$$

whe :

$$
\begin{aligned}
T(t)= & \text { stream temperature, in degrees Celsius, on day } t \\
& \text { of the water year (October } 1 \text { is } t=1) ; \\
A & =\text { amplitude of the harmonic, in degrees Celsius; } \\
t & =\text { number of days since September } 30 ; \\
C & =\text { phase angle of the harmonic, in radians; and } \\
M & =\text { mean of the harmonic, in degrees Celsius. }
\end{aligned}
$$

Tin coefficients $A, C$, and $M$ depend on relations determined from the el tion and location of the site (Lowham, 1978, p. 16, 17). Specific va $1 \in 3$ for these coefficients at site $\mathrm{S}-29$ are: $\mathrm{A}=11.0^{\circ} \mathrm{C}, \mathrm{C}=2.68$ radians, and $1=0.6^{\circ} \mathrm{C}$.

Measured daily mean water temperatures at site S-29 are compared with expected water temperatures, as predicted by the harmonic model, in figure 28. A characteristic of shallow, unshaded streams, remote from feeder springs, is the larger diurnal range in temperature, as opposed to larger, relatively deeper streams whose diurnal range in temperature is fairly small. A diurnal fluctuation of 8 to $9^{\circ} \mathrm{C}$ was common at site S-29.

Except for short distances downstream from significant ground-water discharge, water temperature closely approximates air temperature. The relation of the harmonic mean of annual water temperature versus elevation for streams in the Green River and Great Divide Basins is shown in figure 29. A difference of 1,800 feet in elevation accounts for a $3.5^{\circ} \mathrm{C}$ difference in mean temperature between the headwaters and the downstream reach of Separation Creek in the study area.

\section{Ground-Water Quality}

Ground water is used exclusively for livestock and wildlife watering in the upper Separation Creek basin. The water quality is generally adequate for livestock and wildlife use but may be unsuitable for other uses. An additional 10,000 feet of sedimentary rocks, about 40 percent of which are probably water-bearing, underlie the rocks described in this report. Most of the water obtainable from these underlying rocks is probably of unacceptable quality for most purposes. 


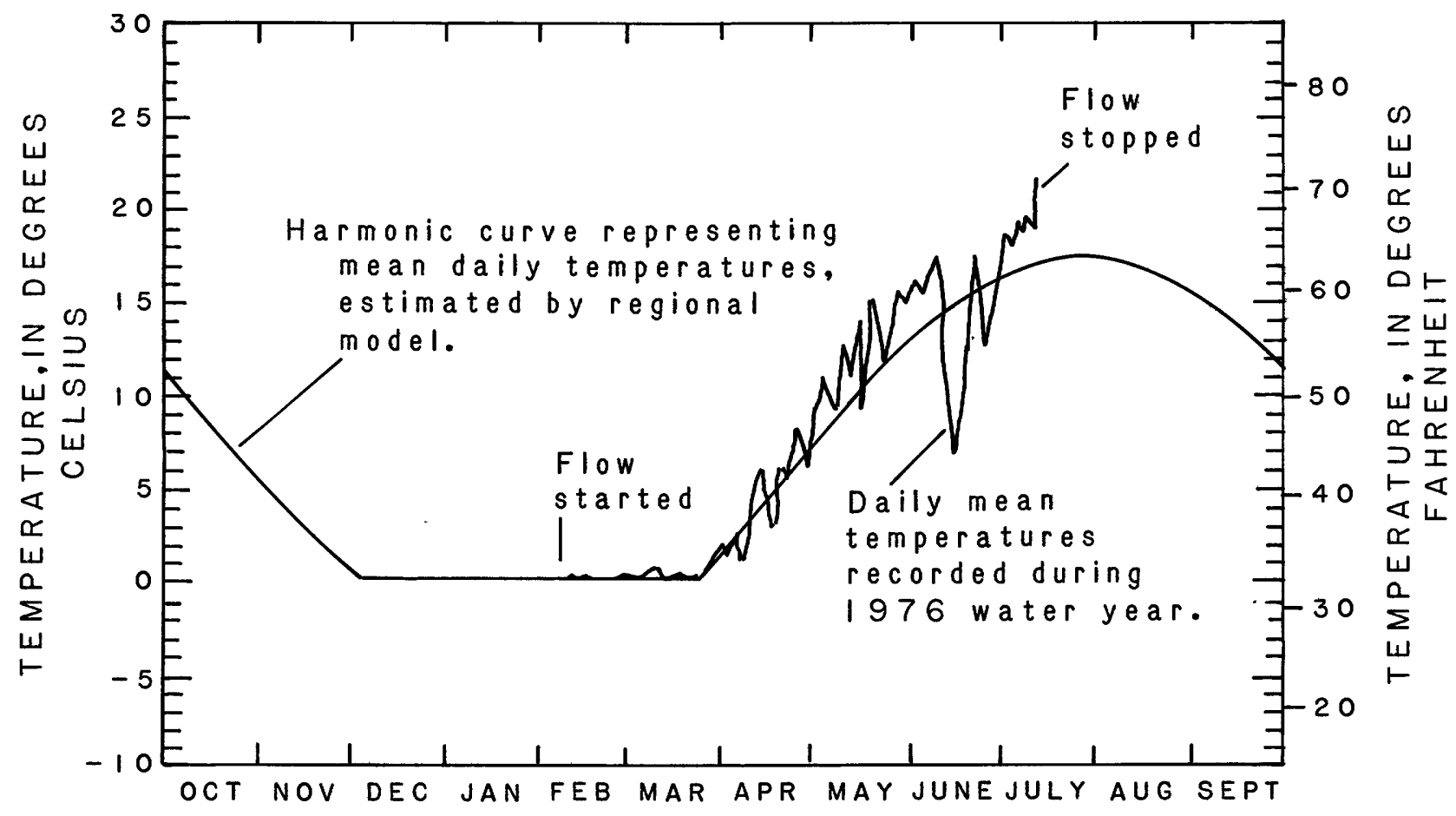

Figure 28.--Harmonic model of water temperature for upper Separation Creek at site $S-29$ shows a relation with the measured mean daily water temperature. 


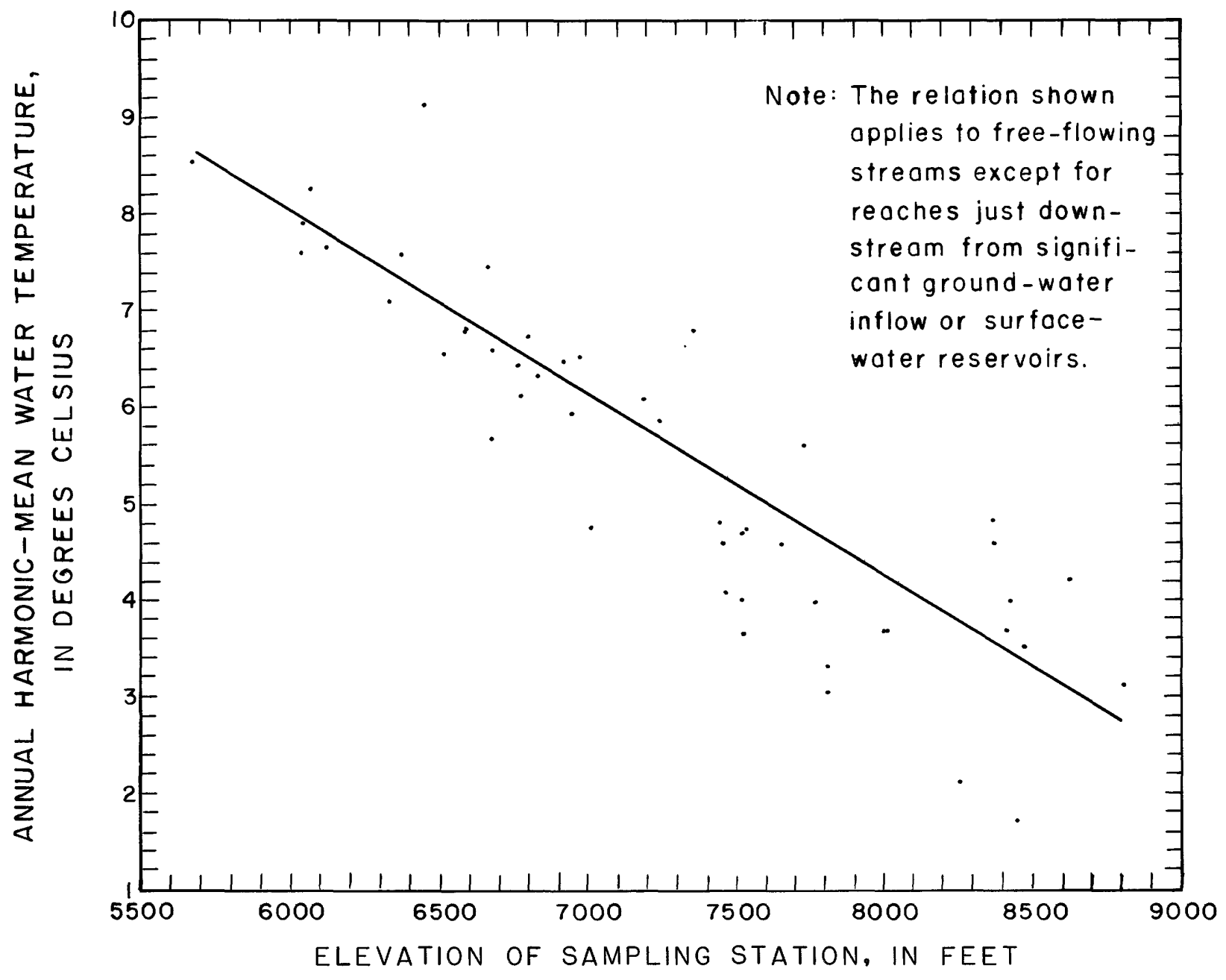

Figure 29 --Relation of elevation of sampling station to annual harmonic-mean water temperature for streams in the Green River and Great Divide Basins of Wyoming (Lowham, 1978, p. 9). 
Fifteen chemical analyses of water from 13 wells or springs in the upper Separation Creek basin are listed in table 8 . Of these, one sample is from a test wel1 augered 22 feet into the alluvium along Separation Creek, 10 samples are from 8 wells in the Fort Union Formation (2 were sampled twice), 2 samples are from springs issuing from the Lewis Shale, and 2 samples are from springs issuing from the Mesaverde Formation.

To facilitate comparison of the chemical quality of the ground water, Stiff diagrams of the analyses are plotted (figs. 30,31 ) in percent milliequivalents per liter with cations (positively charged ions) on the left side and anions (negatively charged ions) on the right side (Stiff, 1951). Thus, in the following discussion, reference to the dominance of one ion over others is based on milliequivalents. The equivalent or combining weight of an element or ion is its atomic weight or formula weight expressed in grams divided by its valence. Dividing the ionic or formula weight expressed in milligrams by the valence gives the milliequivalent weight.

Magnesium and sulfate are the dominant ions in the only sample obtained from the alluvium. The dissolved-solids concentration of this sample, $10,300 \mathrm{mg} / \mathrm{L}$, makes the water unsuitable for most purposes. However, this sample probably represents only water flowing along the base of the alluvium. Shallower alluvial water is better represented by samples collected as surface water from discontinuous reaches flowing less than $0.5 \mathrm{ft}^{3} / \mathrm{s}$ from upstream sites during the winter of 1976-77. These samples also contain magnesium and sulfate as major ions, but the dissolved-solids concentration was less than $2,000 \mathrm{mg} / \mathrm{L}$.

Most water samples from the Fort Union Formation had a dissolvedsolids concentration of less than $1,200 \mathrm{mg} / \mathrm{L}$, but a well in sec. 22, T. $21 \mathrm{~N} .$, R. $89 \mathrm{~W}$. yielded water with a dissolved-solids concentration of almost $3,000 \mathrm{mg} / \mathrm{L}$. Calcium was the dominant cation in 7 of the 10 samples; magnesium predominated in 1 sample and equaled calcium in another. Sulfate was the dominant anion in five samples and bicarbonate dominated in the other five. In 8 of the 10 samples sulfate exceeded the limit of $250 \mathrm{mg} / \mathrm{L}$ recommended for drinking water (U.S. Environmental Protection Agency, 1977).

The samples from the Lewis Shale were from springs near the contact with the underlying Mesaverde Formation, and the water probably originates in the Mesaverde. As the Lewis Shale has limited cross-bed permeability, it is probable that fractures, or possibly small unmapped faults, provide the paths for flow through the Lewis. In its contact with the Lewis shale of marine origin, the water dissolves salts that markedly change its quality. The sample from the spring in sec. 3, T. $18 \mathrm{~N}$., R. $90 \mathrm{~W}$, , had a dissolved-solids concentration of $57,700 \mathrm{mg} / \mathrm{L}$ (greater than that of sea water). Magnesium was the dominant cation and sulfate the dominant anion. The addition of this highly concentrated magnesium sulfate water to Separation Creek is a factor in changing the streamflow from a calcium bicarbonate water in the upstream reaches to a magnesium sulfate water in the downstream reaches. 


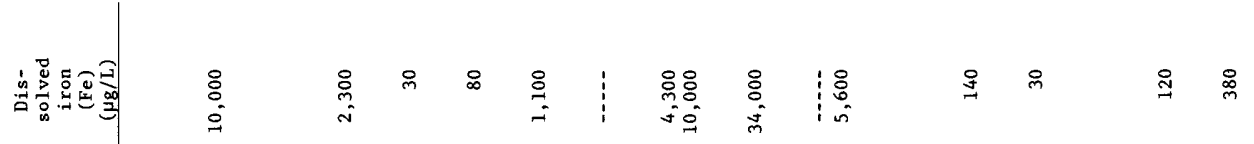

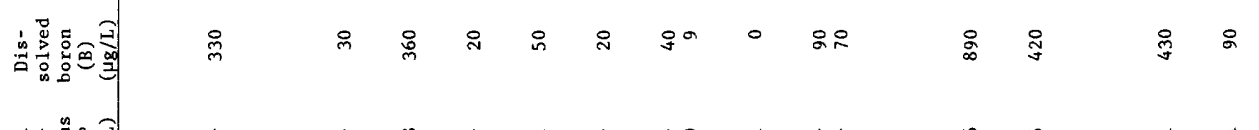

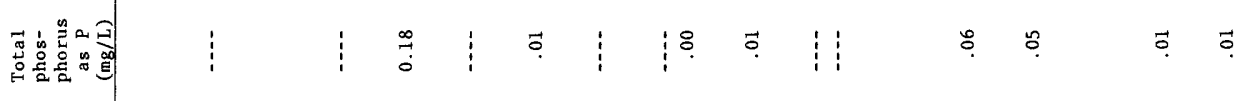

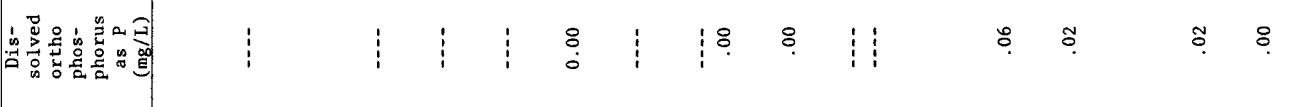

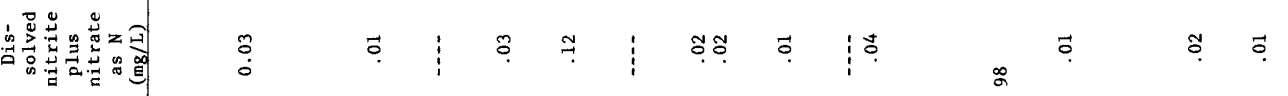

可

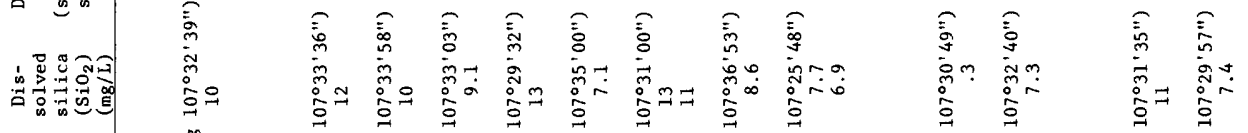

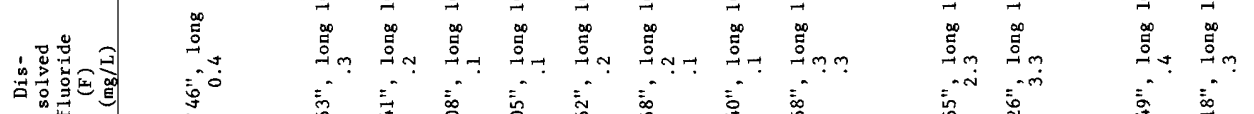

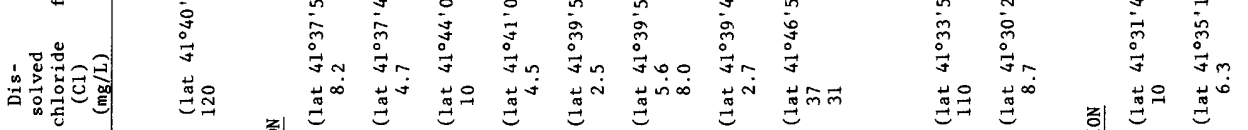

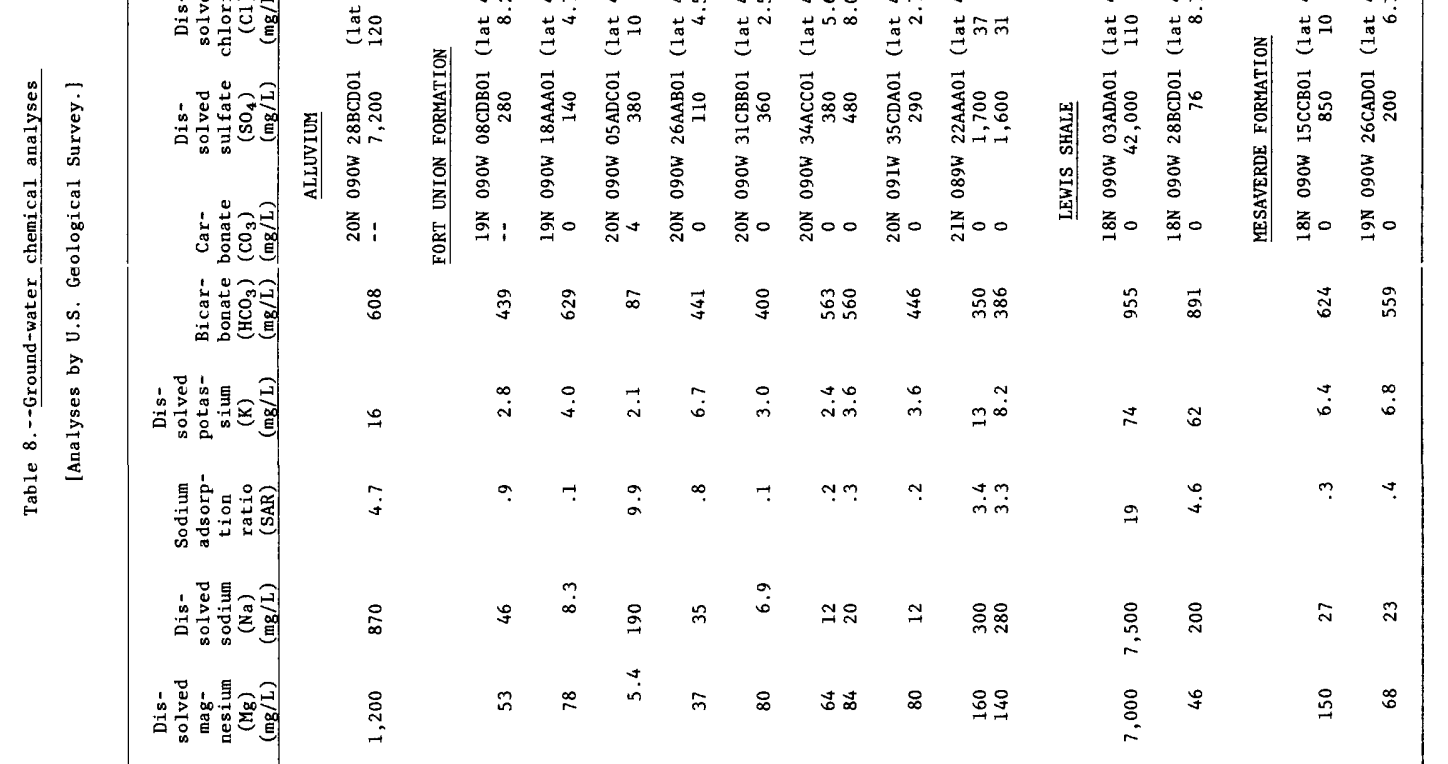

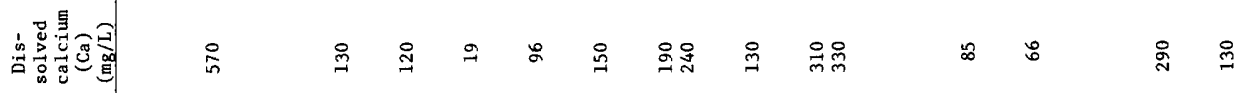

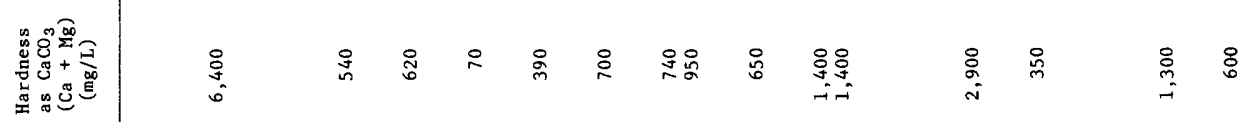

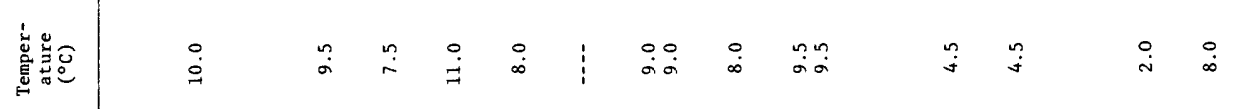

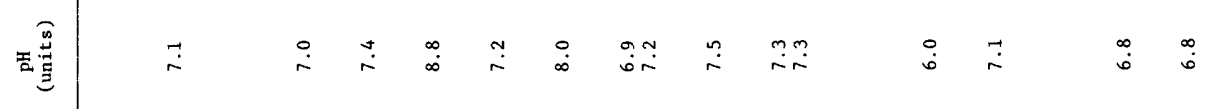

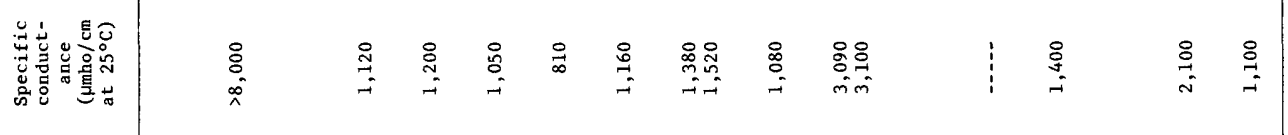

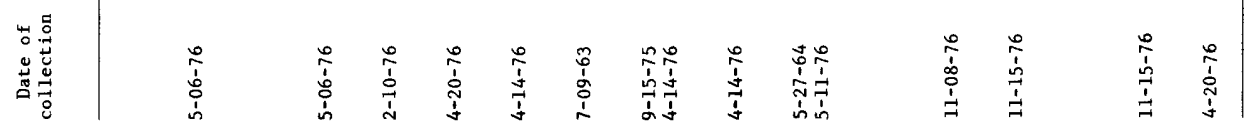




\section{Alluvium}

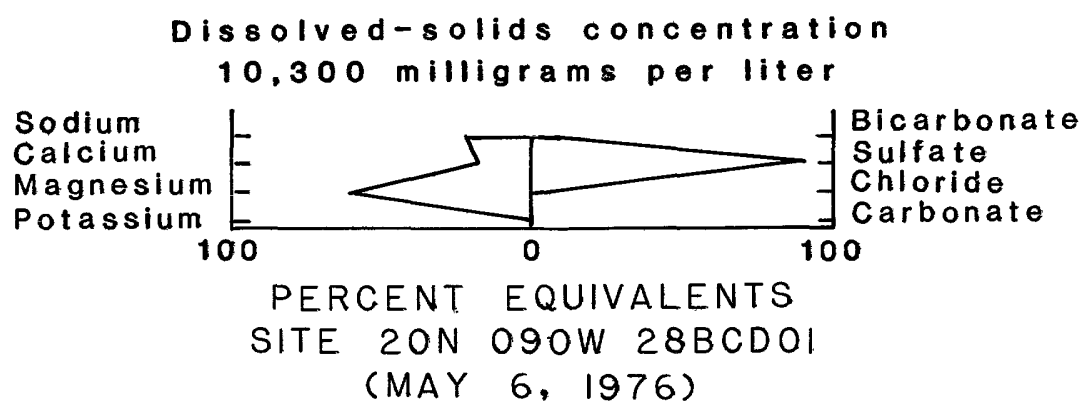

Fort Union Formation

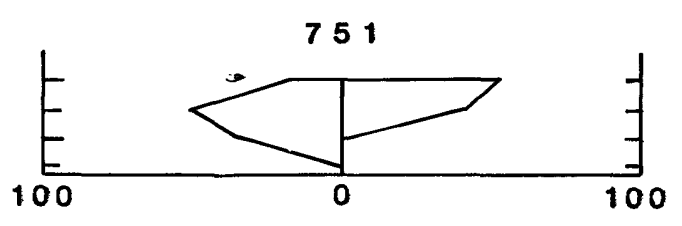

SITE 19N O9OW O8CDBOI (MAY 6, 1976)

689

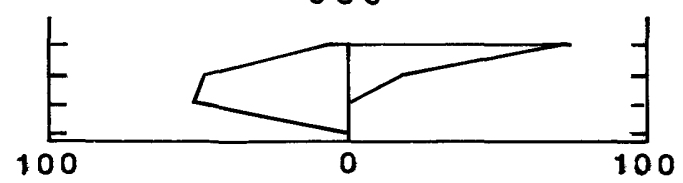

SITE I9N O9OW I8AAAOI (FEBRUARY 10, 1976)

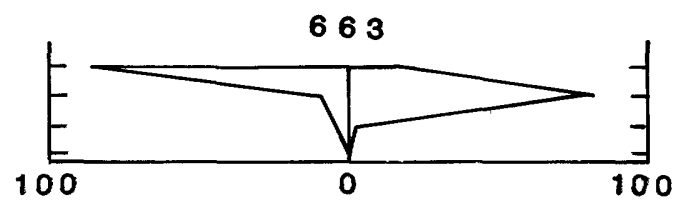

SITE $20 N$ O9OW O5DABOI (APRIL 20, 1976)
522

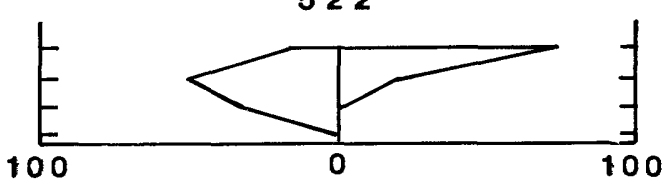

SITE 2ON O9OW 26AABOI (APRIL 14, 1976)

827

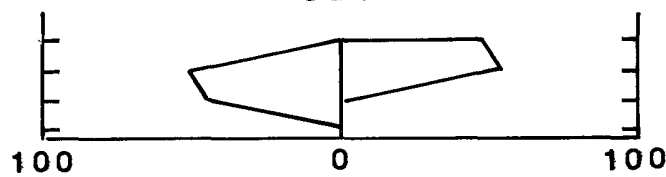
SITE $2 O N$ O9OW 3ICBBOI
(JULY 9, 1963)

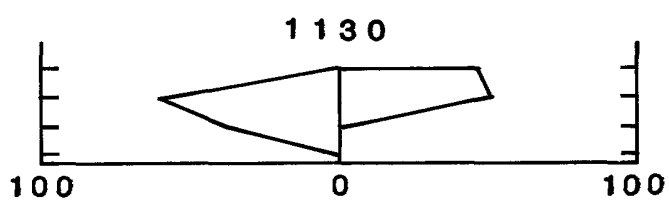

SITE 2ON O9OW 34ACCOI (APRIL 14, 1976)

Figure 30.--Stiff diagrams aid comparison of chemical analyses of water samples from alluvium and the Fort Union Formation. Sample date in parentheses. 
Fort Union Formation

Dissolved-solids concentration

783 milligrams per liter
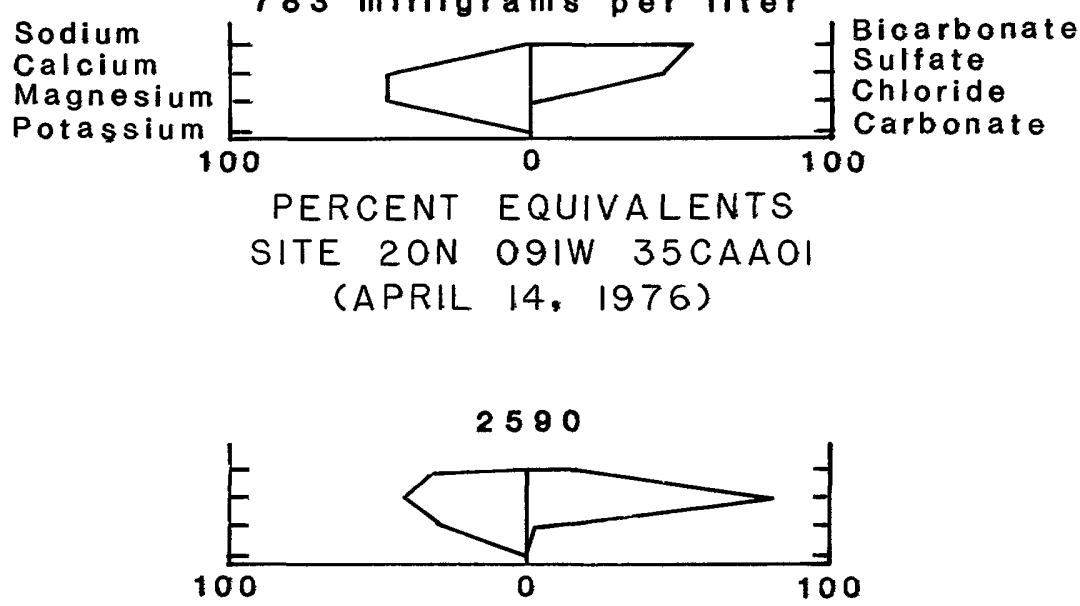

SITE 2IN O89W 22AAAOI

(MAY II, 1976)
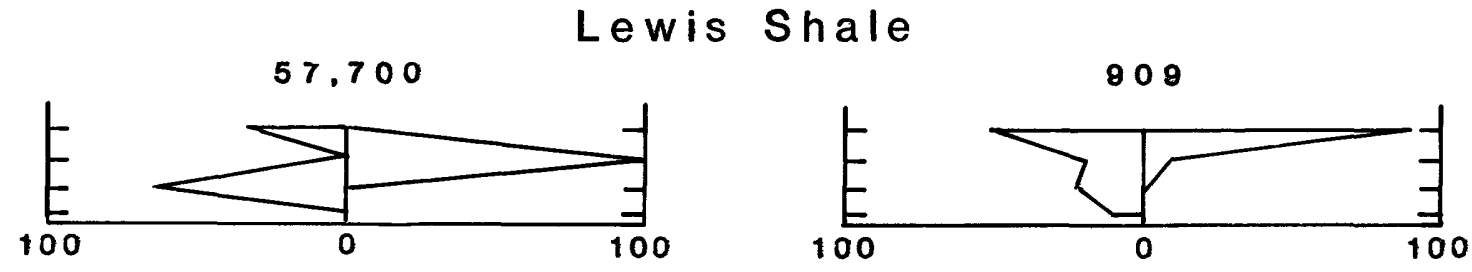

SITE I8N O9OW O3ADAOI

(NOVEMBER 8, 1976)

SITE I8N O9OW $28 B C D O \mid$
(NOVEMBER 15,1976 )

Mesaverde Formation

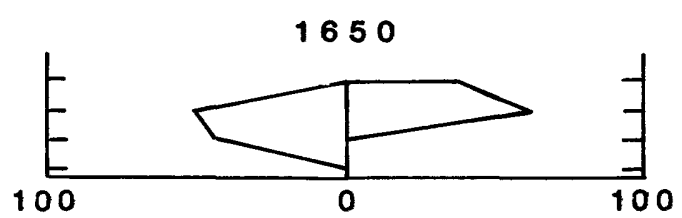

SITE I8N O9OW 15CCBOI (NOVEMBER 15,1976 )

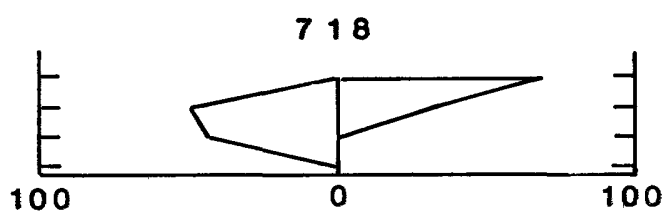

SITE I9N O9OW 26CADOI (APRIL 20, 1976)

Figure $31 .--S t i f f$ diagrams aid comparison of chemical analyses of water samples from the Fort Union Formation, Lewis Shale, and Mesaverde Formation. Sample date in parentheses. 
A similarity in percentage composition between the water from the Lewis Shale (sec. 3, T. 18 N., R. 90 W.) and the water from the basal alluvium (sec. 28, T. $20 \mathrm{~N} .$, R. $90 \mathrm{~W}$. ) is apparent from the. Stiff diagrams in figures 30 and 31. The percentage composition is similar, even though the dissolvedsolids concentration of water in the Lewis Shale is about six times that of water in the alluvium. This similarity indicates that water in the basal alluvium may be a mixture of salty water that has been diluted and slightly modified by the infiltration of fresh water as the water flowed downstream.

The spring issuing from the Lewis Shale in sec. 28, T. 18 N., R. $90 \mathrm{~W}$. is called a "sulphur" spring like several others in the vicinity because of the conspicuous odor of hydrogen-sulfide gas. This gas may be evolved by the reduction of sulfate by bacterial action fueled by organic matter in the shale. The sample contained predominantly sodium and bicarbonate ions, and its dissolved-solids concentration was relatively small ( $909 \mathrm{mg} / \mathrm{L})$. The relatively large potassium concentration in the two samples from the Lewis Shale $(74$ and $62 \mathrm{mg} / \mathrm{L})$ is derived from potassium in the shale.

Calcium ions slightly exceeded magnesium ions in concentration in the two samples from the Mesaverde Formation. Bicarbonate was a major anion but was exceeded by sulfate in the sample with the larger dissolved-solids concentration. These samples, like those from the Lewis Shale, were collected from springs near the contact between the Lewis and the Mesaverde, and the water quality may have been affected by contact with the overlying shale. The specific conductances of these two samples were 1,650 and $718 \mu$ mho. Of nine springs visited in Jep Canyon or on the flanks of Atlantic Rim, most had a specific conductance between 700 and $800 \mu \mathrm{mho}$. This indicates a dissolved-solids concentration between 450 and $550 \mathrm{mg} / \mathrm{L}$, assuming that the relationship between the specific conductance and the dissolved-solids concentration is approximately equal to that determined using the analyzed samples.

Analyses of trace metals in samples from five wells in the Fort Union Formation and one spring in the Mesaverde Formation are presented in table 9. None of the samples contained toxic concentrations of trace metals. Fluoride concentrations of the two springs issuing from the Lewis Shale were greater than drinking-water standards (table 8). Iron and manganese (table 9 ) were present in sufficient concentrations in most of the samples to be a nuisance for domestic use if untreated. Iron and manganese are dissolved in a reduced state in ground water and oxidize on contact with air or other oxidants to form an insoluble red or black precipitate. This precipitate may stain or discolor laundry, plumbing fixtures, or other objects that it contacts, or it may clog plumbing. Both iron and manganese also may impart a taste to water. The color of Red Rim may be due to oxidation of iron salts in the rock.

Four of the wells and the spring were sampled for radiochemical constituents. The results of the analyses are shown in table 10; no concentrations were greater than existing guidelines. 


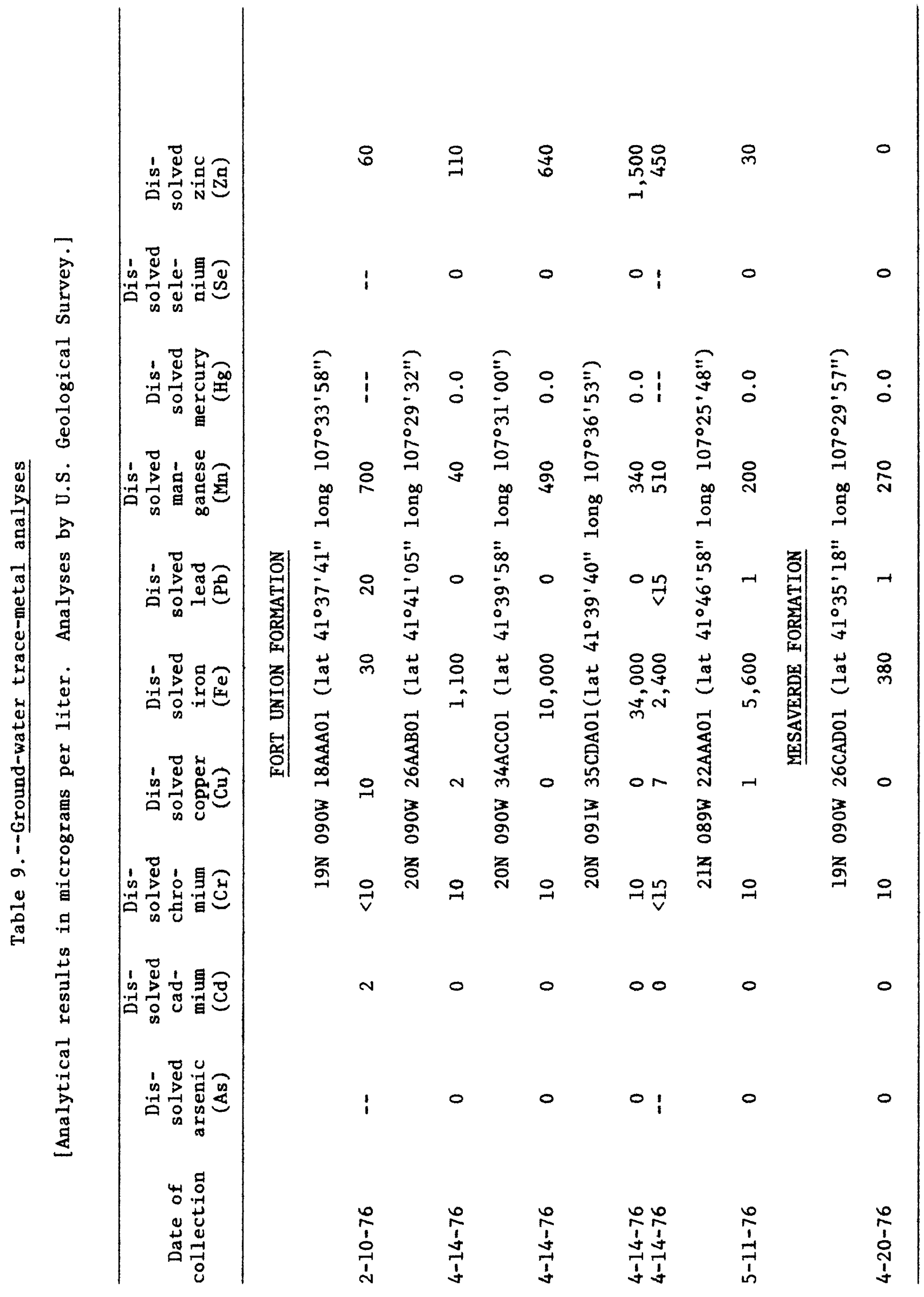




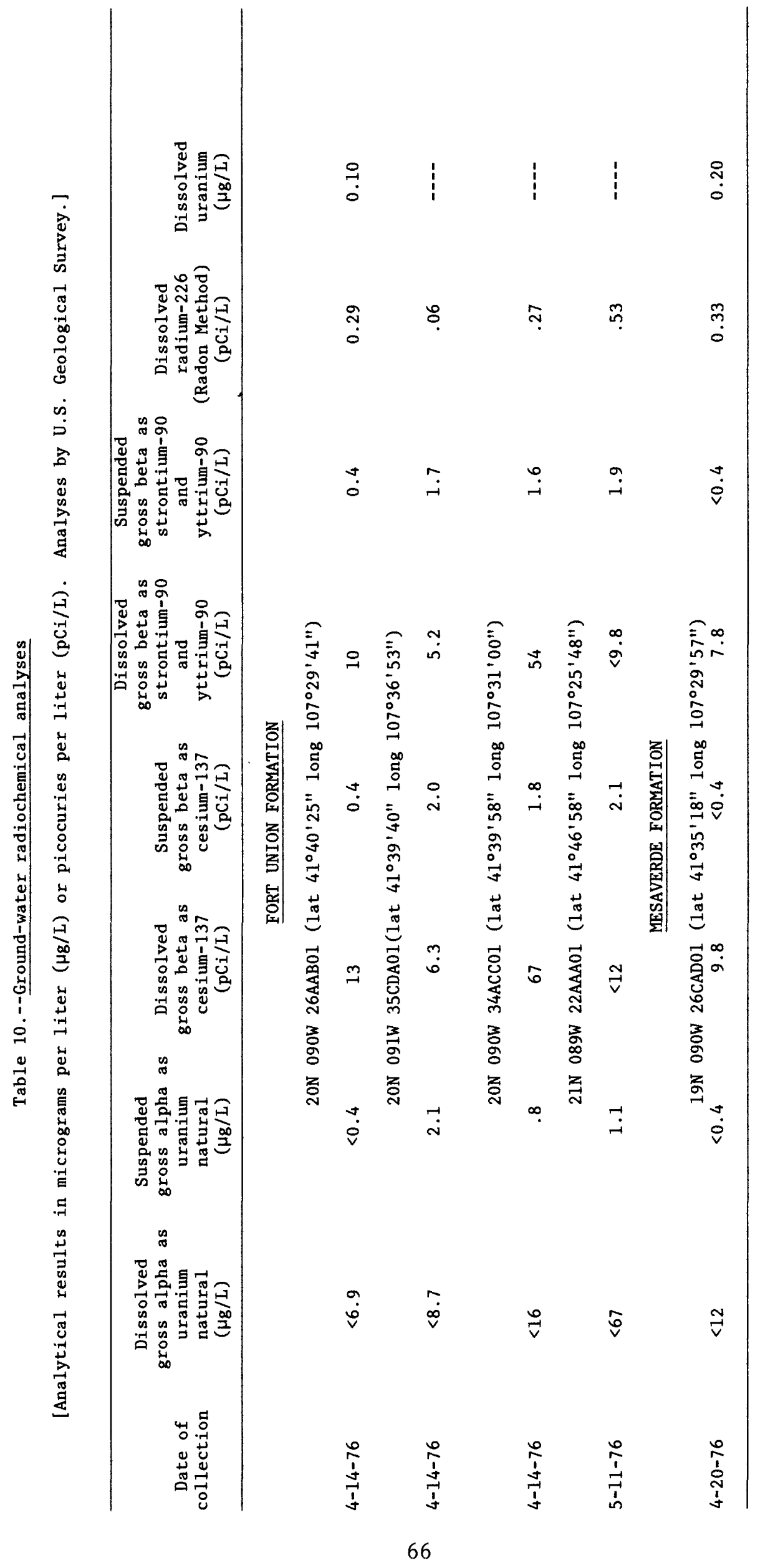




\section{SUMMARY AND CONCLUSIONS}

Snowmelt is the principal source of flow in upper Separation Creek. Streamflow in the downstream reaches of the study area (at site S-29 and downstream) normally begins in early spring and ends by midsummer. Some peak flows estimated for the creek at site $\mathrm{S}-29$ are $39 \mathrm{ft}^{3} / \mathrm{s}$ for a 2 -year flood and $420 \mathrm{ft}^{3} / \mathrm{s}$ for a 50-year flood. Estimated average annual discharge at the same site is 2,500 acre-feet. The importance of snowpack to streamflow is evident when data from the near-normal 1976 water year are compared with the 1977 water year--a year during which the snowpack was minimal. During the 1976 water year the stream runoff $(2,040$ acre-feet at site S-29) was about 10 times greater than runoff during the 1977 water year (190 acre-feet) despite the greater rainfall during 1977. The snowmelt runoff lasted three times longer during 1976, 136 days versus 45 days during 1977, as measured at site S-29. During 1976 Separation Creek flowed out of the study area. During 1977 flow from the snowmelt runoff never crossed Interstate Highway 80 . Peak flow at the gage was $39 \mathrm{ft}^{3} / \mathrm{s}$ for 1976 and $77 \mathrm{ft}^{3} / \mathrm{s}$ for 1977 . The 1976 peak resulted from snowmelt and the 1977 peak resulted from rainstorm runoff.

Ground water is the most reliable source of water in upper Separation Creek basin. Springs and windmills presently supply water to wildlife and livestock.

The Mesaverde Formation is the deepest formation likely to be an important source of water. Springs from this formation may yield as much as $35 \mathrm{gal} / \mathrm{min}$, but most yield about $4 \mathrm{gal} / \mathrm{min}$. Transmissivities estimated from slug tests ranged from 0.7 to $20\left(\mathrm{ft}^{3} / \mathrm{d}\right) / \mathrm{ft}$.

We1ls in the Fort Union Formation now provide water for livestock, but future coal mining in the formation will increase the demand for water. Well yields from this formation range from less than 1 to $325 \mathrm{gal} / \mathrm{min}$.

The dissolved-solids concentration is the most critical factor affecting Separation Creek and may be estimated from the specific conductance by using the following equation:

$$
\mathrm{DS}=0.77 \mathrm{~K}-71
$$

Specific conductance measured at site S-29 ranged from 200 to more than 2,000 Hmho. Flushing of the channel and basin surface accounts for some of the abrupt changes in the dissolved-solids concentration. The minimal snowpack during 1976-77 and smal1 spring runoff during 1977 resulted in an increase in dissolved solids. Generally, the water increased in dissolvedsolids concentration downstream. Calcium is the dominant cation in the upstream reaches, and magnesium dominates in the downstream reaches. Bicarbonate and carbonate dominate the anions in the upstream reaches, and sulfate dominates downstream.

Except for hardness and a wide range in dissolved solids, the chemical quality of upper Separation Creek is suitable for present uses--stock and wildlife watering and irrigation of native hay. The water in the upstream reaches is suitable for most uses. 
The suspended-sediment yield measured at site S-29 during 1976 was 902 tons, or 16 tons per square mile. This relatively small yield is attributed to the following: (1) Lack of rainstorms, (2) beaver dams, (3) stable channel, and (4) dense vegetal cover in the headwater area. Daily mean concentrations during 1976 ranged from 34 to $11,900 \mathrm{mg} / \mathrm{L}$. A longer record is necessary to estimate the average annual sediment yield.

The stream biota reflects the ephemeral streamflow and the stream habitat. The downstream reaches are partly repopulated from the springs and beaver ponds in the upstream reaches when flow resumes in the spring. Other biota survive by producing a resting spore, by laying drought-resistant eggs, or by aestivating when the stream dries up. A succession of dominant organisms was observed in the downstream reaches. The blue-green algae, Anabaena, with its ability to fix nitrogen from the air, proliferates in the pools when streamflow stops.

Mean daily water temperatures closely approximate mean daily air temperatures, unless the water temperature is affected by nearby spring inflow.

Ground water is generally satisfactory for its present use as livestock water. One exception is a spring issuing from the Lewis Shale that yields water with a dissolved-solids concentration greater than sea water. Water from the deepest part of the alluvium also contains relatively large concentrations of dissolved solids. Samples from 9 of 13 sites in the basin contained dissolved-solids concentrations of less than $1,000 \mathrm{mg} / \mathrm{L}$. Calcium and magnesium cations are dominant in most of the samples, making the water very hard. Sulfate and bicarbonate are the dominant anions.

\section{REFERENCES CITED}

Becker, C. F., and Alyea, J. D., 1964a, Temperature probabilities in Wyoming: University of Wyoming Agricultural Experiment Station Bulletin 415, 157 p.

1964b, Precipitation probabilities in Wyoming: University of Wyoming Agricultural Experiment Station Bulletin 416, $97 \mathrm{p}$.

Berry, D. W., 1960, Geology and ground-water resources of the Rawlins area, Carbon County, Wyoming: U.S. Geological Survey Water-Supply Paper 1458, $74 \mathrm{p}$.

Bradley, W. H., 1961, Geologic map of a part of southwestern Wyoming and adjacent states: U.S. Geological Survey Miscellaneous Geologic Investigations Map I-332.

Bruvold, W. H., 1967, Consumer assessment of mineral taste in domestic water: Journal of the American Water Works Association, v. 61, no. 11, 6 p.

Busby, M. W., 1966, Annual runoff in the conterminous United States: U.S. Geologica1 Survey Hydrologic Investigations Atlas HA-212.

Lowham, H. W., 1976, Techniques for estimating flow characteristics of Wyoming streams: U.S. Geological Survey Water-Resources Investigations $76-112,83 \mathrm{p}$.

1978, An analysis of stream temperatures, Green River Basin, Wyoming: U.S. Geological Survey Water-Resources Investigations 78-13, $41 \mathrm{p}$.

National Academy of Science, National Academy of Engineering, 1972 [1974], Water-quality criteria 1972: U.S. Government Printing Office Publicaton R3-73-033, 594 p. 
Sanders, R. B., 1974, Geologic map and coal resources of the Riner quadrangle, Carbon and Sweetwater Counties, Wyoming: U.S. Geological Survey Coal Investigations Map C-68.

Stiff, H. A., Jr., 1951, The interpretation of chemical water analysis by means of patterns: Journal Petroleum Technology, v. 3, no. 10, p. 15-17.

U.S. Bureau of Land Management, 1976, Resource and potential reclamation evaluation, Red Rim study area, Green River coal region: EMRIA Report no. 7 .

U.S. Department of Commerce, 1905-77, Climatological data; National Oceanic and Atmospheric Administration: Washington, U.S. Government Printing Office.

U.S. Environmental Protection Agency, 1975, National interim primary drinking water regulations: Federal Register, v. 40, no. 248, p. 59566-59587.

1977, National secondary drinking water regulations: Federal Register, v. 42, no. 62, p. 17143-17147

U.S. Public Health Service, 1962, Drinking water standards, 1962: U.S. Public Health Service Publication 956, 61 p.

Welder, G. E., and McGreevy, L. J., 1966, Ground-water reconnaissance of the Great Divide and Washakie Basins and some adjacent areas, southwestern Wyoming: U.S. Geological Survey Hydrologic Investigations At las HA-219. 